University at Buffalo School of Law

Digital Commons @ University at Buffalo School of Law

5-1-2019

\title{
An Empirical Examination of Agency Statutory Interpretation
}

Amy Semet

University at Buffalo School of Law

Follow this and additional works at: https://digitalcommons.law.buffalo.edu/journal_articles

Part of the Administrative Law Commons

\section{Recommended Citation}

Amy Semet, An Empirical Examination of Agency Statutory Interpretation, 103 Minn. L. Rev. 2255 (2019).

Available at: https://digitalcommons.law.buffalo.edu/journal_articles/989

C) ${ }_{\text {COPYRIGHT }}^{\text {N }}$

This Article is brought to you for free and open access by the Faculty Scholarship at Digital Commons @ University at Buffalo School of Law. It has been accepted for inclusion in Journal Articles by an authorized administrator of Digital Commons @ University at Buffalo School of Law. For more information, please contact lawscholar@buffalo.edu. 


\section{Article}

\section{An Empirical Examination of Agency Statutory Interpretation}

\section{Amy Semet ${ }^{\dagger}$}

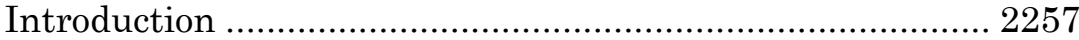

I. Statutory Interpretative Methodologies ....................... 2262

A. Background on Statutory Methods ......................... 2262

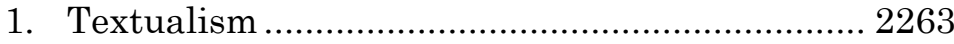

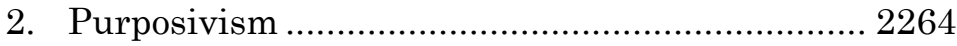

3. Substantive Canons.............................................. 2265

B. Empirical Studies of Statutory Interpretation.......... 2266

1. Statutory Analysis of Supreme Court and Federal Court Opinions...................................... 2267

2. Statutory Analysis of Administrative Law Decisions ........................................................ 2271

a. Theoretical Accounts ...................................... 2271

b. Empirical Studies of Administrative Statutory Interpretation

II. Analysis of Statutory Interpretation at the National

Labor Relations Board.

A. Background on the National Labor Relations

Board

B. Methodology of Analyzing NLRB Statutory Interpretation

$\dagger$ Postdoctoral Research Associate, Center for the Study of Democratic Politics, Princeton University. I would like to thank participants at the AALS 2017 New Voices in Legislation Conference, particularly Aaron-Andrew Bruhl and James Brudney, for their helpful comments. Participants in the 2017 Quantlaw Conference at the James E. Rogers College of Law at the University of Arizona and the 2017 Law and Society Conference offered insightful remarks. In addition, thanks to Christopher Walker for his JOTWELL post on this Article as well as Brandice Canes-Wrone for her comments. Editors at Minnesota Law Review, including Anthony Ufkin, Melanie Pulles, Clayton Carlson, Lesley Roe, Alex Park, Luke Curtis, Michelle Cardona Vinasco, Samantha Carmichel, Elizabeth Kelley, Sara Trautman, and Gina Tonn provided invaluable comments to improve the Article. Copyright (C) 2019 by Amy Semet. 
C. Overview of Results of Statutory Interpretation at the NLRB in Majority Opinions.

1. General Trends in Statutory Interpretation of Majority Opinions 2288

2. NLRB's Use of Textualism, Latin/Language, and Substantive Canons. 2288

a. Plain Meaning Textualism .......................... 2300

b. Expansionist Textualism .............................. 2301

c. Latin/Language and Substantive Canons .... 2302

3. NLRB's Use of Legislative History ...................... 2306

a. Legislative History as Limiting the Text ..... 2309

b. Legislative History as a "Plus" Factor.......... 2310

c. Legislative History as Not Foreclosing a Certain Interpretation

d. Legislative History as Irrelevant................... 2311

4. NLRB's Use of Precedent .................................... 2311

5. NLRB's Use of Policy and Practical

Considerations

a. "All Hands on Deck" Purposive Approach.... 2313

b. Balancing Policy Concerns.

6. Conclusions About NLRB Majority's Use of

Statutory Methods................................................ 2316

D. "Dueling" Statutory Interpretations ......................... 2317

1. Methodologies Used in Dissents ....................... 2318

2. Dueling Interpretations in the Majority and

Dissent .......................................................... 2320

III. How Should the Board Interpret Statutes?................... 2327

A. Pitfalls in Construing Statutes Like Courts ............ 2328

1. Use of Precedent to Hide Policymaking ............. 2328

2. Overreliance on Textual Rules........................... 2329

3. Selective Reliance on Legislative History .......... 2331

B. Proposals for Reform ............................................. 2333

1. Leverage NLRB Expertise Grounded in

Real-World Implications .................................... 2334

2. Ground Statutory Interpretation in

Substantive Background Principles .................. 2337

3. Use Rulemaking as a Tool to Advance

Key Statutory Interpretations .......................... 2338

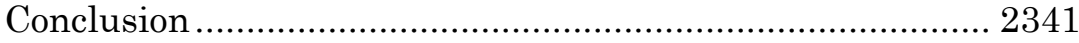




\section{INTRODUCTION}

Administrative agencies are the primary interpreters of federal statutes ${ }^{1}$ and have taken on the task of "updating" the law to reflect current conditions. ${ }^{2}$ Although scholars have advanced numerous theories on how judges in the federal courts interpret statutes, scant attention has been paid to how administrative agencies construe the statutes they are charged by Congress to interpret. Analysis of statutory interpretation beyond the realm of the federal courts is long overdue,$^{3}$ as Jerry Mashaw has observed. ${ }^{4}$ In recent years, scholars have conducted surveys concerning statutory interpretation among congressional staffers and agency personnel to provide a glimpse into the black box. ${ }^{5}$

1. See, e.g., William N. ESKRIDGE, JR. ET AL., LEGiSlation AND STATUTORY INTERPRETATION 322-23 (2d ed. 2006) ("Most government-based statutory interpretations are nowadays rendered by administrative agencies and departments, and courts are second-order interpreters . . ..”); Jerry L. Mashaw, Agency-Centered or Court-Centered Administrative Law? A Dialogue with Richard Pierce on Agency Statutory Interpretation, 59 ADMIN. L. REV. 889, 892 (2007); Jerry L. Mashaw, Norms, Practices, and the Paradox of Deference: A Preliminary Inquiry into Agency Statutory Interpretation, 57 ADMIN. L. REV. 501, 502-03 (2005); Cass Sunstein, Is Tobacco a Drug: Administrative Agencies as Common Law Courts, 47 DUKE L.J. 1013, 1055 (1998); cf. Richard J. Pierce, Jr., How Agencies Should Give Meaning to the Statutes They Administer: A Response to Mashaw and Strauss, 59 ADMIN. L. REV. 197, 200, 204-05 (2007) (arguing that agencies do not actually engage in statutory interpretation when they select among multiple interpretations of a statute; they are actually engaging in policymaking).

2. Sunstein, supra note 1, at 1053; Michael W. Spicer \& Larry D. Terry, Administrative Interpretation of Statutes: A Constitutional View on the "New World Order" of Public Administration, 56 PUB. ADMIN. REV. 38, 38 (1996).

3. For studies of statutory interpretation beyond the federal courts see Abbe R. Gluck, The States as Laboratories of Statutory Interpretation: Methodological Consensus and the New Modified Textualism, 119 YALE. L.J. 1750, 1755 (2010) (analyzing statutory interpretation in the state supreme courts); see also FrANK B. CROSS, THE THEORY AND PRACTICE OF STATUTORY INTERPRETATION 180-200 (2009) (reviewing statutory interpretation in the federal courts).

4. Mashaw argued: "[s]urely, in a legal world where agencies are of necessity the primary official interpreters of federal statutes and where that role has been judicially legitimated as presumptively controlling, attention to agencies' interpretative methodology seems more than warranted." Jerry L. Mashaw, Between Facts and Norms: Agency Statutory Interpretation as an Autonomous Enterprise, 55 U. TORONTO L. REV. 497, 497, 499 (2005) [hereinafter Mashaw, Between Facts and Norms]; see also Cass R. Sunstein \& Adrian Vermeule, Interpretation and Institutions, 101 MICH. L. REV. 885, 919 (2003) ("Precisely because the empirical study of interpretation remains in an extremely primitive state, there is every reason to think that much will be gained by further empirical efforts.").

5. See Abbe R. Gluck \& Lisa Schultz Bressman, Statutory Interpretation from the Inside-An Empirical Study of Congressional Drafting, Delegation, and the Canons: Part I, 65 STAN. L. REV. 901 (2013) [hereinafter Gluck \& Bressman, 
Several scholars also offer theoretical explanations of how agencies should interpret statutes. ${ }^{6}$ Yet, we still know little about how any one particular agency actually interprets its governing statute in its adjudications. This is particularly concerning due to Chevron' ${ }^{7}$ validation of agency statutory interpretation as an "autonomous enterprise," with appellate courts charged with ensuring that the agency's interpretation is a "reasonable" and defensible construction of the statute. ${ }^{8}$ But how do agencies arrive at their interpretations of statutes, which are entitled to deference under Cheuron? This issue is all the more relevant given recent attempts by congressional Republicans to introduce legislation that would eliminate Chevron deference, requiring courts to review agency statutory interpretations de novo. ${ }^{9}$

This Article reviews the statutory interpretation techniques employed by the National Labor Relations Board (NLRB) in the last twenty-four years through the presidencies of Bill Clinton, George W. Bush (Bush II), and Barack Obama. Discussion centers around two empirical questions: First, to what extent do Board members use statutory methods in a consistent or partisan fashion? Second, do majority and dissenting opinions "duel"

Part $I$ ] (reporting on a survey of 137 congressional staffers regarding statutory interpretation issues and the legislative process); Abbe R. Gluck \& Lisa Schultz Bressman, Statutory Interpretation from the Inside-An Empirical Study of Congressional Drafting, Delegation, and the Canons: Part 2, 66 STAN. L. REV. 725 (2013) [hereinafter Gluck \& Bressman, Part II] (continuation of Part I); Christopher J. Walker, Inside Agency Statutory Interpretation, 67 STAN. L. REV. 999 (2015) [hereinafter Walker, Inside Agency]; Christopher J. Walker, Legislating in the Shadows, 165 U. PA. L. REV. 1377 (2017) [hereinafter Walker, Legislating]; see also Adoption of Recommendations, 80 Fed. Reg. 76,161 (Dec. 16, 2015) (summarizing findings of the Administrative Conference of the United States (ACUS) regarding assistance to Congress on legislative drafting).

6. See, e.g., Aaron Saiger, Agencies' Obligation to Interpret the Statute, 69 VAND. L. REV. 1231, 1231 (2016) (arguing that an agency has an obligation to set forth the "best" interpretation of a statute); Kevin M. Stack, Purposivism in the Executive Branch: How Agencies Interpret Statutes, 109 NW. U. L. REV. 871, 876 (2015); see also Evan J. Criddle, The Constitution of Agency Statutory Interpretation, 69 VAND. L. REV. EN BANC 325, 325 (2016) (responding to Saiger piece).

7. Chevron U.S.A., Inc. v. Nat. Res. Def. Council Inc., 467 U.S. 837, 843 (1984) ("[If] the statute is silent or ambiguous with respect to the specific issue, the question for the court is whether the agency's answer is based on a permissible construction of the statute.").

8. Mashaw, Between Facts and Norms, supra note 4, at 498.

9. See Separation of Powers Restoration Act of 2016, S. 2724, 114th Cong. $\S 2$ (2016) (amending the Administrative Procedures Act (APA) to require courts to review "de novo all relevant questions of law, including the interpretation of constitutional and statutory provisions and rules"); Separation of Powers Restoration Act of 2016, H.R. 4768, 114th Cong. § 2 (2016) (same). 
with each other with respect to the statutory constructions they apply? That is, do they use contrasting methods to interpret the same statute, or do majority and dissenting opinions apply the same method to different ends? ${ }^{10}$ After exploring these questions, the Article looks at the issue normatively by asking how the Board-and administrative agencies generally-should interpret statutes.

This Article contributes to a real-world understanding of agency statutory interpretation by applying empirical analysis to demonstrate how one agency interprets its governing statute in its adjudications. This analysis reveals that Board members do not consistently use interpretive methods based on ideology. ${ }^{11}$ Majority and dissenting Board members bicker over the breath of statutory terms, invoke different parts of the statute to advance an interpretation, dispute which statute should apply, and disagree about statutory purpose. Both Democratic and Republican Board members are equally likely to apply both textualist and purposivist methods in their analysis to advance a particular policy approach. The methods the Board uses have changed over time, with the Obama Board relying more on broad pronouncements of policy goals to advance the Board's statutory mandate. The type of dueling between majority and dissenting Board members has also shifted over time; whereas during the Clinton administration, opposing sides argued over precedent differences, in more recent opinions before the Obama Board, members quarreled over whether text or policy should resolve the interpretative dilemma at hand.

The results of this analysis underscore issues worthy of further exploration regarding agency statutory interpretation. Existing theories of statutory interpretation are overly simplistic with a one size fits all methodological approach. In addition to significant substantive differences between agencies, decision makers must balance competing considerations of stability, coherence, and democratic accountability in infusing statutes with meaning. Judicial methods of interpretation should not be merely transposed onto the administrative context, as institu-

10. Anita S. Krishnakumar, Dueling Canons, 65 DUKE L.J. 909, 913 (2016).

11. See id. at 914 (finding that "none of the canons or tools seemed capable of constraining the Justices' tendency to vote consistently with their ideological preferences"). 
tional differences between statutory deciders may influence interpretive methods. ${ }^{12}$ The decider's place in the hierarchical structure, its expertise, and its democratic pedigree can all impact interpretation. ${ }^{13}$

Far too often, the unique institutional features and challenges faced by administrative agencies are ignored. For a policymaking agency charged with implementing the President's agenda, one would expect to see agencies interpreting statutes quite differently than courts. ${ }^{14}$ For instance, judges may cite precedent to infuse statutory meaning in pursuit of the twin aims of stability and coherence. But when agencies rely on precedent to the exclusion of other tools, agencies may abdicate their responsibility to be democratically accountable by failing to fully consider the practical consequences of their decisions. This result may be particularly troubling in the administrative context, where adjudication concerns real-life decisions such as social security benefits, veterans' claims, or patent rights. ${ }^{15}$ Moreover, recent studies call into question some of the assumptions underlying textual canons - such as the whole text rule, whole act rule, or the whole code rule. ${ }^{16}$ These canons are commonly employed by courts in interpreting statutes, and are also frequency used by the NLRB as this study reveals. ${ }^{17}$ But the fiction that when

12. See ADRIAN VeRMEULE, JUdGING UNDER UnCERTAINTY: AN INSTITUTIONAL THEORY OF LEGAL INTERPRETATION 213-14 (2006) (suggesting that agencies' expertise justifies wider interpretive methods than what may apply for courts); see also Aaron-Andrew P. Bruhl, Hierarchy and Heterogeneity: How to Read a Statute in a Lower Court, 97 CORNELL L. REV. 433, 434 (2012) (discussing the influence of the Supreme Court on statutory interpretation where federal courts "uncritically" apply the same interpretative doctrines); William N. Eskridge, Jr., Expanding Chevron's Domain: A Comparative Institutional Analysis of the Relative Competence of Courts and Agencies to Interpret Statutes, 2013 WIS. L. REV. 411, 420-27 (2013) (arguing that agencies' institutional position justifies a purposive approach to statutory construction); Michael Herz, Purposivism and Institutional Competence in Statutory Interpretation, 2009 MicH. ST. L. REV. 89, 94-106 (2009) (same); Mashaw, Between Facts and Norms, supra note 4 , at 504 (same).

13. Mashaw, Between Facts and Norms, supra note 4, at 504.

14. Id. at 519 .

15. Lawrence M. Solan, Precedent in Statutory Interpretation, 94 N.C. L. REV. 1165, 1165 (2016).

16. Abbe R. Gluck, Congress, Statutory Interpretation, and the Failure of Formalism: The CBO Canon and Other Ways that Courts Can Improve on What They Are Already Trying to Do, 84 U. CHI. L. REV. 177, 179 (2016) (setting forth ways in which Congress works differently than assumptions predict); see also Gluck \& Bressman, Part II, supra note 5, at 725 (finding congressional staff were unfamiliar with canons or rejected their premise).

17. Gluck \& Bressman, Part I, supra note 5, at 954. 
Congress writes statutes it speaks with a consistent and coherent voice-across and within discrete issue areas and across agencies-may be especially inapposite in the agency context, where a disjointed group of statutes, regulations, and caselaw inform how statutes are implemented. 18

These empirical findings contribute to the wider debate about how agencies should construe statutes. Karl Llewellyn challenged the view that textual canons lead decision makers to arrive at a consistent, non-ideological, and "correct" reading of the underlying statute. ${ }^{19}$ This study's findings support that claim. Board members continually switch their interpretive method depending on outcome sought.

There are many ways in which agencies can improve their interpretation of statutes. Agencies need to be more explicit in describing how they incorporate policy and practical reasoning in their statutory interpretation calculus. ${ }^{20}$ Agencies could achieve this by embracing their role as experts, or by relying more on social science data as the clear basis for agency decisions. ${ }^{21}$ The Board should more explicitly acknowledge itself as a policymaking body, as opposed to a court, in order to preserve institutional integrity and ensure the Board's statutory interpretations best effectuate its statutory mandate. ${ }^{22}$ Moreover, agencies should leverage their expertise to make decisions in accord with "background" principles" unique to the substantive area under the agency's purview. ${ }^{23}$ The NLRB should also embrace rulemaking to make decisions on some of the matters it currently leaves to case-by-case adjudication. Reliance on rulemaking to

18. Id.

19. Karl N. Llewellyn, Remarks on the Theory of Appellate Decisions and the Rules or Canons About How Statutes Are to Be Construed, 3 VAND. L. REV. 395, 401-06 (1950). Llewellyn lists twenty-eight pairs of canons and countercanons ("thrusts" and "parries"). Id.

20. See Catherine L. Fisk \& Deborah C. Malamud, The NLRB in Administrative Law Exile: Problems with Its Structure and Function and Suggestions for Reform, 58 DUKE L.J. 2013, 2019-20 (2009) (suggesting that the court of appeals and Supreme Court "review the action of all federal agencies to be more coherent and consistent in how they draw the line between law, fact, and policy").

21. Id. at 2019.

22. See Stack, supra note 6, at 887-900.

23. Jonathan R. Siegel, Guardians of the Background Principles, 2009 MICH. ST. L. REV. 123, 136 (2009) ("[T]he most important consideration in an agency's interpretation of a statute may be neither the text of the statute, nor the apparent intent or purpose behind it, but the background principles of the area of law that the agency administers."). 
advance statutory directives would be a better vehicle to balance policy coherence, stability, and democratic accountability. ${ }^{24}$

In Part I, I survey the scholarly literature. I first review the literature on statutory methodologies in Section I.A, and then in Section I.B, I situate this study within the broader scholarship concerning statutory methodologies applied specifically to the administrative state. In Part II, I turn to the empirical study at hand. I provide background on the NLRB in Section II.A and then in Section II.B, I set forth the empirical methodology employed. In Section II.C, I present and analyze the data regarding the statutory methods the Board used in its majority opinions during the twenty-four year period under study. I provide summary statistics and I also set forth different typologies on how the Board analyzed specific cases. I next turn in Section II.D to an analysis of how the statutory methods used by dissenting Board members differed from those used by the majority. I also analyze the extent to which the majority and dissent "dueled" with each other over statutory methods. Finally, I devote Part III to discussing conclusions drawn from the analysis, before making policy recommendations and proposals in Sections III.A and III.B, respectively, to inform statutory decision making for both the NLRB and administrative agencies generally. In so doing, I present a normative argument about the role that statutory methods should play in administrative decision making and I advocate that the Board embrace its policymaking role by basing its decisions explicitly on expert evidence regarding the economic effects and ramifications of its decisions. I also argue that the Board should reduce its reliance on court-centered modes of statutory interpretation and that it should more affirmatively embrace rulemaking as part of its policymaking mission.

\section{STATUTORY INTERPRETATIVE METHODOLOGIES}

\section{A. BACKGROUnd on StATUtory Methods}

Two competing theories have historically dominated the debate over how statutes should be interpreted: textualism and purposivism. Textualism advocates interpreting statutes by looking at the text's literal meaning, ${ }^{25}$ while purposivism focuses

24. See infra Part III.B.3.

25. ANTONin SCALia, A Matter of Interpretation: Federal Courts AND THE LAW 25-27 (1997). For more on textualism, see John F. Manning, Deriving Rules of Statutory Interpretation from the Constitution, 101 CoLUM. L. REV. 1648, 1648 (2001); John F. Manning, Textualism and Legislative Intent, 91 
more on interpreting the statute by looking at the overall purpose of the statutory scheme. ${ }^{26}$

\section{Textualism}

Textualism calls for judges to look at the ordinary meaning of statutory terms at the time of enactment, placing an emphasis on predictability and constancy. ${ }^{27}$ A "pure textualist" would see the statute as a "command[] from the sole politically legitimate statutory law-creating body," with the judge called "to apply that command verbatim" such that "[i]nterpretation that goes beyond statutory text operates in an extra-legal domain." 28 Textualists are generally dismissive of legislative history, ${ }^{29}$ and argue that general legislative purpose may be so "general and malleable" so as to be effectively meaningless in informing statutory meaning. 30

Textualists often rely on "textualist canons" to serve as "rules of thumb" in how to interpret the text. 31 The most common textualist canon is the "plain meaning rule" whereby the reviewing body interprets the words according to their everyday meaning. ${ }^{32}$ Other textualist canons concern the rule against superfluities so that statutes are construed to avoid redundancy and to give independent meaning to overlapping terms. ${ }^{33}$ There are also a host of Latin-named textualist canons: ejusdem generis, ${ }^{34}$

VA. L. REV. 419, 423-24 (2005); John F. Manning, Textualism and the Equity of the Statute, 101 Colum. L. REV. 1, 8-9 (2001); Caleb Nelson, A Response to Professor Manning, 91 VA. L. REV. 451, 452-53 (2005).

26. WILliam N. ESKRIDGe, JR., DYNAMIC STATUTORY INTERPRETATION 27 (1994).

27. See, e.g., SCALIA, supra note 25, at 17 (explaining textualism); W. David Slawson, Legislative History and the Need to Bring Statutory Interpretation Under the Rule of Law, 44 STAN. L. REV. 383, 413-15 (1992) (explaining textualism); David A. Strauss, Why Plain Meaning?, 72 NotRe DaMe L. REV. 1565, 1565 (1997) (explaining textualism).

28. Carlos E. Gonzalez, Reinterpreting Statutory Interpretation, 74 N.C. L. REV. 585, 595 (1996).

29. SCALIA, supra note 25 , at $16-25$.

30. ESKRIDGE, supra note 26, at 225-34.

31. John F. MANNing \& MATTHEW C. STEPHENSON, LEGislation AND REGUlATION: CASES AND MATERIALS 202 (2d ed. 2013) (noting how semantic canons "are generalizations about how the English language is conventionally used and understood, which judges may use to 'decode' statutory terms. The use of semantic canons can therefore be understood simply as a form of textual analysis").

32. Walker, Inside Agency, supra note 5, at 1023 n.103.

33. Id. at 1023.

34. Id. 
which states that when there is a list of two or more specific descriptors followed by general descriptors, the general descriptors must be restricted to the same class; 35 expressio/inclusio unius est exclusio, which states that items not on a list are impliedly assumed to be excluded; in pari materi, which states similar statutes enacted at different times of common subject matter should be interpreted in a similar way as if they were one statute; and noscitur a sociis, which states that when a word is ambiguous, one should discern its meaning by looking at references to the other terms in the list. ${ }^{36}$ Likewise, the whole act rule ${ }^{37}$ calls for reviewing courts to assume that differences in similar or parallel statutory provisions are deliberate and to presume that similar statutory provisions have consistent meaning through the statute. ${ }^{38}$ The whole code rule looks at the way courts in other cases have interpreted similar language in other statutes. ${ }^{39}$ Another variation, the whole text rule, says the "text must be construed as a whole." 40

\section{Purposivism}

In contrast to textualism, purposivism-also referred to as dynamic interpretation ${ }^{41}$ - contends that interpreters should take public values into consideration and construe statutes dynamically to reflect current social, political, and legal contexts. ${ }^{42}$ Unlike textualists, purposivists argue that judges should discern statutory meaning by first identifying the purpose of the statute

35. See, e.g., WILLIAM N. ESKRIDGE, JR., PHILIP FRICKEY \& ELIZABETH GARRETT, CASES AND MATERIALS ON LEGISLATION: STATUTES AND THE CREATION OF PUBLIC POLICY 852-54 (4th ed. 2007).

36. See, e.g., Walker, Inside Agency, supra note 5, at 1023.

37. ESKRIDGE ET AL., supra note 35, at 862-65.

38. Id. It also includes the rule that both the title and preamble of a statute can be relevant in determining statutory meaning. Id.

39. See, e.g., Deborah A. Widiss, Undermining Congressional Overrides: The Hydra Problem in Statutory Interpretation, 90 TEX. L. REV. 859, 871 (2012).

40. ANTONIN SCALIA \& BRYAN GARNER, READING LAW: THE INTERPRETATION OF LEGAL TEXTS 167 (2012).

41. Id.; see also STEPHEN BREYER, ACTIVE LIBERTY: INTERPRETING OUR DEMOCRATIC CONSTITUTION 85-101 (2005) (advancing a purposive approach).

42. See T. Alexander Aleinikoff, Updating Statutory Interpretation, 87 MiCH. L. REV. 20, 46 (1988) (“[S]tatutes ought to be responsive to today's world. They ought to be made to fit, as best they can, into the current legal landscape."); William N. Eskridge, Jr., Dynamic Statutory Interpretation, 135 U. PA. L. REV. 1479, 1479 (1987); William N. Eskridge, Jr. \& Philip P. Frickey, An Historical and Critical Introduction, in The Legal Process: Basic Problems IN THE MAKING AND APPLICATION OF LAW xci-xcii (William N. Eskridge, Jr. \& Phillip P. Frickey eds., 1994). 
and then selecting the meaning that best effectuates the stated (or implied) purpose. ${ }^{43}$ As Justice Stephen Breyer noted, "overemphasis on text can lead courts astray, divorcing law from life-indeed, creating law that harms those whom Congress meant to help." 44

Purposivism has its limitations. A statute may have multiple and cross-cutting purposes, making it difficult to discern a clear statutory purpose..$^{45}$ In addition, legislative history may not always be a reliable guide to discerning statutory purpose. ${ }^{46}$

\section{Substantive Canons}

Substantive canons are judicially-created "rules of thumb" based on overriding legal norms, policies, and conventions. ${ }^{47}$ All told, there are more than 100 substantive canons. ${ }^{48}$ For instance, the "rule of lenity" dictates that any ambiguity be resolved in favor of the defendant. 49 The oddly named "charming Betsy" doctrine states that national statutes be construed so as to not conflict with international law. ${ }^{50}$ Other canons suggest that statutes be interpreted so as to not violate so-called "fundamental values," or so as to not abrogate sovereign immunity, or not to preempt state law. ${ }^{51}$ The constitutional avoidance states that a

43. Eskridge \& Frickey, supra note 42 , at xcii.

44. BREYER, supra note 41 , at 85.

45. See, e.g., Fisk \& Malamud, supra note 20, at 2020 (noting multiple purposes of labor law).

46. ESKRIDGE, supra note 26, at 27 ("[I]dentifying the actual or even conventional purpose of a statute is just as difficult as identifying the actual or conventional intent of the legislature, or perhaps even more so, since legislators may have incentives to obscure the real purposes of the statute.").

47. ESKRIDGE ET AL., supra note 35, at 934-35 (examining the use of dueling canons of construction in Supreme Court majority and dissenting opinions); Henry M. Hart, JR. \& Albert M. Sacks, The Legal Process: Basic ProbLEMS IN THE MAKING AND APPLICATION OF LAW 1376 (William N. Eskridge, Jr. \& Philip P. Frickey eds., 1994) (noting that substantive canons "promote objectives of the legal system which transcend the wishes of any particular session of the legislature"); MANNING \& STEPHENSON, supra note 31, at 247 ("[S]ubstantive canons do not purport to be neutral formalizations of background understandings about the way people use and understand the English language. Instead, these substantive canons ask interpreters to put a thumb on a scale in favor of some value or policy that courts have identified as worthy of special protection.").

48. Gluck \& Bressman, Part I, supra note 5, at 940.

49. Id. at 946 .

50. Charming Betsy Canon Law and Legal Definition, USLEGAL, https:// definitions.uslegal.com/c/charming-betsy-canon (last visited Mar. 25, 2019).

51. Walker, Inside Agency, supra note 5, at 1005. 
statute should be read to avoid a "serious question" of constitutionality ${ }^{52}$ while the legislative acquiescence canons deems Congress to have agreed to an interpretation when Congress did not modify it or not otherwise respond. ${ }^{53}$ Clear statement rules requires Congress to not interpret a statute in a given way unless Congress made clear its intent for a given result. 54

\section{B. EMPIRICAL STUDIES OF STATUTORY INTERPRETATION}

The empirical-oriented scholarship analyzing statutory methods falls into two camps. ${ }^{55}$ Traditionally, scholars focus their empirical study on how the Supreme Court interprets statutes. ${ }^{56}$ Recently, scholars have shifted the focus beyond the Supreme Court to assess in a quantitative fashion how federal courts and administrative agencies interpret statutes. ${ }^{57}$ Some investigate how administrative agencies interpret statutes through the use of surveys of congressional staff and administrators, ${ }^{58}$ while others embark on a more qualitative analysis of agency-specific statutory interpretations, picking out a few examples of actual cases to illustrate given points. ${ }^{59}$ No study has yet merged the various lines of inquiry to examine how administrative agencies use statutory methods in their day-to-day decision making in any sort of systematic way.

52. Gluck \& Bressman, Part I, supra note 5, at 947-48.

53. Nina A. Mendelson, Change, Creation, and Unpredictability in Statutory Interpretation: Interpretive Canon Use in the Roberts Court's First Decade, 117 MICH. L. REV. 71, 91 (2018).

54. Gluck \& Bressman, Part I, supra note 5, at 942-43.

55. See, e.g., James J. Brudney \& Corey Ditslear, Canons of Construction and the Elusive Quest for Neutral Reasoning, 58 VAND. L. REV. 1, 4 (2005); David S. Law \& David Zaring, Law Versus Ideology: The Supreme Court and the Use of Legislative History, 51 WM. \& MARY L. REV. 1653, 1654 (2010); Nicholas S. Zeppos, The Use of Authority in Statutory Interpretation: An Empirical Analysis, 70 TEX. L. REV. 1073, 1074-75 (1992).

56. See Krishnakumar, supra note 10, at 934 (examining the use of dueling canons of construction in Supreme Court majority and dissenting opinions).

57. See, e.g., Gluck \& Bressman, Part I \& Part II, supra note 5; Walker, Inside Agency, supra note 5.

58. See Gluck \& Bressman, Part I \& Part II, supra note 5 (conducting surveys amongst congressional staffers); see also Walker, Inside Agency, supra note 5 (conducting surveys amongst agency staffers).

59. See, e.g., Daniel P. O'Gorman, Construing the National Labor Relations Act: The NLRB and Methods of Statutory Construction, 81 TEMP. L. REV. 178, 178 (2009) (providing examples of how the National Labor Relations Board (NLRB) interprets statutes and offering theories for how the Board should interpret statutes). 
1. Statutory Analysis of Supreme Court and Federal Court Opinions

There are many excellent studies of statutory analysis of decisions at the Supreme Court and the federal courts. Much of this analysis focuses on empirically examining how the Chevron doctrine works. William Eskridge and Lauren Bauer compiled a comprehensive dataset of Supreme Court decisions involving a statutory interpretation issue between the time Chevron was decided in 1984 and the end of 2005.60 They find no evidence to indicate when the Court will invoke particular deference regimes in whether to defer to the agency. ${ }^{61}$ In the wake of the Eskridge and Bauer analysis, there have been many follow-up studies studying how federal courts apply Chevron. ${ }^{62}$

In addition to the Chevron-inspired literature, another strain of the literature looks at how federal judges use tools of statutory construction, such as textual and substantive canons and legislative history. Frank Cross conducted a study measuring judges' use of tools of statutory construction to assess how those sources constrain judges from reaching outcomes inapposite to what one would predict from looking at their political

60. William N. Eskridge, Jr. \& Lauren E. Baer, The Continuum of Deference: Supreme Court Treatment of Agency Statutory Interpretations from Chevron to Hamdan, 96 GEO. L.J. 1083, 1083 (2008). The dataset consists of 1014 cases. Id. For other empirical studies, see Thomas W. Merrill, Judicial Deference to Executive Precedent, 101 YALE L.J. 969 (1992); Thomas J. Miles \& Cass R. Sunstein, Do Judges Make Regulatory Policy-An Empirical Investigation of Chevron, 73 U. CHI. L. REV. 823 (2006); Connor R. Raso \& William N. Eskridge, Jr., Chevron as a Canon, Not a Precedent: An Empirical Study of What Motivates Justices in Agency Deference Cases, 110 CoLUM. L. REV. 1727 (2010). For studies at the court of appeals, see Kent Barnett \& Christopher J. Walker, Chevron in the Circuit Courts, 116 MICH. L. REV. 1 (2017); Lisa Schultz Bressman, How Mead Has Muddled Judicial Review of Agency Action, 58 VAND. L. REV. 1443 (2005); Kristin E. Hickman \& Matthew D. Krueger, In Search of the Modern Skidmore Standard, 107 ColuM. L. REV. 1235 (2007); Orin S. Kerr, Shedding Light on Chevron: An Empirical Study of the Chevron Doctrine in the U.S. Courts of Appeals, 15 YALE J. REG. 1 (1998); Peter H. Schuck \& E. Donald Elliot, To the Chevron Station: An Empirical Study of Federal Administrative Law, 1990 DUKE L.J. 984 (1990).

61. See Eskridge \& Baer, supra note 60, at 1091.

62. See, e.g., Kerr, supra note 60 , at 32 (finding that courts upheld regulations at a rate of $58 \%$ in the year after Chevron to $82 \% 2-4$ years after Chevron then back to $72 \%$ ); Miles \& Sunstein, supra note 60 , at 849 (noting validation rates); Schuck \& Elliott, supra note 60 at 1039 (noting affirmance rate of $71 \%$ in $1984,81 \%$ in 1986 , then $75 \%$ in 1988); see also Reuel E. Schiller, The Era of Deference: Courts, Expertise, and the Emergence of New Deal Administrative Law, 106 MicH. L. REV. 399, 436-37 (2007) (noting circuit court deference to NLRB decisions regarding statements made by employees during union elections). 
background. Cross concludes that legislative history is more constraining than plain meaning. ${ }^{63} \mathrm{He}$ also finds a marked increase in the use of pragmatism by federal judges analyzing statutes in the circuit courts. ${ }^{64}$ Cross also discovers a distinct increase in the use of linguistic canons between 1990 and 2000, a period that corresponds to a time when the use of legislative history was on the decline. ${ }^{65}$

Other studies look specifically at interpretive canons, and in particular, analyze rates of dueling canons in majority and dissenting opinions. One study of workplace cases, by James Brudney and Corey Ditslear, looks at interpretive canons in every Supreme Court decision in workplace matters from 19692003.66 In the limited subject matter studied, they notably find no relationship between ideology and the canons employed by a justice, concluding that "in divided decisions, the Justices themselves are more prone to view the canons as reasonably amenable to supporting either side." 67 They discover that conservative justices tend to use canons to reach conservative outcomes, while liberal justices often use the same canon to reach a liberal result. ${ }^{68}$ In follow-up work, they narrow their claim, finding that liberal justices are more likely to vote in favor of the employer when using legislative history but that the use of canons and legislative history by conservatives is more mixed. ${ }^{69}$

Another study by David Law and David Zaring analyzes the use of legislative history in Supreme Court cases from 19532006. ${ }^{70}$ Law and Zaring find that dissenting judges are more likely to cite legislative history when a majority opinion also cites legislative history, suggesting that judges are sensitive to their colleagues' arguments. ${ }^{71}$ Nina Mendolson undertakes an

63. CROss, supra note 3 , at $160-77$.

64. Id. at 189 .

65. Id. at 190 .

66. Brudney \& Ditslear, supra note 55, at 1 (showing little constraint by linguistic and substantive canons); see also James J. Brudney \& Corey Ditslear, Liberal Justices' Reliance on Legislative History: Principle, Strategy, and the Scalia Effect, 29 BERKELEY J. EMP. \& LAB. L. 117, 117 (2008) (looking at constraining effects of legislative history on workplace cases); James J. Brudney \& Corey Ditslear, The Warp and Woof of Statutory Interpretation: Comparing Supreme Court Approaches in Tax Law and Workplace Law, 58 DUKE L.J. 1231, 1231 (2009) (showing use of legislative history).

67. Brudney \& Ditslear, supra note 55, at 1.

68. Id.

69. $I d$.

70. Law \& Zaring, supra note 55, at 1738.

71. Id. 
empirical study of statutory canons used by the Roberts Court from October 2004 through October 2014. ${ }^{72}$ She finds that except for recently appointed Justice Neil Gorsuch, all the Justices apply at least one canon in their authored statutory interpretation cases. ${ }^{73}$ She also finds that the Court continually creates new canons, that they are not applied in reliable fashion, and that there is a "mismatch" between canons actually used by the Court and those not accepted by congressional staff. 74

Other scholars analyze statutory decisions in both majority and dissenting opinions. Anita Krishnakumar did two empirical analyses of Supreme Court statutory interpretation. In one article, she analyzes the role that "dueling canons" play in Supreme Court decisions in the Roberts Court from 2005 through $2010 .{ }^{75}$ She finds that conservative justices use the canons to reach conservative outcomes in about $60 \%$ of cases, with liberal justices using those same canons to reach liberal outcomes. ${ }^{76}$ She also finds that the canons do not constrain the judges to vote against their ideology and that practical reasoning led to greater rates of dueling between the majority and the dissent than traditional methods of construction. ${ }^{77}$ Krishnakumar also looks more thoroughly at the Roberts Court's use of substantive canons, finding that they are infrequently invoked as a justification in statutory construction. ${ }^{78}$ Rather, she uncovers that Supreme Court precedent as well as reliance on practical considerations serve as the "real gap-filling interpretive tools" that the Court relies on. ${ }^{79}$

More recently, Lawrence Solan explores the use of precedent in guiding statutory decisions. ${ }^{80}$ Examining the use of precedent in split five to three or five to four decisions before the Supreme Court, Solan paints a "chaotic picture" of the use of precedent in statutory interpretation. ${ }^{81}$ He concludes that judges on opposing

72. Mendelson, supra note 53, at 77 (stating that the Supreme Court frequently uses canons to interpret cases).

73. Id. at 71 .

74. Id. at $78-79$.

75. Krishnakumar, supra note 10 , at 909.

76. Id.

77. Id

78. Anita S. Krishnakumar, Reconsidering Substantive Canons, 84 U. CHI. L. REV. 825, 825 (2017).

79. Id. at 887 .

80. Solan, supra note 15 , at 1172 .

81. Id. at 1173. 
sides cite contrasting precedent, or strategically cite precedent to advance their preferred outcome. ${ }^{82}$

Other scholars compare and contrast statutory methods vertically. Aaron-Allen Bruhl undertakes a comparative analysis using a "matching corpus" method to compare and contrast the statutory methodologies used by federal courts at three levels of the judicial hierarchy: district court, circuit court, and the Supreme Court. ${ }^{83}$ He concludes that statutory methodologies differ at each level of the judicial hierarchy, with some methods (such as the federalism canon) being more frequently used at the $\mathrm{Su}$ preme Court while other tools (such as invoking the presumption against jurisdiction) being more often employed by district courts. ${ }^{84}$ Overall, district court, he notes, use "simpler" interpretive methods and take Chevron more seriously than the Supreme Court. ${ }^{85} \mathrm{He}$ concludes that lower courts use all tools of statutory interpretation less often than the Supreme Court, other than precedent. 86

James Brudney and Lawrence Baum also employ a matching corpus method to compare the use of dictionaries and legislative history between the courts of appeals and the Supreme Court in three doctrinal areas: criminal law, business and commercial law, and labor and employment law. 87 They find that courts of appeals rely far less on legislative history and dictionaries than the Supreme Court does. ${ }^{88}$ Courts also use legislative history in different ways, with circuit courts using it to resolve ambiguities, confirm meaning, or reveal legislative intent, while the Supreme Court relies on legislative history to shed light on historical changes in the statutory text. ${ }^{89}$ Brudney and Baum

82. Id.

83. Aaron-Andrew P. Bruhl, Statutory Interpretation and the Rest of the Iceberg: Divergences Between the Lower Federal Courts and the Supreme Court, 68 DUKE L.J. 1, 3 (2018) [hereinafter Bruhl, Statutory Interpretation]; see also Aaron-Andrew P. Bruhl, Communicating the Canons: How Lower Courts React When the Supreme Court Changes the Rules of Statutory Interpretation, 100 MiNN. L. REV. 481 (2015) (studying federal courts of appeals' reactions).

84. Bruhl, Statutory Interpretation, supra note 83, at 3-4, 56.

85. Id. at 56

86. Id. at 60 .

87. James J. Brudney \& Lawrence Baum, Protean Statutory Interpretation in the Courts of Appeals, 58 WM. \& MARY L. REV. 681, 681 (2017).

88. Id. at 682 .

89. Id. In addition, the Supreme Court relies more on "vertical" legislative history (changes to the text over time) while appellate courts look more to committee reports. $I d$. at $688-89$. 
surmise that these differences in approach are due to political and institutional factors. ${ }^{90}$

Scholars have also begun to study statutory interpretation focused exclusively on the lower federal courts. Abbe Gluck and Judge Posner survey forty-two federal judges to get a sense of the statutory methods they employ. ${ }^{91}$ Instead of finding that textualism or purposivism drives the debate, they describe the dominant mode as "intentional eclecticism," with all judges employing both traditionally textualist and purposive methods. ${ }^{92}$ They also find that age and past experience working on Capitol Hill influence how judges approach interpreting statutes. ${ }^{93}$ Older judges see themselves more as legal institutionalists, viewing statutory interpretation in terms of delegation. ${ }^{94}$ Judges who had experience working in the federal government, particularly those who worked on Capitol Hill, are less likely to buy into some of the interpretive canons concerning unwarranted fictions about how Congress actually works in practice. ${ }^{95}$

\section{Statutory Analysis of Administrative Law Decisions}

\section{a. Theoretical Accounts}

Scholars have offered several recommendations for agency statutory interpretation. Jerry Mashaw and Peter Strauss argue that agencies should not necessarily be expected to construe statutes in the same way that courts do. ${ }^{96}$ Mashaw sets forth normative guidelines for how an agency should interpret a statute differently than a court as a result of its unique constitutional role and practical necessity. ${ }^{97} \mathrm{He}$ contends we might expect agencies to "energize" a statutory program and engage in more activist

90. Id. at 687. The heightened exposure of the Supreme Court to media and the wider political arena prompt them to rely more on dictionaries to "deflect charges of judicial activism." Id.

91. Abbe Gluck \& Richard Posner, Statutory Interpretation on the Bench: A Survey of Forty-Two Judges on the Federal Courts of Appeals, 131 HARV. L. REV. 1298, 1300 (2018).

92. Id. at 1302 .

93. Id. at 1303 .

94. Id. at $1303-04$.

95. Id. at 1304 .

96. Mashaw, Between Facts and Norms, supra note 4, at 519; Peter L. Strauss, When the Judge Is Not the Primary Official with Responsibility to Read: Agency Interpretation and the Problem of Legislative History, 66 CHI.-KENT L. REV. 321, 328-329 (1990).

97. Mashaw, Between Facts and Norms, supra note 4, at 501. 
policymaking in line with political principals. ${ }^{98}$ Mashaw also argues that unlike courts-who are more constrained by norms like stare decisis and who seek to impose coherence on the legal order-agencies need not always be consistent in how they interpret statutes. ${ }^{99}$ Instead, agencies should be cognizant of political realities. ${ }^{100}$

Strauss also argues that "agencies essentially live the process of statutory interpretation," and that the political nature of the task of interpretation takes on a special role in the context of agency statutory interpretation. ${ }^{101}$ Agencies, much more so than courts, are able to use legislative history to greater effect. ${ }^{102}$ As Strauss notes, "[t]he enduring and multifaceted character of the agency's relationship with Congress contributes to the agency's capacity to distinguish reliably those considerations that served to shape the legislation, the legislative history wheat, from the more manipulative chaff."103 Agencies' special "institutional memory" provides agencies with a unique perspective and a "critical resource[]" from which to discern congressional intent. 104

More recently, Kevin Stack argues that agencies "are purposive by statutory design." 105 Stack suggests that agencies' expertise, political accountability, and ability to effectively evaluate and vet proposals makes them uniquely capable of interpreting statutes in a purposivist way by looking at the purpose of the regulatory scheme and selecting actions that best effectuate those purposes. ${ }^{106}$ He further contends that, because agencies are guided by an "intelligible principle," agencies have a duty to (1) develop an understanding of that purpose; (2) evaluate alternatives for action in relation to the purpose; (3) act in ways that best further that purpose; and (4) adopt only interpretations of statutes that effectuate that purpose. ${ }^{107}$

Aaron Saiger too argues that agencies interpreting regulations have an ethical obligation to espouse what the agency

\footnotetext{
98. Id. at 507 .

99. Id. at 503-05.

100. Id.

101. Strauss, supra note 96 , at 329.

102. Id. at $346-48$.

103. Id. at 347 .

104. Mashaw, Between Facts and Norms, supra note 4, at 508 (discussing Strauss, supra note 96).

105. Stack, supra note 6 , at 876 .

106. Id. at 871 .

107. Id. at $875-76$.
} 
deems to be the "best" interpretation of the statute. ${ }^{108} \mathrm{He}$ contends that it is wrong for agencies to advance a statutory interpretation that solely advances its policy preferences; rather it must use "interpretive criteria" to arrive at the "best" interpretation of the statute, even if such interpretation departs from those preferences. ${ }^{109}$ In particular, when a court defers to an agency, it is incumbent on the agency to "say what the law is," a responsibility akin to that of a court. ${ }^{110}$

\section{b. Empirical Studies of Administrative Statutory Interpretation}

In recent years, a few detailed and comprehensive empirical studies have been done looking at how Congress and administrative agencies embark on statutory interpretation. Abbe Gluck and Lisa Bressman conducted a comprehensive study of agency interpretive practices by surveying members of Congress. ${ }^{111}$ They surveyed 137 congressional staffers with 171 questions to inquire into what members of Congress involved in drafting thought of agency practices. ${ }^{112}$ The study is one of the largest empirical studies related to statutory interpretation, and the only empirical analysis of congressional staffer opinions regarding legislative history, Chevron, Mead, Skidmore, and other core elements of statutory interpretation. ${ }^{113}$ They find that legislative drafters are unfamiliar with the names of certain doctrines, but they still incorporate the assumptions of those doctrines in how they draft legislation. ${ }^{114}$ The Gluck and Bressman survey finds some canons to be out of favor; for instance, congressional respondents seemed to reject the rule against superfluities and the whole code rule. ${ }^{115}$ Survey respondents said that legislative history is the most important interpretive tool after the text. ${ }^{116}$

108. Saiger, supra note 6 , at 1232 .

109. Id. (emphasis omitted).

110. Id. at 1234 (quoting Marbury v. Madison, 5 U.S. (1 Cranch) 137, 17778 (1803)).

111. Gluck \& Bressman, Part I, supra note 5, at 905-06. The Gluck and Bressman study was preceded by a smaller study done by Victoria Nourse and Jane Schacter. See Victoria F. Nourse \& Jane S. Schacter, The Politics of Legislative Drafting: A Congressional Case Study, 77 N.Y.U. L. REV. 575 (2002).

112. Gluck \& Bressman, Part I, supra note 5, at 905-06.

113. Id. at 909 (noting that "there has been almost no other empirical research of this kind"); $i d$. at 927-28 figs. $1 \& 2$.

114. Id. at 907 .

115. Id. at 933-37.

116. Id. at 907; see Walker, Inside Agency, supra note 5, at 1040 (noting that, 
Two recent surveys have looked at the role agencies play in legislative drafting. Christopher Walker, in conjunction with the Administrative Conference of the United States (ACUS), conducted a comprehensive survey of agency rule drafters at seven executive departments and two independent agencies to shed light on the approaches that agency rule drafters use when they interpret statutes and draft regulations. ${ }^{117} \mathrm{He}$ finds that drafters believe the canons to be the "key indicia of interpreter fidelity" and that rule drafters are frequently familiar with the canons, even by the Latin names. ${ }^{118}$ His respondents note that they frequently use canons such as noscitur a sociis and ejusdem generis as well as the whole act rule, but that they do not often use the whole code rule or in pari materia. ${ }^{119}$ Moreover, only a little more than half of the respondents report that the assumptions behind expressio unius and the rule against superfluities are often or always true. ${ }^{120}$ Walker reaches many of the same conclusions as Gluck and Bressman, though there are some differences. ${ }^{121}$ For instance, his survey finds legislative history to be an important aid to interpretation, though, in contrast to the congressional drafters in the Gluck and Bressman study, agency decision makers are less likely to believe legislative history is used to facilitate political deals. ${ }^{122}$ Walker also details how agencies provide "technical drafting assistance" to Congress, underscoring how agencies play an "active- . . yet opaque" role in devising the governing statutory scheme. ${ }^{123}$

Like Walker, Jarrod Shobe debunks long-standing assumptions of legislative drafting, concluding that agencies often play a large role $a$ priori in legislative drafting. ${ }^{124} \mathrm{He}$ surveys fiftyfour agency officials who reveal that agencies participate in the drafting process such that Congress and the agency agree ex ante

\footnotetext{
in the Gluck and Bressman study, 93\% of agency rule drafters said that legislative history helps explain the purpose of the statute).

117. Walker, Inside Agency, supra note 5, at 1003-04.

118. Id. at 1004 .

119. Id.

120. Id. at 1028 .

121. Gluck and Bressman, for instance, find less support for expressio unius, and classified the rule against superfluities as a canon that was known but rejected, while Walker categorizes these canons as "concepts probably in use." Id.; Gluck \& Bressman, Part I, supra note 5, at 932 fig.4, 932-36.

122. Inside Agency, supra note 5, at 1041 fig.7.

123. Walker, Legislating, supra note 5, at 1377.

124. Jarrod Shobe, Agencies as Legislators: An Empirical Study of the Role of Agencies in the Legislative Process, 85 GEO. WASH. L. REV. 451, 451 (2017).
} 
on statutory meaning. ${ }^{125}$ Shobe also details how agencies work collaboratively with Congress throughout the drafting process, with agencies frequently offering extensive changes to legislative texts. ${ }^{126}$ The results of Shobe's survey, much like Walker's, reveal a drafting process that is a lot more fragmented than commonly thought, with agencies being intimately involved in legislative drafting and often providing samples of statutory text to overseeing congressional committees. ${ }^{127}$

\section{ANALYSIS OF STATUTORY INTERPRETATION AT THE NATIONAL LABOR RELATIONS BOARD}

In this Part, I analyze how one specific agency-the NLRBinterprets statutes over a twenty-four-year period. I first provide background on the NLRB in Section II.A. Then, in Section II.B, I set forth the methodology employed as well as how the data was collected. In Section II.C, I present summary statistics on my findings and I also offer a conceptual framework setting forth what I see as separate typologies of how the NLRB interprets statutes in its majority decisions. I turn in Section II.D to look at how dissenters on the Board "duel" with the majority in how they interpret statutes.

\section{A. BACKGROUND ON THE NATIONAL LABOR RELATIONS BOARD}

In 1935, Congress enacted the National Labor Relations Act (NLRA), also known as the Wagner Act, to protect employees' rights to organize and bargain collectively. ${ }^{128}$ Congress created the NLRA in an attempt to (1) reduce strikes and industrial strife which had burdened commerce, and (2) increase employee bargaining power, which could have the effect of raising wages at the height of the Great Depression. ${ }^{129}$ During the New Deal era, the NLRB was one among many new administrative agencies created to handle the responsibilities of a burgeoning administrative state. ${ }^{130}$ Judicial decisions weakening union power had

125. Id. at 515 .

126. Id. at 455 .

127. Id. at 451, 465-66.

128. See National Labor Relations (Wagner) Act, Pub. L. No. 74-198, 49 Stat. 449 (1935) (codified as amended at 29 U.S.C. $\S \S 151-69$ ).

129. See National Labor Relations Act, Pub. L. No. 74-198, § 3, 49 Stat. 449 (codified as amended at 29 U.S.C. § 151) (describing the purpose of the Act); see also IRVING Bernstein, The NeW DEAL Collective BARGAINING Policy 90 (1950) (noting the two-fold purpose "to voice an economic philosophy and to lay a constitutional foundation for the Act").

130. Paul R. Verkuil, The Purposes and Limits of Independent Agencies, 
caused many to be fearful of using courts as a vehicle to combat labor abuses, so Congress created an administrative agency to handle disputes as an alternative to courts. ${ }^{131}$ As such, Congress deliberately designed the Board to both prosecute NLRB cases as well as to supervise union elections. ${ }^{132}$ As reflected in the Act's legislative history, Senator Robert Wagner, architect of the NLRA, intended the Board to be a non-partisan tribunal that would make decisions detached from the whims of changing administrations. 133 The new Board differed from its predecessor, the National Labor Board, which was an arbitral body composed of two members each from labor and industry, with a final seat for a representative of the public interest. ${ }^{134}$ Appointments in the first half-century reflected this spirit with many appointees rising from academia or government. ${ }^{135}$ Despite efforts by the Department of Labor to include the Board within its purview, Congress created the Board as an independent agency so as to provide some degree of insulation from political influence. 136 Creators of the Board wanted a body that would be flexible enough to respond to changing circumstances while at the same

1988 DUKE L.J. 257, 257 (noting that the NLRB was one of many administrative agencies created during the New Deal era).

131. Michael J. Hayes, After 'Hiding the Ball' Is Over: How the NLRB Must Change Its Approach to Decision-Making, 33 RUTGERS L.J. 523, 554 (2002) ("[I]n passing the [NLRA], Congress continued the process of diminishing the role of courts in the labor area by creating an alternative to the courts ...."); Ralph K. Winters, Jr., Judicial Review of Agency Decisions: The Labor Board and the Court, 1968 SUP. CT. REV. 53, 59 n.5 (1968) ("The creation of the Board, therefore, may fairly be viewed as the result of congressional dissatisfaction with judicial lawmaking in the area of labor law.").

132. 29 U.S.C. $§ 153$ (2012).

133. 1 NLRB, LEGISLATIVE HistoRy OF THE NATIONAL LABOR RELATIONS ACT OF 1935, at 1428 (1949) (noting Senator Robert Wagner stating “[f] or years lawyers and economists have pleaded for a dignified administrative tribunal, detached from any particular administration that happens to be in power, and entitled to deal quasi-judicially with issues with which the courts have neither the time nor the special facilities to cope").

134. Joan Flynn, A Quiet Revolution at the Labor Board: The Transformation of the NLRB, 1935-2000, 61 OHIO ST. L.J. 1361, 1363 (2000).

135. See, e.g., JAMES A. Gross, The MAKing OF THE NATiOnAL LABor RelATIONS BOARD 150 (1974) (noting that one of the NLRB's first chairmen was a professor of law with "little knowledge of either labor relations or labor law"); JAMEs A. GRoss, THE RESHAPING OF THE NATIONAL LABOR RELATIONS BOARD: NATIONAL LABOR POLICY IN TRANSITION 1937-1947, at 226 (1981) [hereinafter GROSS, RESHAPING] (describing the appointment of an "economics professor and former Resolution 44 NLRB member").

136. See GROSS, RESHAPING, supra note 135, at 227 (describing the political independence created in the NLRB by the Wagner Act in freeing it from federal regulation and making it independent of the Department of Labor). 
time responsive to political overseers. 137 The NLRA's legislative history indicates that Congress intended for Board member terms to be short and for turnover to be rapid so as to ensure responsiveness. ${ }^{138}$

After widespread labor strife and claims by opponents that the NLRB ruled too much in a pro-labor fashion, Congress amended the Wagner Act in 1947 through the Taft-Hartley amendments with new provisions to combat union abuses, among other changes. ${ }^{139}$ The NRLA has an inconsistent mandate in that its statutory underpinnings represent an "odd marriage" between the Wagner Act and the Taft-Hartley Act. ${ }^{140}$ The Act itself is a reflection of different standards and operates somewhat at cross-purposes. As Catherine Fisk and Deborah Malamud question, "How radically pro-union was the Wagner Act, and how radically anti-union was Taft-Hartley"? ${ }^{141}$ Some labor scholars contend that the Wagner Act was a "transformative, pro-union, pro-collective bargaining 'super statute," while the Taft Hartley Act was merely an amendment to reduce the power of unions and NLRB abuses of power, but it did not fundamentally alter the liberal basis of the Wagner Act."142 Other scholars see Taft-Hartley as altering the pro-union bent of the Wagner Act by significantly changing the power of the Board. ${ }^{143}$

In addition to expanding the reach of unfair labor charges to include unions in addition to employers, the Taft-Hartley Act increased the size of the Board and created an Office of General

137. Samuel Estreicher, Policy Oscillation at the Labor Board: A Plea for Rulemaking, 37 ADMIN. L. REV. 163, 167 (1985).

138. For instance, legislators thought that expanding the term to five years would prevent Board members "from being subject to immediate political reactions at elections." O'Gorman, supra note 59, at 189.

139. Labor Management Relations (Taft-Hartley) Act, Pub. L. No. 80-101, 61 Stat. 136 (1947) (codified at 29 U.S.C. $\$ \S 141-44$ ).

140. Fisk \& Malamud, supra note 20, at 2036.

141. Id. at 2034.

142. William N. Eskridge, Jr. \& John Ferejohn, Super-Statutes, 50 DUKE L.J. 1215, 1227 (2001) (using the NLRB as an example of a super-statute); Fisk $\&$ Malamud, supra note 20, at 2034.

143. Archibald Cox, Some Aspects of the Labor Management Relations Act, 61 HARV. L. REV. 274, 274 (1947) (arguing that Taft-Hartley "appears to reject the policy of encouraging the spread of collective bargaining, [and] accepts the institution where it already exists"); see Cynthia L. Estlund, The Ossification of American Labor Law, 102 COLUM. L. REV. 1527, 1533-35 (2002) (noting that the Taft-Hartley Act set back the labor movement and arguing that the TaftHartley amendments work "largely by addition, not subtractions; they left the core provisions of the original New Deal text ... essentially intact"); Fisk \& Malamud, supra note 20, at 2034. 
Counsel in order to separate adjudicative from prosecutorial functions - a unique feature of the NLRB among federal agencies. ${ }^{144}$ The President appoints members for staggered five year terms "with the advice and consent of the Senate."145 Although early Board members largely hailed from academia or the government, more recent appointees come from labor and management backgrounds. ${ }^{146}$

Unlike many other agencies, the NLRB proceeds primarily through adjudication in its policymaking, only engaging in rulemaking in a few instances in its seventy-five year history. ${ }^{147}$ The General Counsel brings unfair labor practice cases in a regionbased system, where they are heard before an Administrative Law Judge (ALJ). ${ }^{148}$ The Board, sitting in randomly assigned three-member panels, hears appeals of ALJ decisions if any party files an "exception" to the ALJ opinion. ${ }^{149}$ Three-member Board decisions are free from the constraints of stare decisis, ${ }^{150}$ although the full five-member Board can hear and decide cases

144. Labor Management Relations Act of 1947, ch. 120, 61 Stat. 136 (1947) (codified at 29 U.S.C. $\$ \S 141-187$ ). Unlike other agencies, the Board has an independent General Counsel, who is appointed by the President, and who is separate from the Board, with adjudicatory and prosecutor functions being divided. $I d$.

145. 29 U.S.C. $§ 153($ a) (2012). The Taft-Hartley Act of 1947 expanded the Board from three to five members. Id.

146. Flynn, supra note 134, at 1364-65.

147. See Estreicher, supra note 137, at 174-75 (noting that the Board uses adjudication to make policy as opposed to rulemaking); Joan Flynn, The Costs and Benefits of "Hiding the Ball": NLRB Policymaking and the Failure of Judicial Review, 75 B.U. L. REV. 387, 391 (1995) (finding that NLRB did only one substantive rulemaking over sixty years). NLRB has faced criticism of its failure to use rulemaking, with critics contending that an adjudicatory approach results in the Board frequently changing policies. Id. at 392.

148. Administrative Law Judge Decisions, NLRB, https://www.nlrb.gov/ cases-decisions/decisions/administrative-law-judge-decisions (last visited Mar. $25,2019)$ (explaining “[a]n administrative law judge's decision is not binding legal precedent in other cases unless it has been adopted by the Board on review of exceptions").

149. Robert A. Gorman \& MatThew W. Finkin, Basic TeXt on Labor LAW: UNIONIZATION AND COLLECTIVE BARGAINING 11-12 (2d ed. 2004) (noting procedures). Less than $1 \%$ of administrative law judge ("ALJ") decisions ever reach the Board as most cases are resolved by a regional hearing officer on or before they are heard by ALJs, who are bound by Board precedent in issuing their decisions. Flynn, supra note 147, at 426 n.165.

150. GORMAN \& FINKIN, supra note 149, at 11-12; Claire Tuck, Policy Formulation at the NLRB: A Viable Alternative to Notice and Comment Rulemaking, 27 CARDOZO L. REV. 1117, 1137-38 n.162 (2005) (noting role of General Counsel). 
en banc, which are then binding upon future NLRB adjudications. ${ }^{151}$ A party losing before the Board can seek relief in the federal appellate courts, although the Board largely subscribes to the doctrine of nonacquiescence whereby it rejects the precedential value of federal courts of appeals decisions in order to ensure uniform application of law throughout the country. 152 The Board's orders are not self-enforcing; unless the parties voluntarily agree to abide by the Board's orders, the General Counsel must go to federal court to seek enforcement. ${ }^{153}$ Only $1 \%$ of cases are appealed. ${ }^{154}$

Unlike most other agencies, the NLRB primarily has only one statute to interpret-the NLRA. ${ }^{155}$ Polarization and partisanship has inhibited substantial revisions to the NLRA, and as a result the law has not been amended in any major way since 1974. ${ }^{156}$ Because of this, the NLRB does not have to engage in much new statutory interpretation because it routinely reviews the same statute in each adjudication. The NLRB hears two main types of cases: (1) unfair labor practice allegations against employers or unions, ${ }^{157}$ and (2) election representation cases or bargaining unit determinations. ${ }^{158}$ The first type, unfair labor practice disputes, are claims that some entity (usually an employer) has violated the unfair labor practice provisions of the NLRA. ${ }^{159}$ Examples of unfair labor practice violations include

151. Winters, supra note 131, at 63.

152. Samuel Estreicher \& Richard L. Revesz, Nonacquiescence by Federal Administrative Agencies, 98 YALE L.J. 679, 681 (1989); Flynn, supra note 147, at 421 (noting that the General Counsel does not look to circuit precedent in deciding whether or not to issue a complaint); Rebecca Hanner White, Time for a New Approach: Why the Judiciary Should Disregard the "Law of the Circuit" When Confronting Nonacquiescence by the National Labor Relations Board, 69 N.C. L. REV. 639, 639-40 (1991) (same).

153. Losing parties can seek judicial review of an adverse Board decision in the federal court where they petition for relief or seek enforcement of a Board order. 29 U.S.C. § 160(i)-(f) (2012). The General Counsel can also seek enforcement of a Board order. Id. Parties can file appeals "wherein such person resides or transacts business" or in the D.C. Circuit. Id. § 160(f).

154. Flynn, supra note 147, at 426 n. 165 .

155. 29 U.S.C. $\S 153$ (creating the NLRB to carry out the policies set forth in the National Labor Relations Act (NLRA)).

156. Estlund, supra note 143, at 1530. The last major change was in 1959. See Labor-Management Reporting \& Disclosure (Landrum-Griffin) Act of 1959,

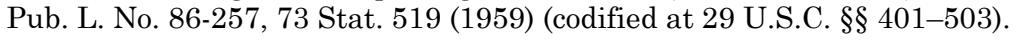

157. 29 U.S.C. $\S 160$.

158. Id. § 159 .

159. Id. $\S 160$. 
discharging an employee for engaging in union activity, unilaterally altering the terms and conditions of a union contract, or refusing to bargain with the union in "good faith." 160 Unfair labor disputes are not limited to actions against employers (so-called "CA" cases), although disputes against employers represent the vast majority of cases heard by the Board. ${ }^{161}$ A party can also bring a claim against a union for unfair labor practices ("CB," "CC," "CD," "CE," or "CG" cases). ${ }^{162}$ In addition to unfair labor practice disputes, the Board hears disputes related to union elections and representation petitions, such as cases about certifying the appropriate bargaining unit or other aspects of the election process. 163

Board voting is highly ideological, with Republican members routinely voting in favor of management and Democratic members voting in favor of labor in the majority of adjudications. ${ }^{164}$ Often, the Board reverses many of the decisions of the prior administration when a new partisan majority takes gains control of the Board. ${ }^{165}$ Critics of the Board commonly cite these frequent flip-flops as cause for concern because they undermine the stability of labor law. ${ }^{166}$ The ideological nature of appointments to the Board since the Reagan years has exacerbated this instability. ${ }^{167}$ Former Board member William Gould argues that

160. Id. § 158(a)(1)-(5).

161. Amy Semet, Political Decision Making at the National Labor Relations Board: An Empirical Examination of the Board's Unfair Labor Practice Decisions Through the Clinton and Bush II Years, 37 BERKELEY J. EMP. \& LAB. L. 223, 245 (2016).

162. 29 U.S.C. $\S 158(\mathrm{~b})$.

163. Id. § 159(i).

164. See, e.g., William N. Cooke \& Frederick H. Gautschi III, Political Bias in NLRB Unfair Labor Practice Decisions, 35 INDUS. \& LAB. REL. REV. 539, 549 (1982) (finding that the presidential appointment process has a major impact on the Board's voting patterns); Fisk \& Malamud, supra note 20, at 2020 (noting that "[a]cross a range of doctrinal arenas, it is apparent that Bush II labor policy made a decisive shift in favor of protecting managerial prerogative and augmenting the ability of employers and employees to oppose unionization"); Flynn, supra note 134, at 1411 (noting the partisan-based voting patterns); Ronald Turner, Ideological Voting on the National Labor Relations Board, 8 U. PA. LAB. \& EMP. L. 707, 712 (2006) (noting the predictive value of ideology in votes at the Board).

165. Tuck, supra note 150, at 1153 (noting how after there is a change in presidential administration, resulting in new Board members, the Board often reverses many of the precedents made by the prior Board).

166. Cooke \& Gautschi, supra note 164, at 549 (noting how the inconsistency and ambiguity that plagues Board's decisions can hinder labor management relations).

167. Flynn, supra note 134, at 1366. Changes in the appointment process 
the nomination process, characterized by "batching" nominees together for congressional approval, has exacerbated the partisanship at the Board.168 Today, there is an informal tradition of appointing both Democrats and Republicans to the Board, while ensuring that the President's party maintains a three to two majority and that a member from the President's party chairs the Board. ${ }^{169}$ At the turn of the twenty-first century, the Board consisted of two ex-management lawyers, two former union lawyers, a former law professor, and a career Board employee-exactly the type of Board Congress expressly rejected when designing the NLRB. ${ }^{170}$

\section{B. METhodology of ANALYZING NLRB STATUTORY INTERPRETATION}

To analyze how the Board interprets statutes, I first created a dataset consisting of the cases in which the Board engages in statutory interpretation of the NLRA. The Board, in some respects, engages in statutory interpretation every time it adjudicates a case; it must decide whether any given fact scenario fits within the violations set forth by the NLRA. Most of these cases, however, fit into predictable fact patterns that the Board can easily resolve by applying precedent. As such, I limit the analysis to only those few cases in which the Board can fairly be said to

over the years-including the rise of "packaged" appointments where groups of nominees for different governmental posts are "packaged" together for a Senate vote- exacerbated the trend of a more partisan nomination process. Id. at 1367 . Indeed, with one exception, all of President Clinton's appointees have been packaged nominations. Administration Faces Possibility of Four Vacancies, No Quorum, at NLRB, 1997 Daily Lab. Rep. (BNA) No. 202, at A-8 (Oct. 20, 1997) (noting that Clinton had to make recess appointments to keep the agency up and running).

168. William B. Gould IV, Politics and the Effect on the National Labor Relations Board's Adjudicative and Rulemaking Processes, 64 EMORY L.J. 1501, 1526 (2015); see Gillian E. Metzger, Agencies, Polarization, and the States, 115 CoLUM. L. REV. 1739, 1762, 1762 n.112 (2015) (noting how insiders composed many of the appointments).

169. See Estreicher, supra note 137, at 170 (noting how the Board's lawmaking is often seen as "unstable"); Tuck, supra note 150, at 1118 (arguing that the Board's flip-flops "undermine[] the stability, certainty and efficiency of . . policies ... because neither party can rely on Board precedent"); Turner, supra note 164, at 714 ("As a matter of custom, and not law, no more than three of the five NLRB members may belong to the President's political party.").

170. Turner, supra note 164, at 764 (listing experience of Board members in the Appendix). 
engage in statutory interpretation as a matter of first impression, as opposed to simply applying an established rule to new factual circumstances.

This dataset includes NLRB cases through the Clinton, Bush II, and Obama Administrations. The dataset includes NLRB cases decided between 1993 through the end of the Obama administration in January 2017. In all, I reviewed more than 7000 cases to discern cases involving statutory interpretation. ${ }^{171}$ When reading each case, I coded the statutory methodology employed. I also performed a word search to capture all cases in which the Board engaged in statutory interpretation, and I similarly looked at all NLRB appellate cases that discussed either Chevron or statutory interpretation. ${ }^{172}$

I find that the Board engages in some measure of statutory interpretation in less than $2 \%$ of all cases during the indicated time frame; in most instances, it simply applies existing caselaw. This finding is unsurprising. As Fish and Malamud note, a large proportion of the Board's decisions do not rely on any specific statutory language, a result of the lack of any recent legislative activity. 173 Moreover, there is no "helpful" legislative history as the Supreme Court's statutory interpretation in NLRB cases "often turns on nothing more than statements about the underlying purposes of the statute, and shows the same incapacity the Board manifests when it comes to how to prioritize Wagner Act versus Taft-Hartley formulation of those purposes."174

The results may be underinclusive in some respects. I only include cases in which the Board, acting as a three or five-member entity, itself actually engaged in statutory interpretation. ${ }^{175}$

171. See Semet, supra note 161. In the prior analysis, I only looked at unfair labor practice cases. $I d$.

172. These words include "statutory construction," "statutory interpretation," "plain meaning," "dictionary," "statutory canons," "redundancy," "exclusion," "clear statement," "canons of construction," searches for the Latin canons, and the names of other substantive and textual cases as well as searches for "ambiguous," or "text" within the same sentence as "statute" or "statutory." I also did searches under "concerted action" and various iterations of the word "violations" or "violate," and "statute." I separately did a search in the federal courts of appeals to see cases where courts applied Chevron or other deference regimes to see if I could pick up additional cases. As part of another project, I coded over 1400 appellate court decisions referencing the NLRB from 1993 through early 2017, and I referred to that dataset as an additional check. See Amy Semet, Predicting Deference in NLRB Appellate Court Cases (Working Paper 2019) (on file with author).

173. Fisk \& Malamud, supra note 20, at 2039.

174. Id. at 2039-40.

175. I exclude cases where the majority applied well-settled precedent but 
There are several cases in which the Board merely blesses the opinion of the ALJ by issuing a short order upholding the opinion. ${ }^{176}$ The ALJ may have set forth a statutory interpretation, but because there is no Board opinion, it is impossible to know whether the Board simply affirms the ALJ because it agrees with the result or because it in fact favors the statutory methodologies employed by the ALJ. ${ }^{177}$ Indeed, in some cases, the Board even notes in a footnote that while it upholds the decision, it does not necessarily agree with the ALJ's approach. 178

I also do not include cases in which the Board "implicitly" interprets the statute unless it is clear that the Board is setting forth a new rule to apply to future adjudications. For instance, the Board has a well-developed precedent to guide the determination of whether an employee was unlawfully terminated-the so-called Wright Line ${ }^{179}$ analysis whereby the Board analyzes a three-factor test of employer conduct and motivation to discern whether the conduct was unlawful. The Board hears hundreds of Wright Line cases where the Board applies precedent to determine whether a violation occurred. ${ }^{180}$ Similarly, in hundreds of cases, the Board reviews whether or not someone is an "employee" under the Act's provisions. ${ }^{181}$ In the dataset, I would have included a case like Wright Line, in which the Board devises a test as a matter of first impression, but I do not include the hundreds of cases applying the Wright Line test to various facts to discern whether someone is an "employee." In those cases, there is no dispute concerning the applicable law; rather, the inquiry is whether there is sufficient evidence to sustain a

the dissent advocated an overturning of that precedent. See, e.g., Bristol Farms \& Konny Renteria, 363 N.L.R.B. No. 45, at *3 (Nov. 25, 2015) (dissent disagreeing with Board precedent). I also did not double count cases issued the same day where the Board made identical statutory interpretation issues. See, e.g., Yukon Kuskokwim Health Corp., 329 N.L.R.B. No. 86 (Oct. 29, 1999) (making a similar statutory interpretation as another case issued the same day discussing jurisdiction under NLRA).

176. See, e.g., Lee Lumber \& Bldg. Material Corp., 322 N.L.R.B. 175 (1996) (blessing ALJ opinion in short summary opinion).

177. See, e.g., Mail Contractors of Am., Inc., 514 F.3d 27, 35 (D.C. Cir. 2008) (statutory interpretation done by ALJ).

178. See, e.g., Law-Den Nursing Home, Inc., 361 N.L.R.B. 119 (2014).

179. Wright Line, 251 N.L.R.B. 1083 (1980).

180. See, e.g., Atlanta Motor Lines, 308 N.L.R.B. 909 (1992).

181. Columbia Univ., 364 N.L.R.B. No. 90, at*1 (Aug. 23, 2016); N.Y. Univ., 332 N.L.R.B. 1205, 1209 (2006); Brown Univ., 342 N.L.R.B. 483, 490 (2004). 
violation. I also do not include cases in which the NLRB interprets a statute other than the NLRA, ${ }^{182}$ or in which the Board rules on internal administrative matters, which often arise in cases concerning union elections. ${ }^{183}$ Further, I do not include cases in which the statutory issue is fact-specific; for example, the Board may rule on whether conduct is "concerted activity." 184 Such an inquiry, however, is necessarily bound up in the specific fact situation of any one case, making it impossible to come up with a general rule to apply in future cases.

Some cases lack a clear interpretive strategy. The Board sets forth a fact scenario and makes a determination but does not specify its reasoning except to rely on caselaw. To the extent that these "caselaw only" decisions represent implicit policy determinations, the dataset would necessarily underestimate the extent to which the Board uses pure policymaking to guide statutory interpretations. However, there are several reasons for excluding such cases. None of these cases involve any discussion of the text of the NLRA, or its legislative history, or policy, or practical considerations, and the Board is not announcing that it is devising a new rule. Moreover, unlike the vast majority of the cases included in the dataset, hardly any of these cases have a dissent or concurrence. Given the frequency of Board dissents, this lack of dissenting opinions is likely an indication that the excluded cases involve easy to analyze factual situations clearly fitting within established precedent. Finally, these cases are decided by three-judge panels. Although not a strict rule (there are three-judge panel decisions included in the dataset), precedential cases are decided by the full Board. In any event, to the extent this study is underinclusive, it may exclude some cases where the NLRB's sole interpretive method is to piece together some sort of statutory interpretation from its own or Supreme

182. See, e.g., Teamsters Local Union No. 741, 321 N.L.R.B. 886 (1996) (interpreting the Equal Access to Justice Act); see also Times Herald Printing Co., 315 N.L.R.B. 700 (1994) (interpreting the Worker Adjustment and Retraining Notification Act of 1988).

183. For instance, in Firstline Transp. Sec., Inc., the Board defers to another administrative agency in how to interpret the Aviation and Transportation Security Act. 347 N.L.R.B. 447 (2006). I also do not include cases where the Board rules on its own procedures or processes or interprets its own regulations regarding the conduct of internal adjudicative matters. For instance, I do not include cases where the Board interprets the format of briefs or how a subpoena should issue, among other issues. See, e.g., Best W. City View Motor Inn, 327 N.L.R.B. 468 (1999).

184. See, e.g., Aroostook Cty. Reg'l Ophthalmology Ctr., 317 N.L.R.B. 218 (1995). 
Court caselaw laced together with a policy prescription. ${ }^{185}$ As an additional robustness check, in the course of reviewing both Board and appellate court decisions reviewing NLRB cases, ${ }^{186}$ I became familiar with all NLRB cases that were cited as precedent in other NLRB or appellate court decisions. Although the data is censored (meaning recent Board decisions made in 2015 or 2016 may not yet appear as precedent), I included any precedent-only cases cited repeatedly for new points of law or application of precedent to establish a new rule in a different factual situation. 187

The analysis rests on the assumption that the Board is transparent and that the opinions actually reflect the statutory methodology used by the Board. But as the Gluck and Posner survey found, what judges write in their opinions is not necessarily correlative with the statutory methods judges actually use

185. The Board occasionally cites circuit court cases, but its use is usually supplementary to Board or Supreme Court decisions. This is not all together surprising given that the Board engages in a policy of nonacquiescence of appellate court decisions. See, e.g., Estreicher \& Revesz, supra note 152, at 681. My data reveals that this policy is not merely theoretical; my own observation after reading over 7000 NLRB cases is that the Board rarely will voice concern that its ruling will conflict with a precedent set by whatever regional court will likely review the case. That said, I include some cases remanded from the court of appeals. Sometimes, the court of appeals remands for the Board to either (1) adopt the statutory interpretation of the court of appeals; or (2) to make clear what the Board's statutory interpretation actually was. I do not, however, double count cases. In the few situations where the Board hears a case multiple times, I include the case in which the Board interprets the statute and in one instance, I included the same case before and after remand since the interpretations differ. See, e.g., Randell Warehouse of A.Z., Inc., 347 N.L.R.B. 591 (2006); Randell Warehouse of A.Z., Inc., 328 N.L.R.B. 1034 (1999). I exclude cases in which the Board simply adopts the "law of the case" from the appellate court. See, e.g., Goodless Elec. Co., Inc., 332 N.L.R.B. 1035, 1037 (2000).

186. In another paper, I analyze and compare the statutory methods used by the appellate courts versus the Board. See Amy Semet, Empirically Examining Chevron Deference and NLRB Statutory Interpretation in the Appellate Courts (Working Paper 2019) (on file with author). I trace the cases cited in this dataset to see which methods the appellate court uses. $I d$. I also add additional cases where the appellate court invokes Chevron or otherwise engages in statutory interpretation. Id.

187. A small number of cases had more than one statutory interpretation. However, in all cases one interpretation was best resolved as a matter of first impression by another case so only that case was included. See, e.g., AnheuserBusch, Inc., 351 N.L.R.B. 644, 646 (2007) (NLRB case after remand used to analyze statutory interpretation on second issue on remedy); Anheuser-Busch, Inc., 342 N.L.R.B. 560 (2004) (statutory interpretation issue on unfair labor practice claim best resolved by Colgate-Palmolive Co., 323 N.L.R.B. 515, 515516 (1997)). 
to decide cases. 188 To some extent, use of a particular statutory method in a decision could be merely window-dressing. ${ }^{189}$ There is no way to know whether the opinion accurately or completely reflects the Board's interpretive process. The same concern, however, can be said of any empirical analysis of statutory interpretation, or analysis of judicial voting generally. 190 Selection effects could also be at work; only a small number of ALJ cases are appealed to the NLRB. ${ }^{191}$ Recognizing these limitations, the purpose of the study is not to draw predictive inferences but to show, in a descriptive fashion, how an agency interprets its governing statute.

Having set forth the limitations of this study, I next analyze the different interpretive methodologies employed by the Board. In preparing the dataset, I coded for the following statutory tools: the plain meaning rule; the Latin/language canons; substantive canons; legislative history (as well as source of legislative history); use of precedent; mentions of policy; and references to practical implications. These interpretive tools are similar to those studied in other empirical studies of statutory interpretation. 192

In coding policy, I look to statements about how the Board balanced competing policy needs or whether a given statutory interpretation would effectuate the stated goal of the NLRA to reduce inequality in bargaining or to inhibit strikes. Some cases could be coded as either precedent or policy. Cases are coded as policy if the Board adopts a new rule, even if that rule might simply be a return to a prior Board precedent since that involves a policy choice to abandon existing precedent. Practical consequences concern such things as the workability of the proposed ruling, the effect such a ruling would have on labor relations, the burdens imposed on the worker or the employer under the proposed ruling, or the overall effects that may occur in labor law

188. Gluck \& Posner, supra note 91 , at 1330.

189. Id.

190. Id. at 1315 ("We can acknowledge that judges use a mixture of interpretive tools and ... many judges do not seem to have a consistent or identifiable interpretative approach.”).

191. See generally George L. Priest \& Benjamin Klein, The Selection of Disputes for Litigation, 13 J. LEGAL STUD. 1 (1984) (describing the influences of private decisions that lead to or prevent cases from being litigated).

192. See, e.g., CROss, supra note 3, at 148 (analyzing the Roberts' Court use of statutory interpretive tools); Krishnakumar, supra note 10, at 922 (listing the interpretive tools within the empirical study). 
generally should the Board's rule stand. ${ }^{193}$ As in other empirical studies, I include the absurdity canon under policy or practical consequences. 194

I code an interpretive canon if the Board relies on it; if the opinion only mentions a canon in passing or if it rejects a particular tool as unpersuasive, I code for it separately, signifying that it was in response to a majority or dissenting opinion. ${ }^{195}$ Likewise, if the decision rank-ordered interpretive tools, I make note of it. In my analysis, I also code for the use of "dueling" canons by which the majority and dissent both employ the same interpretive canon to advance their viewpoint. ${ }^{196}$ Board members may "duel" with each other in a textual matter by (1) focusing on different words or seeing different relationships between parts of the statute; (2) differing in how narrow or broad they interpret the very same words; or (3) focusing on the same word but ascribing a different meaning to the text. ${ }^{197}$ Purposivists can also "duel" with each other by (1) focusing on different, competing purposes; (2) focusing on the same purpose but drawing different conclusions about that purpose; or (3) focusing on a broad, general statutory purpose while another decision maker focuses on narrowly drawn specific purposes. ${ }^{198}$

If a case has multiple dissents, I combine the dissents into one for purposes of this analysis so there are no mixed partisan dissents. That is, there are only a handful of cases in which both a Democrat and Republican Board member both dissent on a statutory interpretation issue. 199

193. See, e.g., Krishnakumar, supra note 10, at 922 (coding "practical consequences" as an interpretive tool).

194. Id.

195. See Bruhl, Statutory Interpretation, supra note 83, at 32.

196. Krishnakumar, supra note 10, at 912 (counting "dueling" as "those instances in which a majority and dissenting opinion in a case invoke the same interpretive tool to reach different readings of the statute").

197. Id. at 961 .

198. Id. at 971.

199. Most dissent writers employ the same methodology as their fellow dissent writer; in only four or five cases did one dissent use a statutory methodology that was not employed by the other dissents. Often, this methodology was legislative history, with one dissent writer employing legislative history to buttress their point. Moreover, about $71 \%$ of cases in the dataset concern a single dissent. Recent Board members Philip Miscimarra and Harry Johnson have a habit of writing very long and detailed separate dissents, a pattern that contrasts with the single dissents written during the Bush II and Clinton years. During the earlier period, Peter Hurtgen/J. Robert Brame and Wilma Liebman/Dennis Walsh often wrote joint dissents. 


\section{OVERVIEW OF RESUlTS OF STATUTORY INTERPRETATION AT THE NLRB IN MAJORITY OPINIONS}

The Board engaged in a mix of interpretative techniques in the twenty-four year period under study. In Section II.C.1, I detail the general trends, pointing out differences in interpretive methodology based on case type, partisan composition of the panel, and presidential administration. I then turn to a detailed empirical and doctrinal discussion of the Board's use of each interpretive method. In Section II.C.2, I discuss the use of textualism by the Board, detailing how the Board uses textual, Latin/language, and substantive canons of interpretation before reviewing the Board's use of legislative history in Section II.C.3. Section II.C.4 discusses the use of precedent, and Section II.C.5 describes the Board's use of policy and practical considerations in its decision making. Finally, Section II.C.6, summarizes the findings.

\section{General Trends in Statutory Interpretation of Majority Opinions}

Table 1 lists descriptive statistics of the 168 cases in the dataset that interpreted the NLRA in majority opinions as a matter of first impression. Not surprisingly, the full four or five member Board heard $58 \%$ of the cases in the dataset. Each case employs multiple tools. For instance, a Board decision could employ text, Latin/language canons, substantive canons, legislative history, precedent, policy, and practical considerations all in one decision, underscoring empirical support that the eclecticism Gluck and Posner found for appellate court judges similarly applies to administrative agencies. ${ }^{200}$ Figure 1 details the percent value for each methodology, by case type. "Text" refers to cases in which the Board analyzes the text in part, but the use of text is equal to or secondary to other interpretive methods. "Plain text" references cases in which the Board primarily rests its conclusions on the text by arguing that the text has a plain meaning that controls the outcome of the case. ${ }^{201}$

200. Gluck \& Posner, supra note 91, at 1303.

201. Some scholars do not conduct significance tests because their dataset, like the present one, consists of the entire population of cases under study. See Eskridge \& Baer, supra note 60, at 1095-96 (explaining the reason for not running significance tests). In statistics, one can assess whether a difference in two sample means is statistically significant by conducting various statistical tests, such as t-tests. The present study, like the others, consists of the full population 
Table 1: Methods of Statutory Interpretation: Majority Opinions (Percents)

\begin{tabular}{|c|c|c|c|c|c|c|c|c|c|}
\hline & All & Text & Plain & Lang. & Subs. & L.H. & Prec. & Policy & Prac. \\
\hline All Cases & & 61.3 & 6.0 & 36.3 & 14.3 & 30.4 & 98.8 & 83.9 & 57.1 \\
\hline \multicolumn{10}{|l|}{ Case Type } \\
\hline Employer & 55.7 & 58.1 & 6.5 & $28.0^{*}$ & 11.8 & 24.7 & 97.9 & 83.9 & $58.1^{*}$ \\
\hline Union & 15.0 & 80.0 & 8.0 & $56.0^{*}$ & 24.0 & 48.0 & 100.0 & 72.0 & $32.0 *$ \\
\hline Election & 29.3 & 59.1 & 4.1 & $44.9^{*}$ & 14.3 & 32.7 & 100.0 & 89.8 & $69.4^{*}$ \\
\hline \multicolumn{10}{|l|}{ Maj. Party } \\
\hline Republican & 32.1 & 66.7 & 11.1 & 33.3 & 14.8 & 37.0 & 100 & $70.4^{*}$ & 48.2 \\
\hline Democratic & 67.9 & 58.8 & 3.5 & 38.6 & 14.0 & 27.2 & 98.3 & $90.4^{*}$ & 61.4 \\
\hline \multicolumn{10}{|l|}{ Adm. } \\
\hline Clinton & 51.2 & $54.1^{*}$ & 5.8 & 31.8 & 9.4 & 25.9 & 98.8 & $78.8^{*}$ & $43.5^{*}$ \\
\hline Bush II & 28.9 & $64.6^{*}$ & 8.3 & 35.4 & 16.7 & 27.1 & 100.0 & $83.3^{*}$ & $62.5^{*}$ \\
\hline Obama & 19.9 & $78.8^{*}$ & 3.0 & 54.6 & 24.2 & 45.6 & 97.0 & $100.0 *$ & $87.9^{*}$ \\
\hline \multicolumn{10}{|l|}{ Party/Adm. } \\
\hline Rep./Clinton & 13.7 & 65.2 & 13.0 & 39.1 & 13.0 & 39.1 & 100.0 & $56.5^{*}$ & $21.7 *$ \\
\hline Dem./Clinton & 36.9 & $50.0^{*}$ & 3.2 & $29.0^{*}$ & 8.1 & $21.0^{*}$ & 98.4 & 87.1 & $51.6^{*}$ \\
\hline Rep./Bush & 17.9 & 70.0 & 10.0 & 30.0 & 16.7 & 33.3 & 100.0 & $83.3^{*}$ & $70.0^{*}$ \\
\hline Dem./Bush & 10.7 & $55.6^{*}$ & 5.6 & $44.4^{*}$ & 12.5 & $16.7^{*}$ & 100.0 & 83.3 & $50.0^{*}$ \\
\hline Rep./Obama & 0.0 & 0.0 & 0.0 & 0.0 & 0.0 & 0.0 & 0.0 & 0.0 & 0.0 \\
\hline Dem./Obama & 19.6 & $78.8^{*}$ & 3.0 & $54.6^{*}$ & 24.2 & $45.6^{*}$ & 97.0 & 100.0 & $87.9^{*}$ \\
\hline
\end{tabular}

${ }^{*}$ Statistically significant at least $95 \%$ confidence. There were no applicable Republican-majority panels during the Obama administration.

of cases, not simply a randomly drawn sample. Nonetheless, I conduct hypothesis testing by using chi-squared analysis to determine whether the means of select groups differ from one another. 
Figure 1

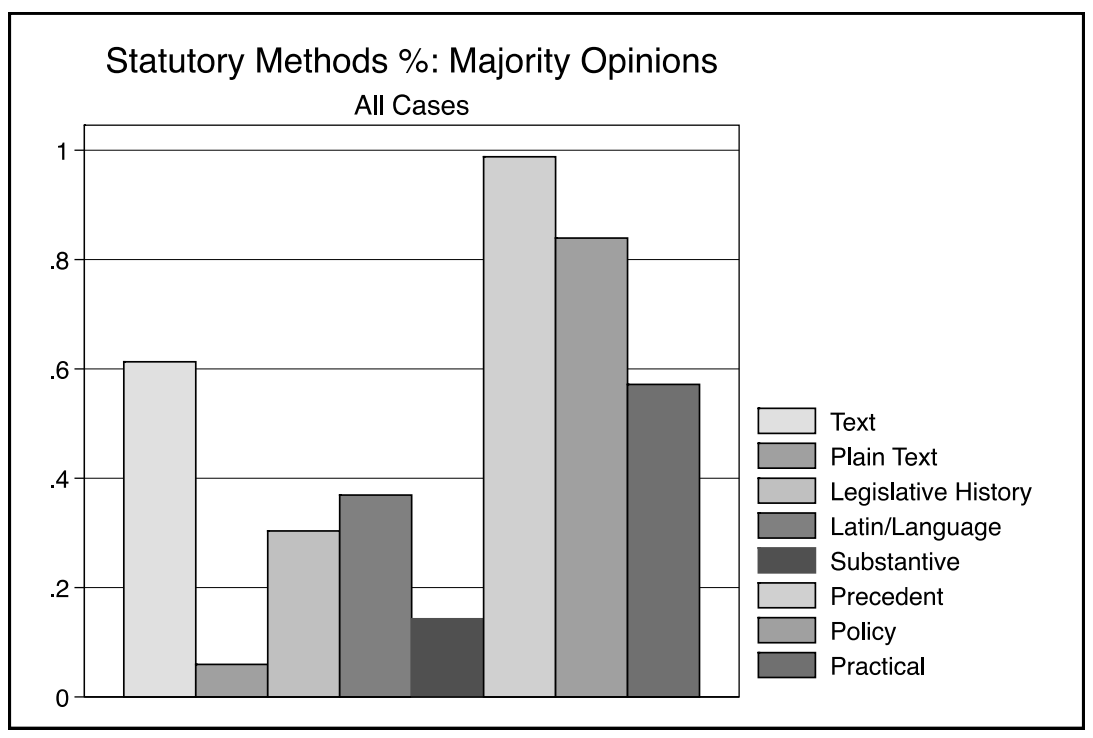

Board members cite to the text or engage in some type of textual analysis $61 \%$ of the time. However, the Board finds the text to be controlling (or references the text being "plain") in less than $10 \%$ of cases (6\%). Even in those cases, the Board does not rely solely on the text. In $70 \%$ of those cases, the Board buttresses its textual argument by relying on legislative history at least in part and they always refer to precedent. Moreover, in $80 \%$ of cases in which the Board finds the text plain, the Board complements its textual analysis by referring to policy considerations and in $40 \%$ of these cases, the Board also references the practical implications of its rulings. Plain meaning is used slightly more often in cases against unions, but the differences are not statistically significant. The Board seems to engage in at least some textualist interpretation about two-thirds of the time, with text used more in cases against unions, though the differences are not statistically significant. The Board uses Latin/language canons in about a third of their cases and uses substantive canons about $14 \%$ of the time. It employs Latin/language canons in over half of the cases against unions and in $45 \%$ of election or bargaining unit cases, with the differences being statistically significant. This result is not surprising because in cases against unions or cases involving election or bargaining units, the Board must determine who qualifies as an "employee" under the Act, 
an inquiry that seems particularly well-suited to textual analysis and invocation of language canons. ${ }^{202}$

The Board uses purposive methods, at least in part, in almost all of the decisions in the dataset. In $30 \%$ of statutory interpretation cases, the Board majority refers in part to legislative history or congressional intent, even if only second-hand or in a general way; legislative history is extensively discussed in $18 \%$ of cases. The Board most frequently cites to legislative history in cases containing allegations of union abuses (48\%).

In addition, the Board also frequently references precedent, citing caselaw to support the outcome in $99 \%$ of cases in the dataset. Most frequently, the Board references other Board decisions in nearly all its decisions, citing them extensively in support of the statutory interpretation $44 \%$ of the time. Either circuit court or Supreme Court precedent, however, influence a majority of interpretations at least in part and in $6 \%$ of cases, the Board closely mirrors the statutory construction given by an appeals court; it is highly influential in 14\%.203 Given the Board's stated policy of nonacqueiscence, ${ }^{204}$ this finding is surprising. Moreover, the Board cites at least one Supreme Court decision as influencing its construction in $80 \%$ of the cases; it finds the Supreme Court decision constraining or definitive in $16 \%$ of cases in the dataset.

In addition to legislative history and precedent, the Board frequently cites policy and practical considerations. In $84 \%$ of cases, the Board voices policy implications explicitly or implicitly. In some instances, the Board makes clear that the statute leaves the agency a hole to fill and the Board must balance competing considerations. ${ }^{205}$ In other cases, the Board makes a policy choice between competing Board precedents. Given that the Board is, at its heart, a policymaking body, it is no surprise that policy considerations often animate choice where Congress leaves a discernible "gap" in the law. Practical considerations also play some role in decision making in $57 \%$ of cases, especially in election representation and bargaining unit cases (69\%), a dif-

202. See infra Part II.C.2.b.

203. See, e.g., Stauton Fuel \& Material, Inc., 335 N.L.R.B. 59, 59 (2001) (applying Tenth Circuit case law).

204. Estreicher \& Revesz, supra note 152, at 681 (discussing the practice of agency nonacquiescence in American law).

205. See, e.g., Morgan's Holiday Mkts., Inc., 333 N.L.R.B. 837, 840-41 (2001) (balancing considerations). 
ference that is statistically significant. As detailed more fully below, these cases often concern broader issues than unfair labor practice cases do. For example, many of these cases concern identifying individuals qualifying for protection under the NLRA, ${ }^{206}$ a conclusion that has far-reaching implications about the scope of the Board's jurisdiction in labor policymaking. As such, it is not surprising that in those cases in particular, the Board often gives consideration to practical implications.

Figure 2

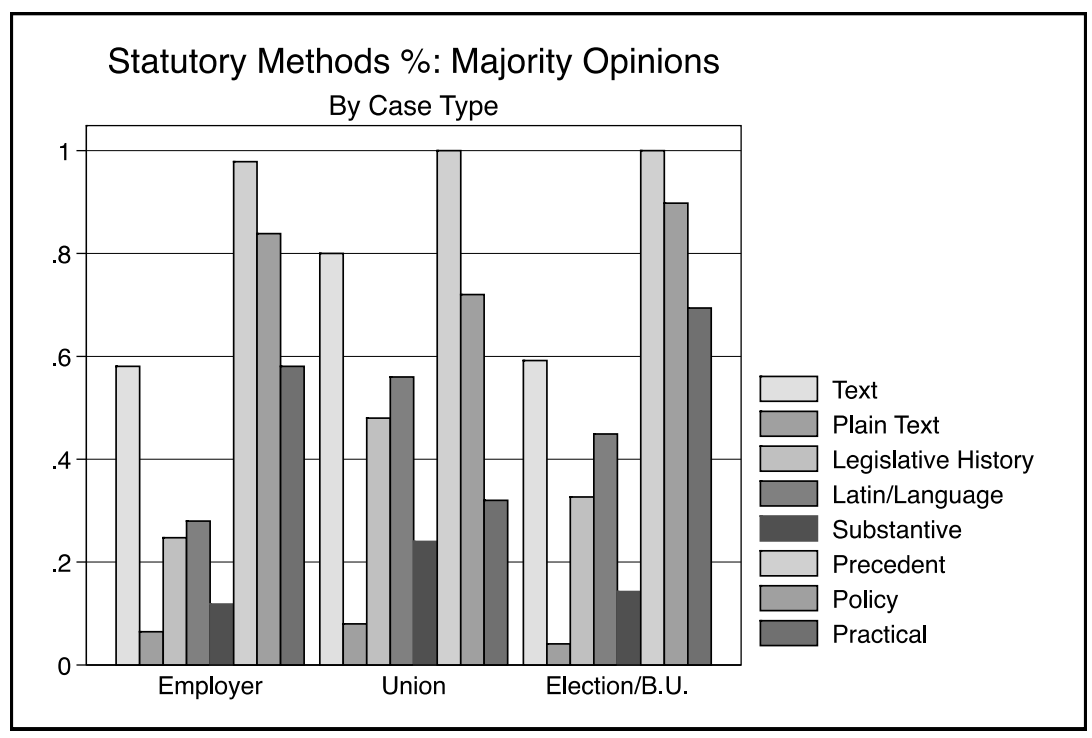

Table 1 and Figure 3 also looks at the methodologies broken down by the majority party of the panel hearing the case. ${ }^{207}$ During the period under study, $68 \%$ of the panels have Democraticmajorities, with a handful of cases being handled by split majorities. ${ }^{208}$ While Republican-dominated panels use text, plain meaning, and legislative history more than Democratic-domi-

206. See, e.g., Columbia Univ., 364 N.L.R.B. No. 90 (Aug. 23, 2016) (adjudicating if an individual student assistant is a statutory employee).

207. There was only one Republican panel that heard relevant cases during the Obama administration so that case was eliminated for purpose of the tables.

208. In the few cases where the party of the majority was split, for ease of analysis, I coded the party as Democratic-dominated if the decision was in favor of unions and Republican if the decision was in favor of the employer. 
nated panels, the differences are not statistically significant. Indeed, most striking is the fact that there are so few differences based solely on majority party. Moreover, Democratic-majority panels tend to use Latin/language canons (39\% v. 33\%), policy (90\% v. 70\%), and practical implications (61\% v. 48\%) more than Republican panels, though only policy is statistically significant and it is largely limited to cases undertaken during the Clinton administration. Both parties equally employ precedent and substantive canons.

Figure 3

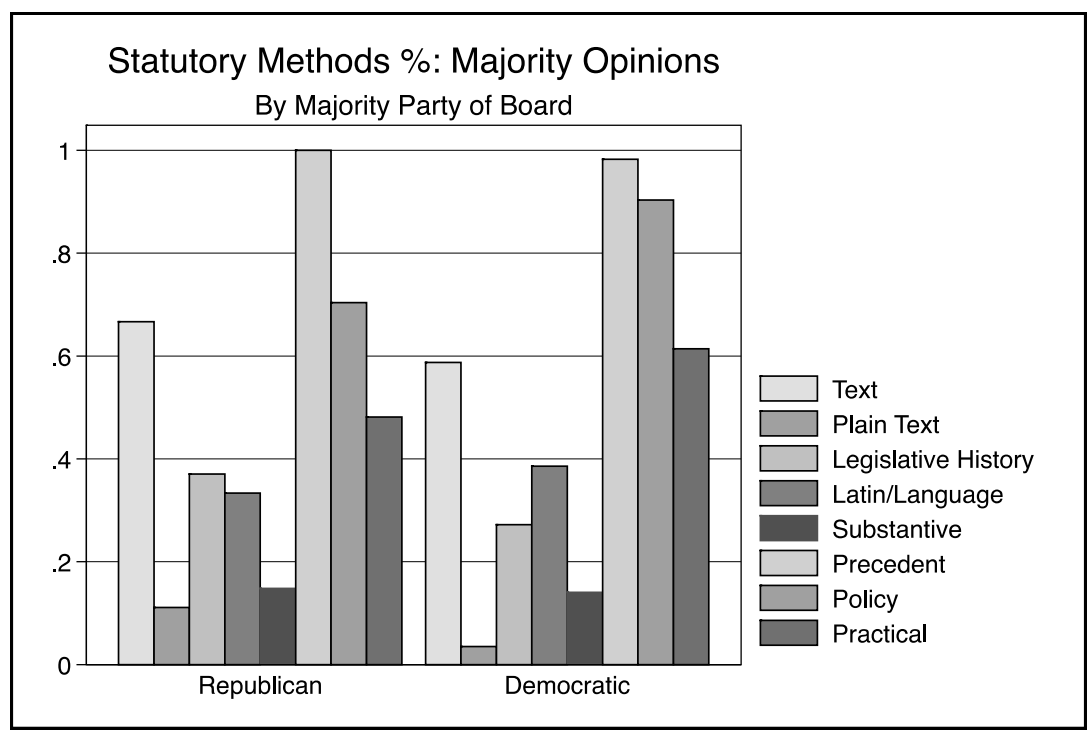

Figure 4 breaks down the data by presidential administration. There is a statistically significant jump in the use of text starting in the Bush II administration as well as an increase over time in the use of the text, the Latin/language canons, the substantive canons, legislative history, policy, and practical considerations with the increase in text, policy, and practical considerations being statistically significant. Table 1 also looks at the data broken down by both party and presidential administration. Of note is the fact that Democratic-majority panels have become more textualist over time, with increased reliance on text and the Latin/language and substantive canons especially during the Obama administration. This is an interesting finding considering the popular wisdom associating Democrats with a 
more purposive approach. ${ }^{209}$ Use of legislative history also increased during the Obama administration.

Figure 4

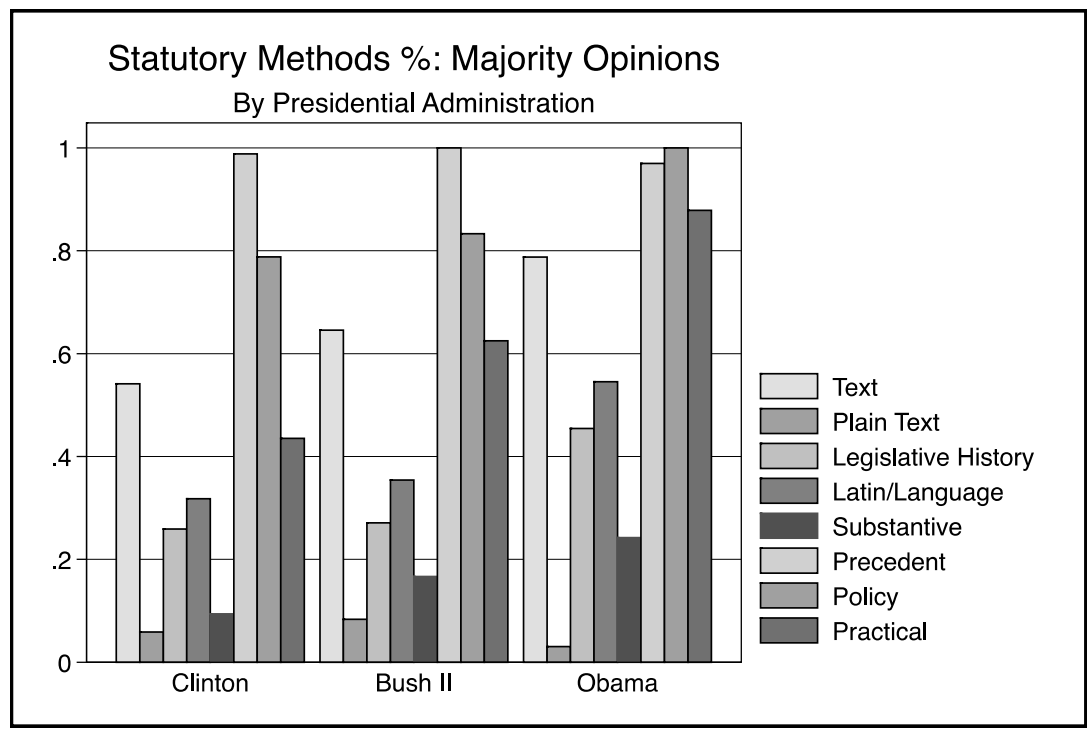

Table 2 and Figure 5 detail the single primary method of interpretation in a given case. I assign each case to one of five groups: (1) text plus (cases which rely primarily on the text and/or text plus legislative history, often accompanied by discussion of policy and practical implications); (2) plain text (where Board finds the text alone to be dispositive of the proper interpretation even if the Board buttresses its conclusion through other sources); (3) legislative history primary (cases in which the Board uses legislative history as the primary method to fill a gap in the law to construe a statute); (4) precedent primary cases (cases in which the Board uses some combination of Board, circuit court, or Supreme Court precedent as constraining its statutory construction); and (5) policy/balance cases (cases in which the Board acknowledges that there is a gap in the law and the

209. Miles \& Sunstein, supra note 60, at 828-29 ("[T] necessary connection between adoption of 'plain meaning' approaches and being 'liberal' or 'conservative.' But as an empirical matter, the more conservative Justices ... have embraced 'plain meaning' approaches and the more liberal justices have not."). 
Board makes a policy-based decision either by balancing competing priorities or by considering various policy rationales and/or practical consequences to inform statutory meaning or by making a policy choice by overruling an older Board precedent or choosing between Board precedents to create a new rule).

Table 2: Primary Method of Statutory Interpretation: Majority Opinions (Percents)

\begin{tabular}{lccccc} 
& Text+ & Plain & L.H. & Prec. & Policy \\
\hline All Cases & 19.6 & 3.0 & 2.4 & 35.7 & 39.3 \\
\hline Case Type & & & & & \\
Employer & 12.9 & 2.2 & $1.1^{*}$ & $43.0^{*}$ & $40.9^{*}$ \\
Union & 32.0 & 4.0 & $12.0^{*}$ & $36.0^{*}$ & $16.0^{*}$ \\
Election & 26.5 & 4.1 & $0.0^{*}$ & $20.4^{*}$ & $49.0^{*}$ \\
\hline Maj. Party & & & & & \\
Republican & 24.1 & 5.6 & 5.6 & 35.2 & 29.6 \\
Democratic & 17.5 & 1.8 & 1.0 & 36.0 & 43.9 \\
\hline Adm. & & & & & \\
Clinton & $9.4^{*}$ & 2.4 & 4.7 & $47.1^{*}$ & 36.5 \\
Bush II & $25.0^{*}$ & 6.3 & 0.0 & $29.2^{*}$ & 39.6 \\
Obama & $36.4^{*}$ & 0.0 & 0.0 & $15.2^{*}$ & 48.5 \\
\hline Party/Adm. & & & & & \\
Rep./Clinton & 13.0 & 4.4 & $13.0^{*}$ & $52.2^{*}$ & 17.4 \\
Dem./Clinton & $8.1^{*}$ & 1.6 & 1.6 & $45.2^{*}$ & 43.6 \\
Rep./Bush & 30.0 & 6.7 & $0.0^{*}$ & $23.3^{*}$ & 40.0 \\
Dem./Bush & $16.7^{*}$ & 5.6 & 0.0 & $38.9^{*}$ & 38.9 \\
Rep./Obama & 0.0 & 0.0 & 0.0 & 0.0 & 0.0 \\
Dem./Obama & $36.4^{*}$ & 0.0 & 0.0 & $15.2^{*}$ & 48.5 \\
\hline Statistically significant at & $95 \%$ & & & & \\
\hline
\end{tabular}

${ }^{*}$ Statistically significant at least $95 \%$ confidence. There were no applicable Republican-majority panels during the Obama administration.

In all, as detailed in Table 2 and Figure 5, reliance on policy $(39 \%)$ and precedent $(36 \%)$ are the most common primary tool for interpretation, with both groups together comprising nearly three-fourths of the cases. In 29\% of cases, the Board makes apparent that its statutory interpretation is highly influenced by Supreme Court precedent. ${ }^{210}$ Likewise, $44 \%$ of cases rely heavily on Board caselaw, while 14\% cite appellate court caselaw as being very important for the interpretation. In under a fifth of cases, the Board relies primarily on some sort of textual analysis, though the plain meaning is the primary method in only $3 \%$ of

210. See, e.g., The Raymond F. Kravits Ctr. for the Performing Arts, 351 N.L.R.B. 143, 147 (2007) ("[W]e have decided to abandon the Board's due process requirement for unions affiliation in light of the Supreme Court's decision in Seattle-First."). 
cases. The Board resorts to legislative history as the primary source for interpreting the statute in $2 \%$ of cases.

Figure 5

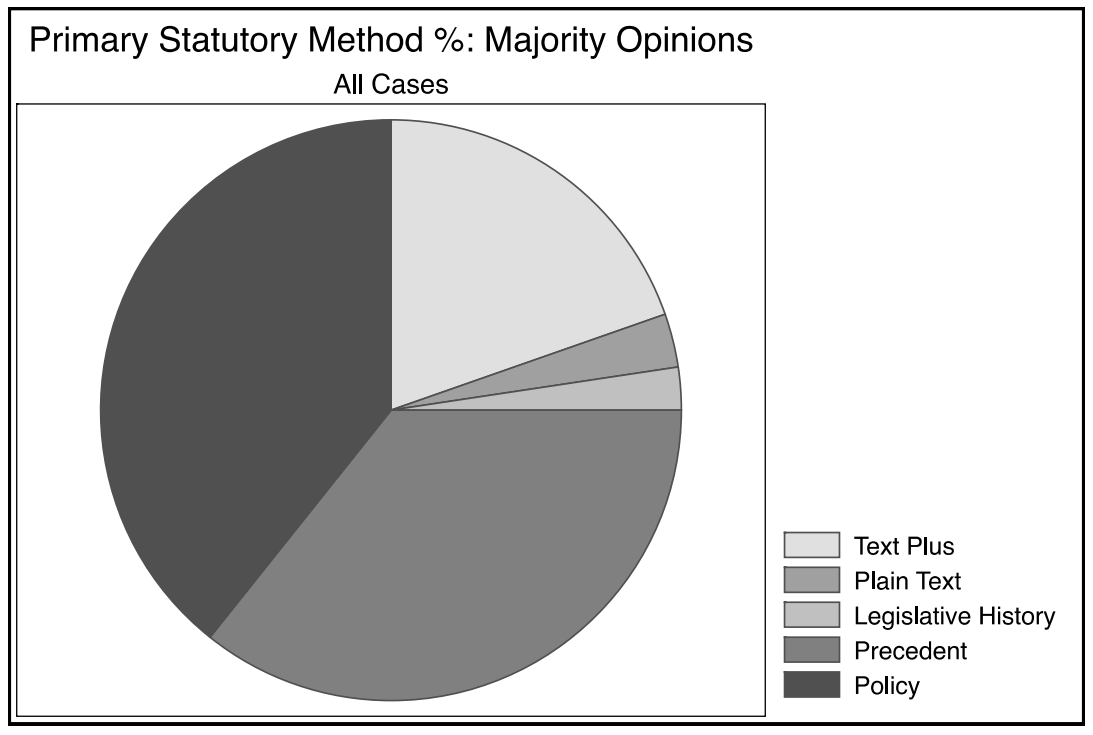

Figure 6 details the breakdown by case type, indicating that cases involving union abuses as well as election and bargaining units cases are more likely to use a text plus analysis. Claims against unions also are more likely to invoke legislative history as the primary source to a statistically significant degree. Further, use of precedent is more common in cases against employers to a statistically significant degree, while policy is rarely invoked as the primary method in cases against unions. 
Figure 6

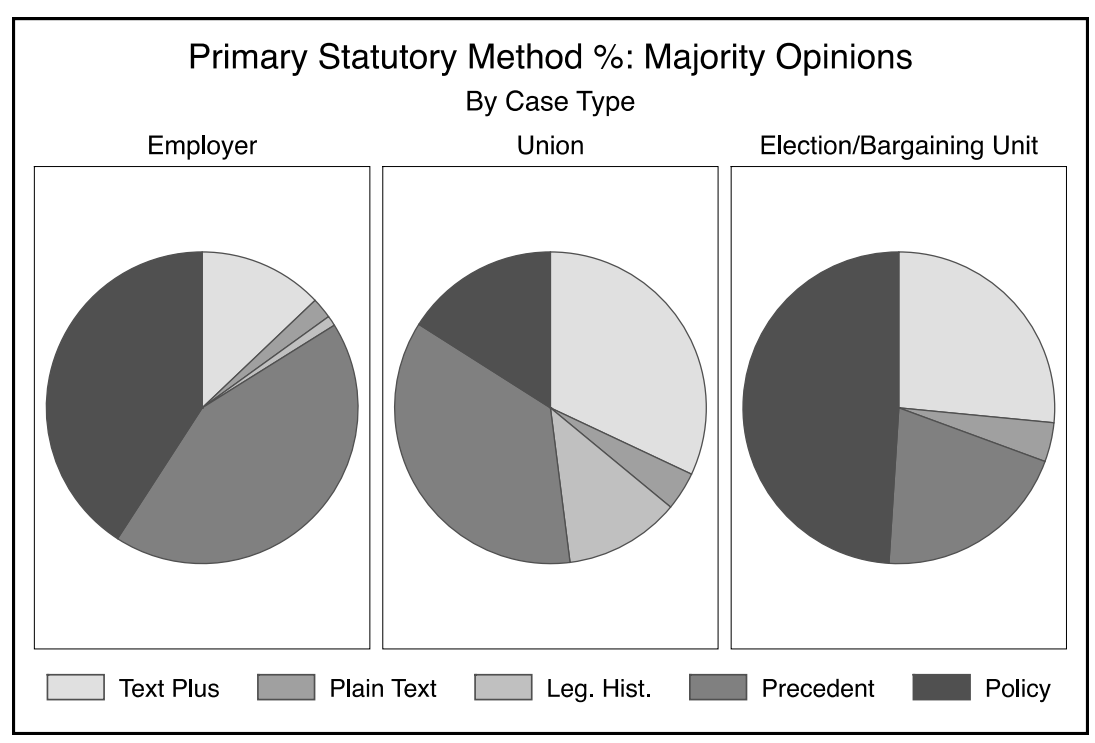

Figure 7 turns to breaking down the data by partisan composition of the panel, showing that the primary interpretive method employed is nearly identical between Republican and Democratic-majority panels. While Republican-dominated Boards are more likely to use text plus, plain text, and legislative history as the primary method than their Democratic counterparts, the results are not statistically significant. Democraticmajority panels are more likely to use policy as a primary source, but differences are not statistically significant (44\% v. 30\%). Further, since the text plus analysis often employs policy-based justifications in part, comparing Democratic and Republican-dominated Boards based on whether they employ either text plus or policy reveals that they are statistically indistinguishable since Republican Boards employ text plus slightly more than Democratic Boards. 
Figure 7

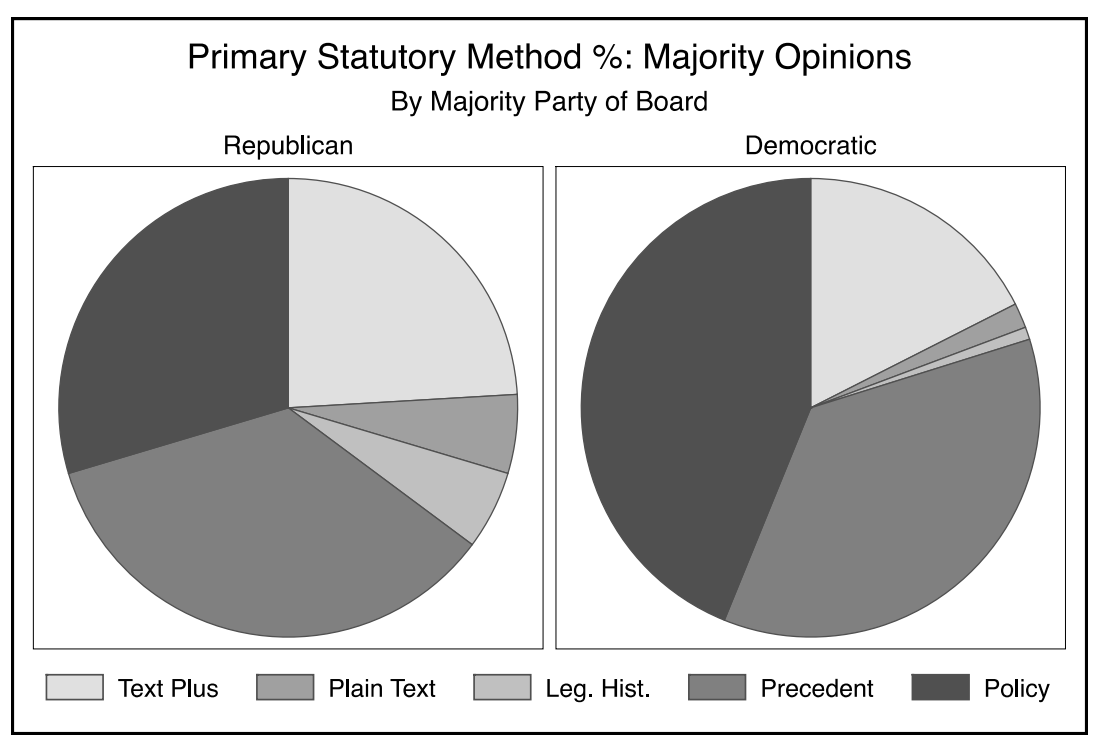

Table 2 and Figure 8 displays the primary method broken down by presidential administration. In particular, there is a marked increase in the text plus method over time. Whereas only 9\% of Clinton era Board decisions employ text plus analysis as the primary interpretive method, $36 \%$ of cases decisions during the Obama period use this method, a statistically significant increase. In turn, the Bush II Board used a plain text method in $6 \%$ of the cases, compared to $2 \%$ of cases during the Clinton years and none during the Obama years, a result that is statistically indistinguishable. There is also a noticeable decline in the use of precedent as the primary interpretive source in later administrations; whereas the Clinton Board decided almost half of its statutory decisions by cobbling together precedent as the key interpretive source, the Obama Board relied on this method in only $15 \%$ of its statutory cases of first impression-a statistically significant difference. Obama Board decisions also invoked policy considerations as the primary interpretive method $49 \%$ of the time compared to $36 \%$ during the Clinton era and $40 \%$ during the Bush II era. Statutory interpretation cases decided by the Obama Board seem to employ a predictable pattern: the three liberal Board members use primarily a text plus legislative history or policy-based approach to rule in favor of the liberal side, with Board members writing detailed dissents attacking the reasoning of the liberal majority with a text plus approach. 
Figure 8

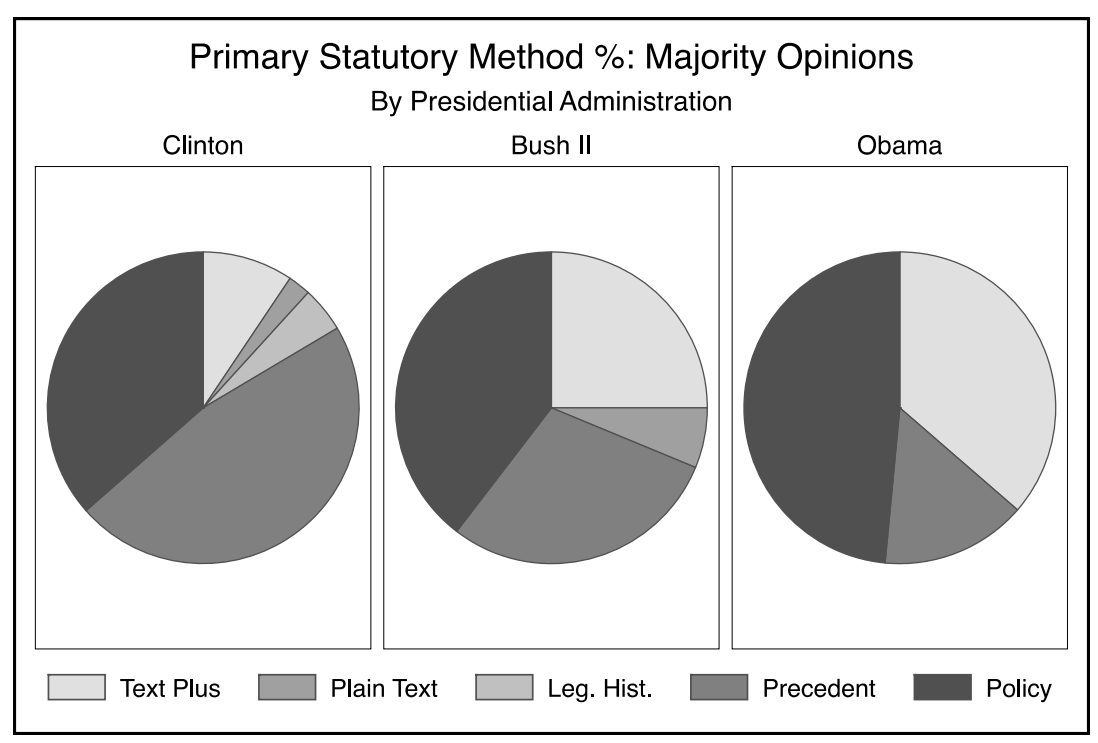

Table 2 also breaks down the primary method employed based on presidential administration and the majority party of the panel. Here again, there are noticeable differences based on the administration. The results underscore that the party in charge of the presidency is most likely to make its decisions with policy considerations at the forefront, and this trend has increased over time. Moreover, text plus analysis as the primary method of interpretation has increased over time, especially among Democratic-dominated panels. Democratic-majority panels in the Bush II and Obama administrations were especially likely to eschew legislative history in favor of a more policybased approach, while Republican-majority Boards during the Clinton administration often looked to legislative history as well as text to impose limits on labor rights. Decline in the use of precedent as a primary interpretive method is prevalent among both Republican and Democratic-majority panels to a statistically significant degree. As in other tables, Table 2 shows clearly the decline of the use of precedent and the increase in the use of both text plus and policy. Increase in the use of text plus and policy is especially prominent for Republican-dominated panels. 
2. NLRB's Use of Textualism, Latin/Language and Substantive Canons

The Board engages in different types of textual analysis. In this Section I set forth and explore each of the three typologies in turn: (1) plain meaning textualism; (2) "expansive" textualism; and (3) textualism by reliance on Latin/language canon.

\section{a. Plain Meaning Textualism}

In the "primarily textualist" cases cited above, the Board reads the text as mandating a certain interpretation by the clear import of the text. Plain meaning textualism has minimal influence on how the Board interprets statutes, as the Board adopts a plain meaning approach in less than $10 \%$ of the majority opinions studied. Even when the Board holds that the statutory text clearly necessitates a given result, the Board goes further to examine the legislative history, precedent, policy, or practical considerations of its ruling.

The Board adopted a plain meaning textualist approach in Alexandria Clinic, P.A. ${ }^{211}$ In that case, the Board reversed the ALJ's finding that the employer violated sections 8(a)(1) and 8(a)(3) of the NLRA by terminating striking nurses. ${ }^{212}$ The Board made clear that the text controls: "[s]ince the text of the statute is the law and that text is crystal clear and unambiguous, no further discussion is necessary." 213 In so ruling, the Board overruled its prior decision in Greater New Orleans, ${ }^{214}$ which had relied on legislative history to inform the meaning of the statute, giving strikers more flexibility in the notice requirements. ${ }^{215}$ The Board criticized the Greater New Orleans decision for using legislative history to "rewrite the statute" to make the notice requirement discretionary rather than mandatory. ${ }^{216}$ Even though the Board found the text to be clear warranting "no further discussion," the Board still went on to note that "policy considerations underlying Section 8(g) are effectuated" by applying it to the striking workers in the case. ${ }^{217}$

211. Alexandria Clinic, P.A., 339 N.L.R.B. 1262 (2003).

212. Id. at 1263 .

213. Id. at 1265 .

214. Greater New Orleans Artificial Kidney Ctr., 240 N.L.R.B. 432 (1979) (finding no violation under section $8(\mathrm{~g})$ ).

215. Alexandria Clinic, P.A., 339 N.L.R.B. at 1262.

216. Id. at 1265 .

217. $I d$. 


\section{b. Expansionist Textualism}

Instead of the plain language mandating a specific result, the Board often adopts a textualist approach to argue that the text does not forbid a certain interpretation or that the language of the text, when read together with surrounding language or the text of other sections, either necessitates a given result or offers one among many permissible interpretations of the statute. In $18 \%$ of the cases in which the Board refers at least in part to the text, the Board makes clear the text either does not limit an interpretation or does not foreclose an alternative interpretation.

The Board most frequently uses an expansionist textual method to rule on the breadth of coverage under the NLRA. The Board has earned criticism for its frequent flip-flopping on the NLRA's reach, especially with respect to interpreting who constitutes an "employee" under the Act. ${ }^{218}$ In recent years, the Board heard a flurry of cases concerning whether medical residents, interns, and graduate student teaching assistants (TAs) are considered "employees" for purposes of the NLRA. After amendments to the NLRA in the 1970s granting the Board jurisdiction over private hospitals, the Board held that residents and teaching assistants fell outside the Act's protection. ${ }^{219}$ By 1999, the Board, now controlled by Democrats, flip-flopped, overturning the NLRB rulings from the 1970s and extending protection to residents and TAs. ${ }^{220}$ Following another administration change, the Board once again overturned its decisions regarding TAs in 2004. ${ }^{221}$ Then, in 2016, the Board-again controlled by Democrats-overturned its 2004 ruling and found that graduate TAs in private universities were covered by the protections of the NLRA. ${ }^{222}$

The Board's decision in Columbia University shows how the Board expansively interprets the Act's words to bring additional

218. See Flynn, supra note 134, at 1363 (noting the partisan foundation of the NLRB).

219. See, e.g., St. Clare's Hosp. \& Health Ctr., 229 N.L.R.B. 1000, 1003-04 (1977) (holding that house staff are employees but cannot bargain); Cedar's-Sinai Med. Ctr., 223 N.L.R.B. 251, 251 (1976) (holding that house staff are not "employees" under the NLRA); Leland Stanford Junior Univ., 214 N.L.R.B. 621, 621 (1974) (holding that TAs are not employees); Cornell Univ., 183 N.L.R.B. 329, 331 (1971) (asserting jurisdiction over private, nonprofit universities).

220. N.Y. Univ., 332 N.L.R.B. 1205 (2000); Bos. Med. Ctr. Corp., 330 N.L.R.B. 152 (1999).

221. Brown Univ., 342 N.L.R.B. 483, 490 (2004).

222. Columbia Univ., 364 N.L.R.B. No. 90 (Aug. 23, 2016). 
people within the ambit of the NLRA. ${ }^{223}$ For at least the third time in a decade, the Board addressed whether TAs are "employees" as defined by section 2(3) of the Act. 224 The Board noted that the Act specifically states the Act covers "any employee," listing several exceptions such as independent contractors. ${ }^{225}$ Because the statute does not expressly list TAs as an exception, the Board reasoned, teaching assistants are within the Act's "any employee" coverage. ${ }^{226}$ Applying a modified version of expressio unius, the inclusion of a list of persons who are not employees suggests that a TA, not being identified, should be considered within the definition. ${ }^{227}$ The Board frequently uses this type of expansionist textualism in its decisions-often reciting that "nothing in the text limits" the Board's interpretation. Even when using this textualist approach, the Board refers to legislative history or policy as well to supplement its expansionist reading of the statute. ${ }^{228}$

\section{c. Latin/Language and Substantive Canons}

The Board also uses Latin/language and substantive canons to inform statutory meaning, though no case in the dataset mentions any of the Latin canons by name. ${ }^{229}$ Figure 9 details the Latin/language and substantive canons used by the Board. Majority opinions invoke language canons between $25 \%$ and $37 \%$ of the cases in the dataset, depending on how one defines language canons. Substantive canons are used $14 \%$ of the time. The Board most frequently invokes the whole text rule in over a third of its

223. Id. at *1; see also N.Y. Univ., 332 N.L.R.B. at 1209 (advancing a textualist approach to find TAs covered).

224. Columbia Univ., 364 N.L.R.B. at *1.

225. Id.

226. Id. at *1-2.

227. Id. at *4-6 ("The absence of student assistants from the Act's enumeration of categories excluded from the definition of employee is itself strong evidence of statutory coverage.").

228. When the Board advances an expansionist "no limits" reading of the statute, it only refers to practical implications $73 \%$ of the time.

229. Interestingly, the only time the Board invokes any of the Latin terms by name is in contract interpretation cases. In those cases, the Board notes that methods of statutory interpretation-such as expression unius-could also be used to interpret the language of the contract. See, e.g., Comput. Scis. Raytheon, 318 N.L.R.B. 966, 969 (1995). 
statutory interpretation cases, relying on other parts of the statute to interpret a specific statutory provision or term. ${ }^{230}$ For instance, in interpreting whether a union committed an unfair labor practice, the Board may refer to the provisions governing unfair labor practices against employers to inform meaning. ${ }^{231}$ The Board also frequently uses other nearby provisions to inform meaning of a given statutory term. In other instances, the Board refers to the "structure of the Act" as influencing its interpretation.

Figure 9

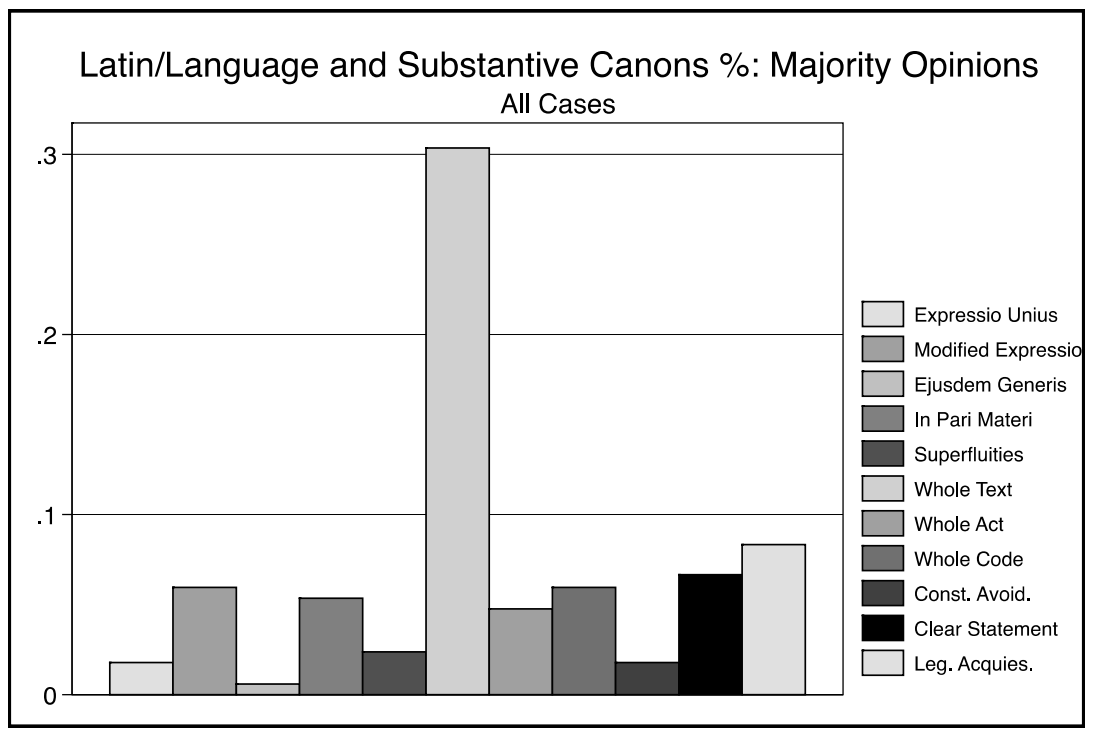

In addition to the whole text rule, the Board uses the whole act and whole code rule to inform statutory meaning in $5 \%$ and $6 \%$ of cases, respectively. The whole act rule is most often used when interpreting who is or is not an "employee" under the NLRA. ${ }^{232}$ The whole code rule is most frequently invoked in cases that require the Board to interpret the Railway Labor Act (RLA), which the Supreme Court has stated is "analogous" to the

230. See, e.g., Milwaukee \& Southeast Wis. Dist. Council of Carpenters, 318 N.L.R.B. 714, 716 (1995).

231. As an example, the Board frequently refers to section 8(a)(3) to interpret section 8(b)(1)(a) charges. See, e.g., Cal. Saw \& Knife Works, 320 N.L.R.B. 224, 224-225 (1995).

232. See, e.g., Columbia Univ., 364 N.L.R.B. at *1. 
NLRA. ${ }^{233}$ Much of the debate concerning the RLA centers on whether the two acts are statutory equivalents, so that Supreme Court precedents on the RLA can be used to inform statutory meaning of the NLRA. ${ }^{234}$ The Board also sometimes interprets the NLRA by looking at how other statutes such as Title VII or the Americans with Disabilities Act interpret a similar term. ${ }^{235}$

The Board rarely relies on any of the Latin/language canons exclusively and never mentions them by their formal name. For clarity, I specify that the Board here uses the expressio unius canon to include what was not expressly excluded; thus, I label it "modified expressio unius." Most of the cases in which the Board uses modified expressio unius involve determinations of whether a given "employee" comes within the ambit of the Act. ${ }^{236}$ It uses expressio unius in $2 \%$ of cases while it uses the modified version in 6\%. Further, in addition to the Latin/language canons, the Board also uses other rules of language or grammar to inform meaning. For instance, the Board notes that the statute's text should be read so as to avoid redundancy or to avoid superfluities, but employs this canon in fewer than $2 \%$ of cases. ${ }^{237}$

The Board also uses Latin and language canons to advance text-based arguments. For example, in Lincoln Lutheran of Racine, the Democratic-majority Board broadly interpreted section 8(a)(5) of the NLRA by referring to other parts of the statute, which it held "creates no obstacle to finding that an employer violates the Act by unilaterally discontinuing dues checkoff after contract expiration." 238 Other provisions of the statute contain

233. In Communications Workers of America v. Beck, 487 U.S. 735, 752 (1988) the Supreme Court held that the Railway Labor Act (RLA) and the NLRA were statutory equivalents, thus spawning disputes about when the NLRA case is analogous to a RLA case so as to come within the Supreme Court's decision in Ellis v. Railway Clerks, 466 U.S. 435 (1984). Cal. Saw \& Knife Works, 320 N.L.R.B. at 225. Some cases consider whether standards applied for the RLA should also apply to Taft-Hartley labor unions. See, e.g., Roger C. Hartley, Constitutional Values and the Adjudication of Taft-Hartley Act Dues Objector Cases, 41 Hastings L.J. 1, 12 (1989). About 5\% of the cases in the dataset concern applicability of the RLA.

234. See Hartley, supra note 233, at 11-13.

235. See, e.g., Murphy Oil U.S.A., Inc., 361 N.L.R.B. 774, 791-92 (2014) (comparing NLRA and Title VII and Americans with Disabilities Act); San Manual Indian Bingo \& Casino, 341 N.L.R.B. 1055, 1058 (2005) (same).

236. See supra Part II.B.

237. See, e.g., Oakwood Healthcare, 348 N.L.R.B. 686, 688 (2006) ("[S]ince canons of statutory interpretation caution us to eschew a construction that would result in redundancy, we start from the premise that each supervisory function is to be accorded a separate meaning.").

238. Lincoln Lutheran of Racine, 362 N.L.R.B. 1655, 1657-58 (2015). 
an express requirement that there be "written agreement." 239 The Board reasoned that "Congress' explicit decision to condition the lawfulness" of another activity on a "written agreement with the employer" and the "conspicuous absence of this requirement" in another statutory section demonstrates that "Congress did not intend the viability of a dues-checkoff arrangement to depend on the existence of an unexpired collective-bargaining agreement." 240 The Board went on to chide the prior Board for ignoring the statutory language of two other sections of the statute which were "enacted by the same Congress at the same time" that treated dues checkoffs "quite differently." 241 As the Board states, "[t]he language of the ... proviso makes clear that when Congress wanted to make an employment term, such as union security, dependent on the existence of a contract, Congress knew how to do so." 242 The Board buttressed its analysis with policy arguments and legislative history. ${ }^{243}$

Finally, the Board often relies on any of the substantive canons, a finding contrary to what Krishnakumar finds in her study of the Roberts Court. ${ }^{244}$ The Board often uses two substantive rules that deal the relationship between the Board and Congress. In $7 \%$ of cases, the Board expressly notes that Congress failed to "clearly state" that one interpretation is intended, and so, by implication, the opposite interpretation must stand. ${ }^{245}$ Further, in $8 \%$ of cases, the Board infers congressional inaction as indicating legislative acquiescence of the way the Board interpreted the statute in prior decisions. For instance, in its 2004

239. Id. at 1657 ("Congress' treatment of employer payments to employee trust funds [in another provision of the statute] further illustrates that Congress contemplated that dues-checkoff arrangements could survive contract expiration.”).

240. Id.

241. Id. at $1660-61$.

242. Id. at 1661 .

243. Id. at 1660 n.17 ("[T] that dues checkoff should be included with the overwhelming majority of terms and conditions of employment that remain in effect even after the contract containing them expires.").

244. Cf. Krishnakumar, supra note 10, at 926-27 (finding substantive canons of little use during Roberts Court).

245. See, e.g., United Brotherhood of Carpenters \& Joiners of Am., Local Union No. 1506, 355 N.L.R.B. 797, 806 (2010) (noting that there was "no clear indication ...that Congress intended ... to proscribe" conduct) (internal citations omitted); Alexandria Clinic, P.A., 339 N.L.R.B. 1262, 1265 (2003) (noting that "if Congress had intended to allow either party to extend notice unilaterally, it could have easily done so-but it did not. Instead the Congress carved out a single express exception.") (internal citations omitted). 
Brevard Achievement decision, the Board contends that disabled people are not "employees" under the NLRA because Congress has seemingly been aware of Board decisions on the topic and chose not to adopt legislation modifying the interpretation reached by the Board. ${ }^{246}$

In a handful of cases, the Board invokes the constitutional avoidance canon to guide its decision making. While $6 \%$ of cases in the dataset raise First Amendment concerns, only $2 \%$ of cases expressly invoke the constitutional avoidance canon. ${ }^{247}$ An employer may argue that a statement it made is protected free speech, and the Board in some instances uses the constitutional avoidance canon to guide its determinations so as to avoid dealing with the issue. In one case, the Board invokes the Native American sovereignty canon, particularly in cases concerning the NLRB's jurisdiction over Native American casinos. ${ }^{248}$ Under this substantive canon, a statute should be interpreted so as to guard Native sovereignty. ${ }^{249}$ The Board has also applied the principle against interpreting a statute so as to extend beyond the territorial boundaries of the United States in one case. ${ }^{250} \mathrm{In}$ terestingly, in these cases the majority adopted a policy-based approach, while the dissent argued that the substantive canon should apply to reach the opposite result.

\section{NLRB's Use of Legislative History}

Majority Board decisions frequently invoke legislative history. Almost a third of the decisions in the dataset refer to legislative history at least in part, with legislative history playing a primary part in the majority's interpretation in about a fifth of the cases. The Board relies on a mix of legislative materials. I code for five sources of legislative history: (1) conference committee reports (often considered to be the most authoritative source

246. Brevard Achievement Ctr., Inc., 342 N.L.R.B. 982, 988 (2004).

247. For example, in United Food, the Board notes that it wants to interpret the statute to avoid constitutional collisions with the First Amendment. See United Food, 334 N.L.R.B. 852, 854-57 (2001).

248. In San Miguel Indian Bingo, the Board's rules on whether the NLRB can exercise jurisdiction over Native American casinos, discussing in part the canon against construing legislation against Native Americans. See San Miguel Indian Bingo \& Casino, 341 N.L.R.B. 1055, 1066-70 (2004).

249. Id.

250. See, e.g., Asplundh Tree Expert Co., 336 N.L.R.B. 1106, 1107 (2001) (asserting jurisdiction); Int'l Longshoreman Ass'n, 313 N.L.R.B. 412,417 (1993) (asserting jurisdiction). 
of legislative history);251 (2) House or Senate Committee reports; (3) statements by sponsors, conference chairman, committee chairman or other Congressman in the Congressional Record or in the legislative history; (4) general references to the legislative or amendment process, including references to the 1959 and 1974 amendment processes; and (5) indirect or direct references to legislative history noted in Board, circuit court, or Supreme Court caselaw or law review articles that are cited in the opinion but with no specific citation to a traditional source of legislative history. For example, where a decision simply states, "The legislative history says X," and does not cite to a source, I code the decision as category 5 . However, where a decision refers to legislative history and cites Board or Supreme Court caselaw rather than citing directly to the legislative history, I look to the caselaw to determine how to code the decision. If the caselaw cites directly to one of the other four categories, then I code the decision citing the caselaw as using legislative history in the specific category. If the caselaw contains only a general statement about legislative history that does not include a specific citation to one of the other four categories, then I code the decision as category five.

Figure 10 shows the breakdown of legislative history used in majority opinions based on only the one-third of majority opinions where legislative history was employed. About a third of the citations to legislative history concern broad, indirect references to congressional intent gathered from statements in caselaw or law reviews. This finding may trouble those who advocate for the use of legislative history to aid agencies in interpreting legislation, since it is clear that the Board relies heavily on second-hand sources to garner legislative meaning. Moreover, only $20 \%$ of the citations to legislative history are to what is often hailed as the most authoritative source of legislative intent-conference committee reports. ${ }^{252}$ More often, the Board cites to statements in the congressional committee reports (45\%) or the Congressional Record (39\%). In $41 \%$ of cases employing legislative history, the Board also cites to the amendment process or compares and contrasts bills that may have been defeated in committee or on the

251. Gluck \& Bressman, Part I, supra note 5, at 977.

252. Id. at 976-78; Bruhl, Statutory Interpretation, supra note 83, at 44, 70 (finding that compared to the Supreme Court, district courts cite committee reports as the most cited piece of legislative history). 
floor to ascribe present meaning to a statute. ${ }^{253}$ Although the Board mostly cites to statements by the floor manager or sponsors of the Taft-Hartley Act or its amendments, the Board occasionally also refers to congressional debate, referencing colloquies in the Congressional Record between two Congressman debating different parts of the bill. ${ }^{254}$

Figure 10

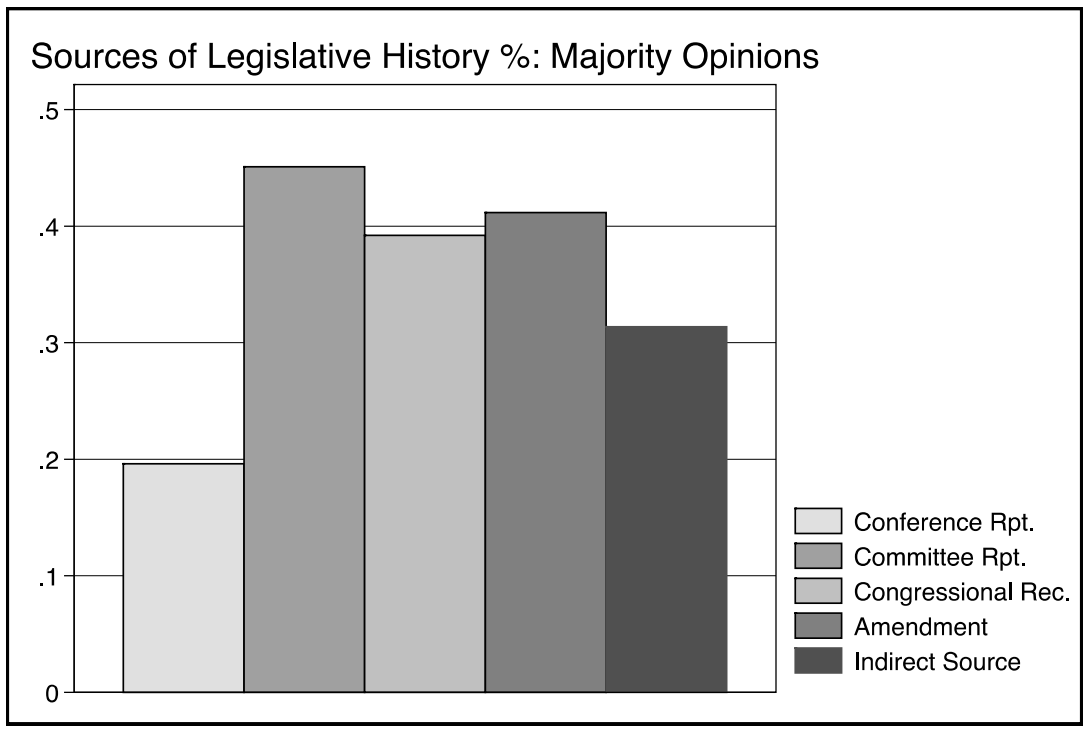

The Board generally invokes legislative history to inform the statute's scope and purpose, make broad references to general congressional purpose or intent, and less often, to simply note that nothing in the legislative history forecloses the majority's given reading of the text. ${ }^{255}$ The cases themselves can be

253. For example, in Alessio Construction, the Board cites to the compromises made in Senate and House bills; the House bill was ultimately adopted. See Alessio Constr., 310 N.L.R.B. 1023, 1027 (1993).

254. See, e.g., Bos. Med. Ctr. Corp., 330 N.L.R.B. 263, 160 (1999) (citing colloquy in Congressional Record).

255. Gluck \& Bressman and Walker similarly find that legislative history helps explain the purpose of the statute, with $80 \%$ of respondents in the Walker survey also noting that legislative history helped define terms. Gluck \& Bressman, Part I, supra note 5, at 971 fig. 7; Walker, Inside Agency, supra note 5, at 1040. As one respondent in the Walker survey put it, "[l]egislative history can help to clarify Congress's purpose in enacting particular provisions, which in turn can help the Agency resolve ambiguities in a way that is consistent with legislative intent." Id. at 1042. 
divided into four different legislative history typologies: (1) legislative history as limiting the text; (2) legislative history as a "plus factor" in informing the statute's scope and purpose; (3) legislative history as not foreclosing a certain interpretation; and (4) legislative history as an irrelevant factor.

\section{a. Legislative History as Limiting the Text}

In a small subset of cases (less than $5 \%$ of cases in the dataset), the Board relies on legislative history as the primary interpretive method. In most of these cases, the Board invokes legislative history to support a narrow interpretation of the NLRA. For instance, in Alessio Construction, 256 the Board invoked legislative history to interpret the meaning of section $8(\mathrm{e})$ of the statute. ${ }^{257}$ The Board looked at the plain text but relied primarily on legislative history to inform the meaning of the statute. ${ }^{258}$ Due to the somewhat temporary and haphazard nature of construction work, Congress carved out an exception to the NLRA regarding the construction industry by giving construction workers (who often can only work in the warmer months) more leeway to engage in boycotts. ${ }^{259}$ The Board held that this exception should be narrowly construed to include only construction practices in existence at the time of enactment-1959.260 The Board reasoned "[a] careful examination of the legislative history of the proviso reveals little affirmative evidence that Congress would have chosen to protect the anti-dual-shop clause if such clause existed in 1959."261 In so doing, the Board selectively included isolated snippets of legislative history, citing some parts and stating that contrary parts were simply irrelevant. ${ }^{262}$ Relying on that narrow slice of legislative history, the Board found the union in violation of the NLRA. ${ }^{263}$ The Board also created precedent for interpreting section 8(e) in accordance with Congress's intent (as revealed by the legislative history) to "preserve the status quo and the pattern of collective bargaining in the construction

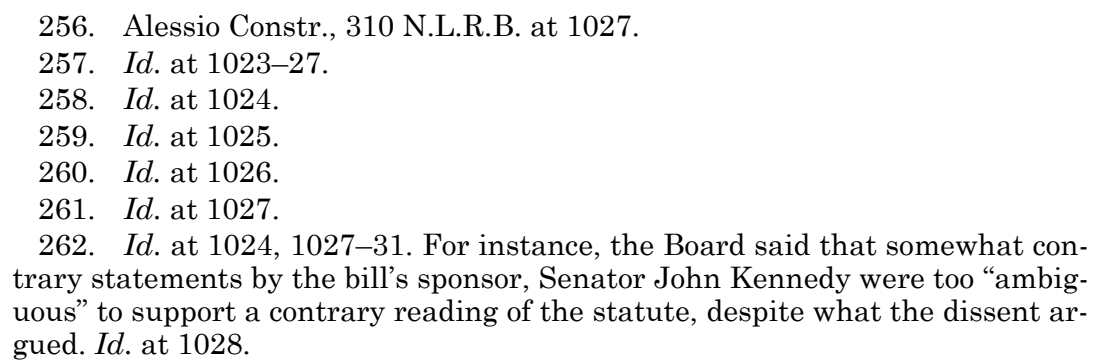

262. Id. at 1024, 1027-31. For instance, the Board said that somewhat contrary statements by the bill's sponsor, Senator John Kennedy were too "ambiguous" to support a contrary reading of the statute, despite what the dissent argued. Id. at 1028 .

263. Id. at 1023 . 
industry at the time the legislation was passed."264 Interestingly, of the cases included in the dataset, only Republican-dominated Boards use legislative history as a limiter to narrowly foreclose relief to the affected party.

\section{b. Legislative History as a "Plus" Factor}

In the vast majority of cases in the dataset in which the Board relies on legislative history, the Board uses it as a "plus" factor to inform statutory scope and purpose beyond what the text dictates. In almost two-thirds of the cases in which the Board cites legislative history, it does so in a non-trivial matter. Moreover, in about a fifth of all cases in the dataset, legislative history serves as a major cornerstone of the analysis. Sometimes, the Board finds that legislative history clarifies ambiguous text while in other cases, the Board relies on legislative history as a "plus" factor in confirming the Board's plain meaning analysis.

For instance, in the Lincoln Lutheran case discussed above concerning whether dues checkoff can survive expiration of the collective bargaining agreement, the Board not only relies on the plain text and Latin/language canons to inform its analysis, but also cites a direct statement of Senator Taft, chairman of the Senate Labor Committee. In a statement made during a debate on the Taft-Hartley amendments, Senator Taft notes that the employer's "obligation may continue indefinitely until revoked." 265 Thus, while legislative history does not form the cornerstone of the Board's analysis, the Board relies on it as further evidence that its interpretation of the Act's scope is reasonable.

\section{c. Legislative History as Not Foreclosing a Certain Interpretation}

In $29 \%$ of cases in the dataset in which the Board invokes legislative history, it does so in a negative way, arguing that since nothing in the legislative history limits the majority's interpretation, the statute must, by implication, be interpreted in a particular way. This particular use of legislative history is perhaps the most troubling. The legislative history of the NLRA

264. Id. at 1027. Specifically, the Board relied on a statement from the House Conference Report that the construction proviso was not meant to "change... the present state of the law" as signifying that the proviso should be interpreted according to the "status quo" of the enacting legislature. Id. at 1028.

265. Lincoln Lutheran of Racine, 362 N.L.R.B. 1655, 1659 n.17 (2015) (citing 93 CONG. REC. 4876, reprinted in 2 NLRB, LEGISLATIVE HiSTORY OF THE LABOR-MANAGEMENT RELATIONS ACT, 1947, at 1311 (1947)). 
spans many pages, so it is a tall order to say that nothing in the entire legislative history contradicts a given interpretation. Nonetheless, the Board often uses this technique to anchor policy-based arguments, perhaps seeking to afford these arguments greater legitimacy by reference to congressional intent.

\section{d. Legislative History as Irrelevant}

Finally, in some cases, the Board wholly ignores legislative history, even if the text is unclear. In Service Employees International Union, 266 the Republican-dominated Board was called on to determine whether a party was a "neutral" under the term's common law definition. In holding that the party was not neutral, the Board found a violation of the NLRA's secondary boycott provisions. ${ }^{267}$ The Board cited extensively to Senator Taft's statements, including his interpretation of the word "neutral" as meaning, "wholly unconcerned" in the disagreement.268 The Board, however, applied a different test, noting that while on its surface, "the legislative history of these provisions would seem to be relatively clear and similarly argue for an extremely narrow interpretation of the term "neutral," policy concerns required a broader interpretation of the statutory term. ${ }^{269}$

\section{NLRB's Use of Precedent}

The Board regularly relies on precedent to inform statutory meaning in almost all of its statutory interpretation cases. When deciding issues of first impression, the Board looks to the $\mathrm{Su}$ preme Court, circuit court, and Board precedent to determine whether anything in prior caselaw constrains the policy choice currently before the Board. In other instances, the Board looks to Supreme Court precedent as an authoritative source to guide the Board in making the right decision to fill the policy hole. For instance, in International Paper, a three-member panel of the Board addressed a question of first impression: whether an employer that has already locked out its bargaining unit and subcontracted work out on a temporary basis can take the further step of subcontracting out work on a more permanent basis. ${ }^{270}$ To answer this question the Board looked to Supreme Court

\footnotetext{
266. Serv. Emps. Int'l Union, 329 N.L.R.B. 638, 639 (1999).

267. Id. at 647,649 .

268. Id. at 640 .

269. Id. (noting that "[a]s clear as the legislative intent may appear, however, its boundaries . . . have consequently produced much additional gloss").

270. Int'l Paper Co., 319 N.L.R.B. 1253, 1254 (1995).
} 
precedent to ascertain whether the scenarios presented were analogous to other scenarios in which such conduct was held to be unlawful. ${ }^{271}$ In this case, the appellate court disagreed with the Board's ruling, finding that it misapplied Supreme Court precedent to arrive at the wrong answer. ${ }^{272}$

Rulings from appellate courts can also prompt the Board to alter policy. In Mississippi Power \& Light, the Board ruled on whether dispatchers are "supervisors" within the meaning of the NLRA. ${ }^{273}$ As part of its reasoning, the Board referenced many other circuit court decisions finding that dispatchers are not supervisors. ${ }^{274}$ Similarly, in Martin Luther, the Board looked to D.C. Circuit precedent for guidance on whether certain work rules chill section 7 rights. ${ }^{275}$ However, in many cases, the Board rejects the guidance of appellate courts, preferring instead to rely on its own precedent or policy considerations, for which it is later chided by appellate courts. ${ }^{276}$

\section{NLRB's Use of Policy and Practical Considerations}

The Board frequently engages in a policy-based approach to inform statutory meaning, with almost half of the cases in the dataset primarily relying on policy as the cornerstone of its choice between two or more permissible constructions of the statute. Another large group of cases relies on policy considerations as a secondary source to buttress the text and/or the text and legislative history. The Board's use of policy-based approaches falls into two main camps: (1) an "all hands on deck" approach where the Board equally looks at text, legislative history, policy, and practical considerations to inform the meaning, with the "purpose" of the statutory scheme occupying center stage in the analysis; and (2) a policy-based approach where the Board either expressly or implicitly decides the case by making a policy choice with little to no discussion of the text or legislative history because there is a discernible "gap" or "hole" in the statute for the Board to fill. In most of the cases in this second category, the

271. $I d$.

272. Int'l Paper Co. v. NLRB, 115 F.3d 1045 (D.C. Cir. 1997) (refusing to enforce Board order, disagreeing with application of Supreme Court precedent).

273. Miss. Power \& Light Co., 328 N.L.R.B. 965, 968-69 (1999).

274. Id. at 969-71.

275. Martin Luther Mem'l Home., Inc., 343 N.L.R.B. 646, 647 (2004).

276. See, e.g., Murphy Oil U.S.A., Inc., 361 N.L.R.B. 774, 780 (2014) (rejecting the guidance of the Fifth Circuit). 
Board rests its analysis on a balancing of competing factors, often citing to precedent to define the factors for consideration. These choices may also include practical considerations, such as whether a given policy will foster inequality in bargaining power, whether it could potentially lead to uproar in the workplace, or whether it is likely to increase the number of strikes in derogation of congressional intent. In all, the majority of cases in the dataset rely on policy considerations as a central element of the analysis, either expressly or implicitly. 277

\section{a. "All Hands on Deck” Purposive Approach}

Under the "all hands on deck" approach, the statute's "purpose" is the central lynchpin of the analysis, with the text and legislative history examined for their ability to shed light on congressional purpose. The issue with this methodology, however, is that both Democratic and Republican Boards premise these arguments on the idea that the Act only has one purpose; they fail to acknowledge let alone reconcile the fact the Act has multiple and somewhat competing purposes. ${ }^{278}$ Framing statutory interpretation in terms of "purpose" thus leads the Board to frequently shift its interpretation of the statute as the partisan majority of the Board changes. In most cases in which the Board adopts this approach, it finds that the text of the statute neither mandates nor forecloses a given interpretation. Legislative history is often of no help as it is used by both the majority and dissent to competing ends, with each side finding something in the legislative history to anchor its policy-based prescription. As such, the Board, unfettered from the text of the statute with only vague references to legislative intent to guide it, can fashion a statutory analysis based on competing policy aims.

For example, in Brown University, the Board ruled on whether graduate TAs qualified as "employees" under the Act. 279 The predecessor case New York University and the subsequent

277. Because much of the Board's interpretation is so caselaw-based it is difficult to tease out exactly how they are interpreting statutes as they cite to $\mathrm{Su}$ preme Court or Board decisions, which in turn have internal citations to statutory interpretation or references to legislative history. Moreover, in about a third of cases in the dataset, the Board opines on the practical implications of its rulings, such as the impact imposing a strict deadline will have on striking words if they strictly read the text. See Alexandria Clinic, P.A., 339 N.L.R.B. 1262, 1262 (2003).

278. Fisk \& Malamud, supra note 20 , at 2020.

279. Brown Univ., 342 N.L.R.B. 483, 483 (2004). 
case Columbia University both apply a textualist approach, looking at the plain meaning of the statute. In Brown University, the Republican-majority Board also adopted a textualist approach but framed its decision largely in terms of congressional purpose. ${ }^{280}$ The Board opined that the NLRA's fundamental purpose is to cover "economic relationships." 281 Because collective bargaining by students at schools does not further the purpose of the Act as intended by Congress, the Board held that graduate TAs are not employees. ${ }^{282}$ The Board also reasoned that to include TAs within the ambit of the Act infringes upon academic freedom. ${ }^{283}$ By contrast, in Columbia University, the Board adopted am "all hands on deck" approach, using textualism, legislative history, policy, and practical considerations to give meaning to the statute. ${ }^{284}$ It too adopted a text-based purposive analysis, but the Democratic-dominated Board conceived of a different statutory purpose than the Republican-majority Brown University Board. As the Columbia University Board reasoned, "[p]ermitting student assistants to choose whether they wish to engage in collective bargaining - not prohibiting it-would further the Act's policies." 285

The Board also used this approach in deciding whether medical residents qualify as employees under the NLRA. In Boston Medical Center, the Board relied on a multi-factor analysis, using text, legislative history, policy, and pragmatic considerations. ${ }^{286}$ The Board emphasized the text, noting the language of the NLRA is broad, and that the term "employee" specifically "include[s] any employee."287 It went further to discuss residents' job functions in light of the dictionary definition of employee. ${ }^{288}$ The Board then looked at other statutory language, such as section 2(12)(b). ${ }^{289}$ The Board buttressed its conclusion by referring to legislative history. ${ }^{290}$ Finally, the Board looked to caselaw, policy and pragmatic considerations. ${ }^{291}$

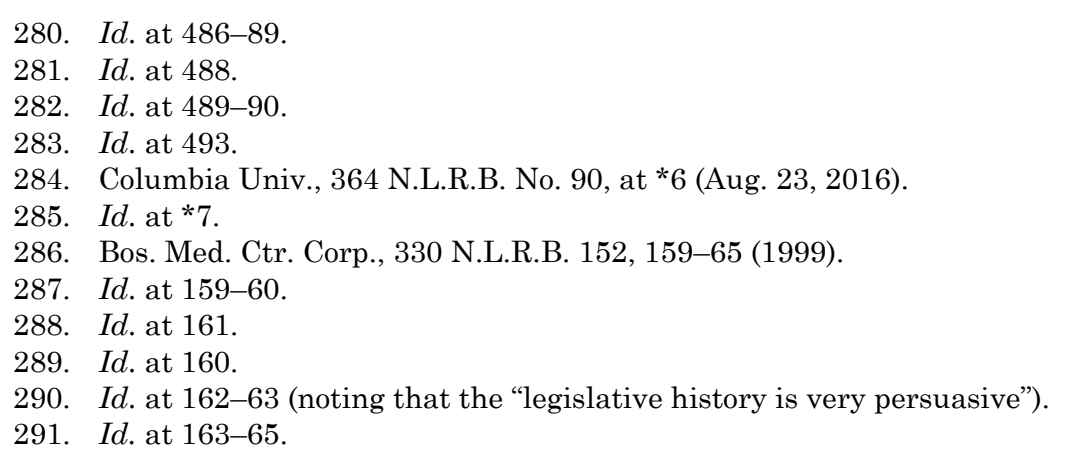




\section{b. Balancing Policy Concerns}

In other cases, the Board largely rests its decision on policy, eschewing text and legislative history in its analysis. These cases involve a clear gap in the law never contemplated by the enacting Congress or addressed in any significant way in the legislative history. For example, the Board applies a completely policy-driven, purposivist approach in Browning-Ferris Industries, in which the Board adjusts the standard for determining whether an entity qualifies as a "joint employer." 292 The Board stated that it was adjusting the test for determining joint-employer status to "best serve the Federal policy of "encouraging the practice and procedure of collective bargaining." 293 In so doing, the Board looked to modern realities of how the prior test had been implemented in practice, and decided to adopt a broader standard so as to effectuate the Act's purpose of facilitating collective bargaining. ${ }^{294}$ The Board noted that the nature of the workplace has changed, citing statistics from the Bureau of Labor Statistics detailing the prevalence of temporary and subcontracting arrangements. ${ }^{295}$ Failure to broaden the standard, the Board argued, would amount to an abdication of its responsibilities to "adapt the Act to the changing patterns of industrial life." ${ }^{296}$ Citing Supreme Court caselaw dictating that the Board should follow the common law agency test in determining employment relationships, the Board reasoned that the NLRA did not foreclose the Board from adopting the broader standard. 297 As the Board argued "reevaluating doctrines, refining legal rules, and sometimes reversing precedent are familiar parts of the Board's work - and rightly so."298

Similarly in Auciello Iron Works, the Board made a policy choice buttressed by Board and Supreme Court precedent. ${ }^{299}$ In

292. Browning-Ferris Indus. of Cal., Inc., 362 N.L.R.B. No. 186, at *2 (Aug. $27,2015)$.

293. Id.

294. Id.

295. Id. at * 15 .

296. Id.

297. Id. at *17.

298. Id. at *24. The Board cites to the Supreme Court in noting that "[t]he use by an administrative agency of the evolutional approach is particularly fitting. To hold that the Board's earlier decisions froze the development ...of the national labor law would misconceive the nature of administrative decisionmaking." $I d$. (internal citations omitted).

299. Auciello Iron Works, Inc., 317 N.L.R.B. 364, 369 (1995). 
that case, the Board ruled on whether the employer could present evidence of its good faith doubt as to the level of the union's majority support. 300 The First Circuit remanded the case to the Board to provide "policy guidance" and to address caselaw from other circuits. ${ }^{301}$ The Board reasoned that both policy and "practicalities support the rule that, if an employer is aware of objective evidence to support a good-faith doubt before the union accepts its offer [to bargain in good faith], it must, for the defense to be timely raised, act on this doubt before the union accepts its offer." 302

\section{Conclusions About NLRB Majority's Use of Statutory} Methods

The Board uses a mix of methods to interpret statutory terms. While policy concerns and precedent predominate in informing statutory meaning, the Board also engages in more traditional statutory interpretation processes, relying on the plain meaning of the text itself, and on how the text relates to other parts of the statute or code. Moreover, the Board frequently invokes legislative history, but such invocation has been somewhat uneven. Majority Boards cite to widely varying sources of legislative history, ranging from conference reports to statements in the Congressional Record. In many instances, however, the Board simply pronounces that the legislative history supports one thing or another, often without any citation except to caselaw.

All in all, Republican-dominated Boards as a whole are no more likely than Democratic-dominated Boards to engage in a textualist approach, and Democrats are no more likely to be purposivists than Republican-majority Boards. While there are intriguing partisan patterns, ideology does not seem to dictate methodological choice to any great extent. Rather, the analysis indicates that Board members selectively use statutory methods of interpretation to advance legal or policy objectives. The eclecticism uncovered by Gluck and Posner in the judicial context seems to be equally true for administrative adjudication, at least with respect to the NLRB. ${ }^{303}$

Certain statutory methods seem to change over time. Decisions based on policy or a mix of text and policy have increased

300. Id. at 364 .

301. NLRB v. Auciello Iron Works, Inc., 980 F.2d 804, 813 (1st Cir. 1992).

302. Id. at 812 .

303. Gluck \& Posner, supra note 91, at 1330. 
over time while use of precedent has declined. Use of legislative history as a primary interpretive source has decreased over the years since the Clinton administration, a trend that Walker found as well among his survey respondents, although it is often used to support a textual or policy-based argument. 304

The Board frequently refers to the whole text, whole act, or whole code rules, though not by name, in a third of its statutory interpretation cases. That the Board often interprets words consistently throughout a statute may be problematic. Respondents in the Gluck and Bressman survey note "significant organizational barriers that the committee system, bundled legislative deals, and lengthy, multidrafter statutes pose to the realistic operation of these rules." 305 While "consistent usage" of a similar term may be the "goal," in reality, Congress often fails to achieve this. ${ }^{306}$ Moreover, in a small but significant number of decisions, the Board interprets congressional inaction as signaling congressional acceptance of its decisions; ${ }^{307}$ given the somewhat uneven nature of congressional oversight, this assumption may be problematic. Thus, in construing the text, the Board may believe that the NLRA was written with greater internal consistency than it actually was and that Congress operates with more intention than it actually does.

\section{D. "DUELING" STATUTORY INTERPRETATIONS}

Almost three-quarters (70\%) of the Board majority decisions in the dataset include a dissent. The dissent "teams" are somewhat consistent. During the Clinton administration, Board members J. Peter Hurtgen and J. Robert Brame often united in dissent, whereas during the Bush II administration, Wilma

304. Walker finds that many rule drafters commented on the declining usefulness of legislative history. Walker, Inside Agency, supra note 5, at 1040. As one respondent in his survey notes: "Legislative history is sometimes useful, but it is becoming less so. Congress puts less time into drafting legislative history that is useful to interpretation of the statute and leaving more of the work to agencies. The administrative rulemaking process is taking on a larger role in shaping the rules that actually apply to the country." Id.

305. Gluck \& Bressman, Part I, supra note 5, at 936.

306. Id. at 937 .

307. See, e.g., Brevard Achievement Ctr., Inc., 342 N.L.R.B. 982, 988 (2004) (noting that "[a]lthough Congress has not hesitated to correct the Board in the past when it has departed from applying the Act as Congress intended it, it has not done so here"); San Manuel Indian Bingo \& Casino, 341 N.L.R.B. 1055, 1058-59 (2004) (interpreting defeated effort as meaning that there was "no indication that Congress intended to exclude tribal enterprises from the Act"). 
Liebman and Dennis Walsh regularly dissented from the majority. In the Obama years, Republicans Philip Miscimarra and Harry Johnson frequently wrote long detailed dissents. The proclivity to dissent has increased over time; whereas Board members dissent in just $58 \%$ of the statutory interpretation cases in the dataset during the Clinton administration, the number of dissents rises to $83 \%$ and $88 \%$, respectively, during the Bush II and Obama administrations.

Section II.D.1 briefly provides the general background of the methods used by dissenting members, followed by a detailed assessment in Section II.D.2 concerning the extent to which the majority and dissenting Board members use either similar or conflicting methodologies in interpreting statutory terms. Board members may "duel" with each other in a textual matter by (1) focusing on different words; (2) focusing on the text of different statutes or alleging a conflict between the NLRA and a given statute; or (3) focusing on the same word but ascribing a different meaning to the term. ${ }^{308}$ Purposivists can also "duel" with each other by (1) focusing on different, competing purposes; (2) focusing on the same purpose but drawing different conclusions about that purpose; or (3) focusing on a broad, general statutory purpose while the competing opinion focuses on narrowly drawn specific purposes. ${ }^{309}$

\section{Methodologies Used in Dissents}

Majority and dissenting Board opinions use similar interpretive methods, as shown in Table 3 and Figure 11 detailing the primary interpretive method used by dissents. Percentages are within a few points of the numbers provided previously for majority opinions. Dissenting opinions tend to rely less on precedent than majority opinions do (29\% v. $36 \%$ in majority opinions). Policy considerations form the cornerstone of $43 \%$ dissenting opinions, a slight increase from the $39 \%$ of majority opinions who rely primarily on policy, and a smaller share of dissenting opinions use legislative history compared to majority opinions. The use of text plus is slightly more common in dissenting opinions.

308. Krishnakumar, supra note 10, at 961.

309. Id. at 971 . 
Table 3: Primary Method of Statutory Interpretation: Dissenting Opinions (Percents)

\begin{tabular}{lccccc} 
& Text+ & Plain & L.H. & Prec. & Policy \\
\hline All Cases & 22.9 & 4.2 & 1.0 & 28.8 & 43.2 \\
\hline Case Type & & & & & \\
Employer & 18.8 & 3.1 & 1.6 & $37.5^{*}$ & 39.1 \\
Union & 35.7 & 0.0 & 0.0 & $35.7^{*}$ & 28.6 \\
Election & 25.0 & 7.5 & 0.0 & $12.5^{*}$ & 55.0 \\
\hline Maj. Party & & & & & \\
Republican & 19.5 & $1.3^{*}$ & 0.0 & 29.9 & 49.4 \\
Democratic & 31.6 & $10.5^{*}$ & 2.6 & 21.1 & 34.2 \\
\hline Adm. & & & & \\
Clinton & 14.3 & 0.0 & 0.0 & 36.7 & 49.0 \\
Bush II & 27.5 & 7.5 & 2.5 & 27.5 & 35.0 \\
Obama & 31.0 & 6.9 & 0.0 & 17.2 & 44.8 \\
\hline Party/Adm. & & & & & \\
Rep./Clinton & $8.1^{*}$ & 0.0 & 0.0 & 32.4 & 59.5 \\
Dem./Clinton & 44.4 & 0.0 & 0.0 & 33.3 & 22.2 \\
Rep./Bush & $23.1^{*}$ & 0.0 & 0.0 & 46.2 & 30.8 \\
Dem./Bush & 29.6 & 11.1 & 3.7 & 18.5 & 37.0 \\
Rep./Obama & $33.3^{*}$ & 3.7 & 0.0 & 18.5 & 44.4 \\
Dem./Obama & 0.0 & 50.0 & 0.0 & 0.0 & 50.0 \\
\hline Statistically sigmiffir
\end{tabular}

*Statistically significant at least $95 \%$ confidence. There were no applicable Republican-minority panels during the Obama administration.

Figure 11

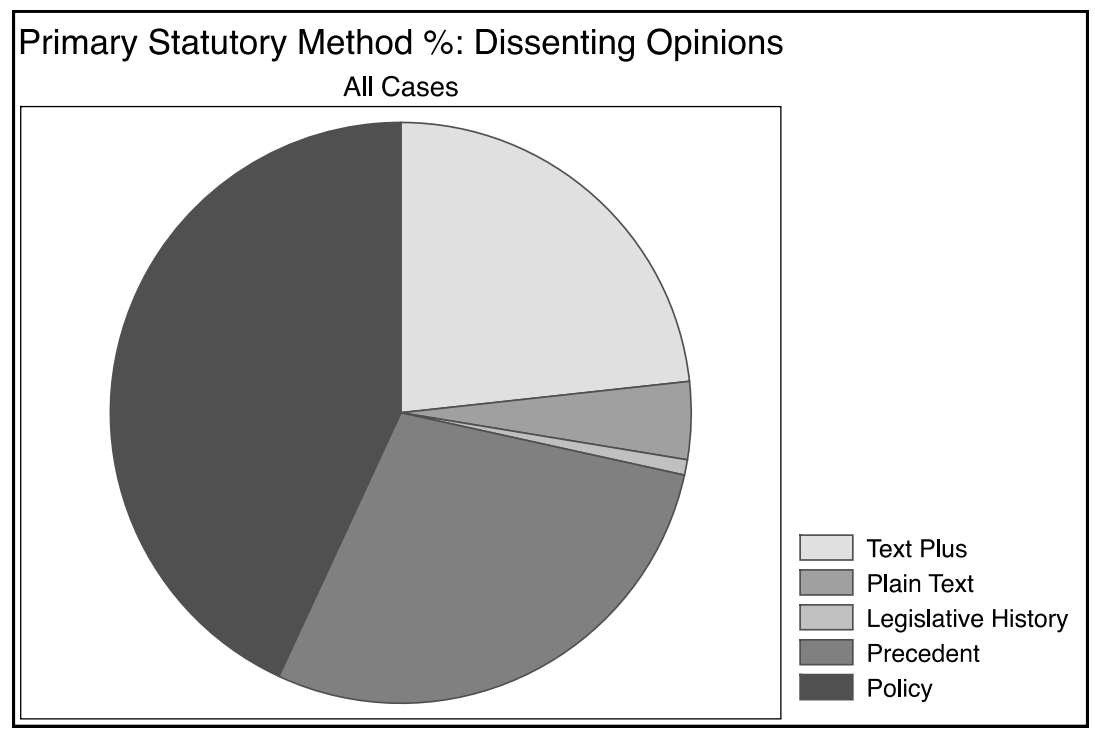


Table 3 details the primary interpretive method used in dissenting opinions, broken down by case type, political party of the dissenters, and presidential administration. There are some noticeable changes compared to majority opinions in Table 1. Use of the text-plus method increased over time, particularly for Republican-minority dissenters; Republican dissenters used text plus $8 \%$ during the Clinton years, 23\% during Bush II years, and $33 \%$ during the Obama years-a statistically significant increase. Republican-minority dissenters differed statistically from Democratic-minority dissenters in the use of plain text as a primary method to a statistically significant degree $(1 \% \mathrm{v}$. $11 \%)$. Dissenters during the Clinton administration relied on precedent in over a third of their dissents in the 1990s, but by the Bush administration, they began to eschew precedent, engaging in more text-based debates with the majority, with only $17 \%$ of cases using precedent as the primary method in the Obama years. This decline occurred among both Democratic and Republican-minority dissenters. Further, the use of policy as the main interpretive tool for dissenting opinions declined during the Bush II administration, picking up again during the Obama administration. As with majority opinions, use of method differed by case type to a statistically significant degree; whereas $38 \%$ of employer cases and $36 \%$ of union cases used precedent as the primary interpretive method, only $13 \%$ of cases involving elections or bargaining unit determinations used this method.

\section{Dueling Interpretations in the Majority and Dissent}

By necessity, the statutory method used by the dissent may in part depend on the statutory method employed by the majority. I code cases according to one of seven "dueling" possibilities: (1) textual to purposivist/policy (that is, the majority opinion is primarily textual, but the dissenting opinion is more purposivist/policy); (2) purposivist to textual; (3) policy, indicating that the majority and dissent "duel" primarily over how to balance a given policy, with the majority favoring one policy aim while the dissent favors another; (4) textual to textual, meaning that the majority and dissent both adopt a textual interpretation, but they differ as to what the text means; (5) debates about the use of precedent, with both the dissent and majority advancing different caselaw to make their case; (6) disputes about which statute to apply; and (7) debates about everything, including text, precedent, policy, and practical implications, and where applica- 
ble, legislative history. In many opinions, majority and dissenting Board members bicker over more than one of these things; they may quarrel over the breadth of the text, the wisdom of using legislative history, which precedent to apply, and what the policy and practical implications will be of a given ruling.

Table 4 and Figure 12 details the percentages broken down by the primary type of "duel." The most frequent "duels" concern disputes between the majority and dissent disagreeing on almost everything, including text, precedent, policy, practical implications, and if applicable, legislative history; $2 \%$ of the dispute concern disputes about everything. Debates also often concern precedent (26\%) or policy (40\%). It can be difficult to separate the two; a debate about precedent may implicitly be a debate about policy. For purposes of this analysis, dueling opinions are coded as centering on precedent if the two sides quarrel over which precedent to apply. Dueling opinions are coded as centering on policy where the Board is called on to make a policy choice to fill a noticeable gap in the statutory scheme. In some cases, the opposing sides debate whether the Board should adopt a new rule. In other cases, one side argues that precedent controls the outcome while the other side reasons that the case should be decided according to text, policy, and/or legislative history.

Table 4: Dueling Statutory Methods: Comparing Majority and Dissenting Opinions on Primary Statutory Method (Percents)

\begin{tabular}{lccccccc} 
& $\mathbf{T}>\mathbf{P}$ & $\mathbf{P}<\mathbf{T}$ & $\mathbf{T}>\mathbf{T}$ & Prec. & Policy & Statute & All \\
\hline All Cases & 3.4 & 3.4 & 1.7 & 26.3 & 39.8 & 2.5 & 22.9 \\
\hline Case Type & & & & & & & \\
Employer & 3.1 & 1.6 & 0.0 & $37.5^{*}$ & 37.5 & $0.0^{*}$ & 20.3 \\
Union & 7.1 & 0.0 & 7.1 & $7.1^{*}$ & 21.4 & $21.4^{*}$ & 35.7 \\
Election & 2.5 & 7.5 & 2.5 & $15.0^{*}$ & 50.0 & $0.0^{*}$ & 22.5 \\
\hline Maj. Party & & & & & & & \\
Republican & 5.0 & $10.0^{*}$ & 2.5 & 30.0 & $27.0^{*}$ & 2.5 & 22.5 \\
Democratic & 2.6 & $0.0^{*}$ & 1.3 & 24.4 & $46.2^{*}$ & 2.6 & 23.0 \\
\hline Adm. & & & & & & & \\
Clinton & 2.0 & 2.0 & 2.0 & 36.7 & 42.9 & 2.0 & $12.2^{*}$ \\
Bush II & 5.0 & 7.5 & 2.5 & 22.5 & 35.0 & 2.5 & $25.0^{*}$ \\
Obama & 3.5 & 0.0 & 0.0 & 13.8 & 41.4 & 3.5 & $37.9^{*}$ \\
\hline Party/Adm. & & & & & & & \\
Rep./Clinton & 8.3 & 8.3 & 0.0 & $58.3^{*}$ & 8.3 & 0.0 & 16.7 \\
Dem./Clinton & 0.0 & 0.0 & 2.7 & 29.7 & 55.1 & 2.7 & $10.8^{*}$ \\
Rep./Bush & 3.6 & 10.7 & 3.6 & $17.9^{*}$ & 35.7 & 3.3 & 25.0 \\
Dem./Bush & 8.3 & 0.0 & 0.0 & 33.3 & 33.3 & 0.0 & $25.0^{*}$ \\
Rep./Obama & 0.0 & 0.0 & 0.0 & 0.0 & 0.0 & 0.0 & 0.0 \\
Dem./Obama & 3.5 & 0.0 & 0.0 & 13.8 & 41.4 & 3.5 & $37.9^{*}$ \\
\hline * Statistically
\end{tabular}

*Statistically significant at least $95 \%$ confidence. There were no applicable Republican-minority panels during the Obama administration. 
Figure 12

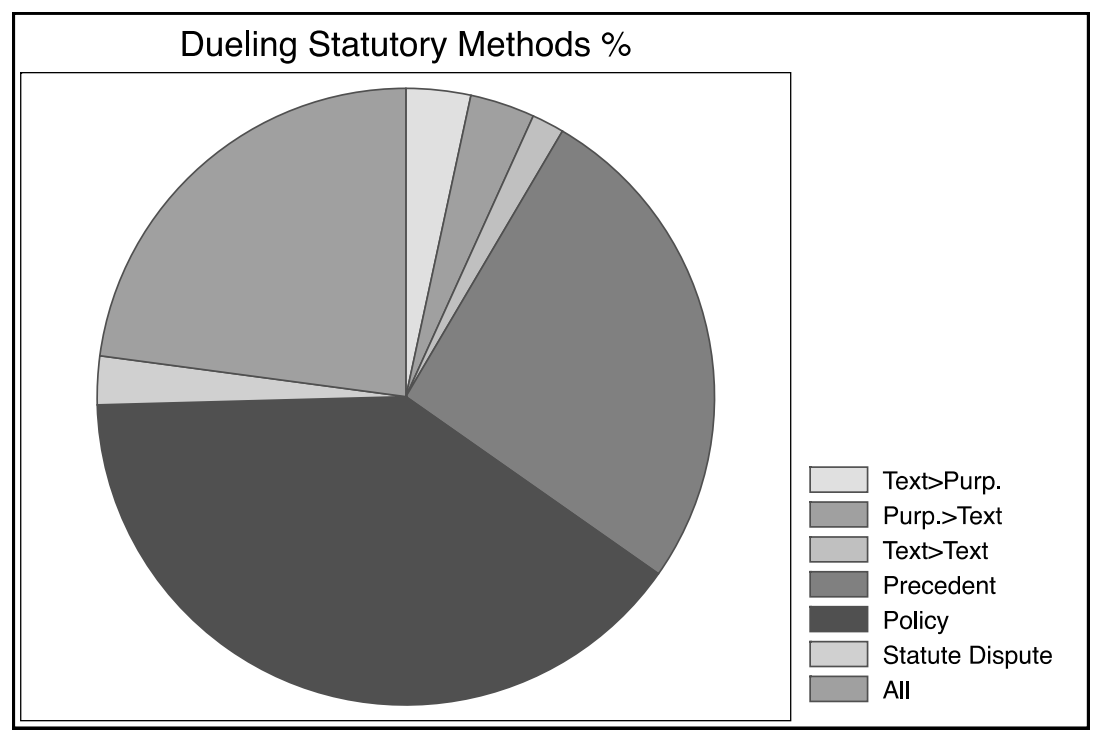

On occasion, the majority and dissent also debate over how the text should be interpreted. Majority and dissenting opinions quarrel over whether the text should be interpreted in an expansionist or narrow fashion in about a quarter of cases. In $5 \%$ of cases, the majority and dissent specifically debate the applicability of the whole text, whole act, or whole code rules (though they are not referred to by name). ${ }^{310}$ In $3 \%$ of cases, the majority and dissent quarrel over which statute takes precedence where there is a conflict between the NLRA and another statute. ${ }^{311}$

These numbers are similar when broken down by case type, with some interesting differences as shown in Figure 13. Policy duels are most common in cases against employers and cases involving elections or bargaining units. Employer cases are by far the most frequent, so the Board already has a great deal of precedent to rely on, and there is little need for new textual interpretation. For election cases, there are often few rules so the Board must devise them. Moreover, there is not much legislative his-

310. See, e.g., Lincoln Lutheran of Racine, 362 N.L.R.B. 1655, 1658-62 (2015) (majority and dissent debating applicability of section 302(c)(4)).

311. This is why we see the sharp uptake up to $21 \%$ in election cases under "Statute" in Table 4. These cases primarily concern whether or not to apply the Railway Labor Act. 
tory to review concerning unfair labor practices against employers as they are covered by the Wagner Act, not the newer TaftHartley Act. 312 In almost one-quarter of unfair labor cases concerning union abuses, the majority and dissent quarrel over which statute to apply, a difference that is statistically significant. ${ }^{313}$ Cases alleging employer abuses often involve debates over precedent (38\%), a figure which is statistically significant.

Figure 13

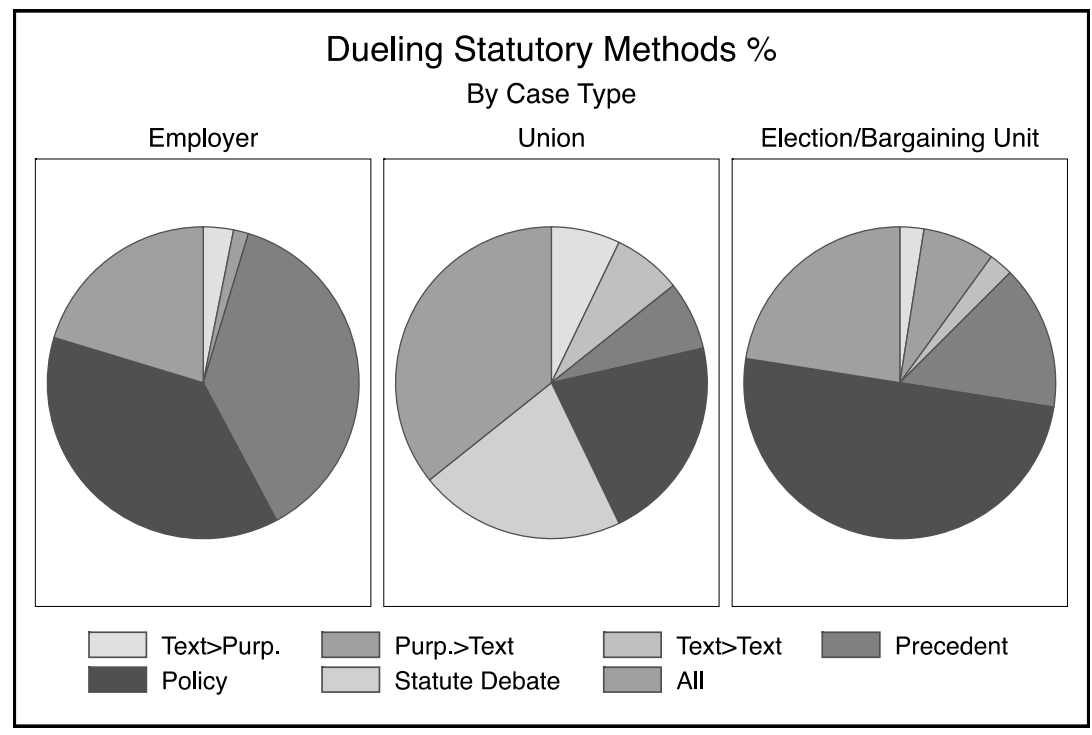

Breaking the data down by the party of the majority and the presidential administration in Figure 14 and Figure 15, the use of policy has increased over time while the use of precedent has decreased, though the differences are not statistically significant. There is a statistically significant increase over time in the use of the last category, debates about everything, from $12 \%$ during the Clinton years to $38 \%$ by the Obama administration. An increase in the use of policy is especially apparent for Republican-majority panels during the Bush II years. Democratic-majority panels more often debate policy than Republican-majority panels, a difference that is statistically significant. Purposive to

312. 29 U.S.C. $§ 158$ (2012).

313. In unfair labor disputes against unions, the Board often "duels" with the dissent over whether the Railway Labor Act should guide its determinations. See supra Part II.C.2.c. 
text debates are also more common for Republican-majority panels than Democratic ones.

Figure 14

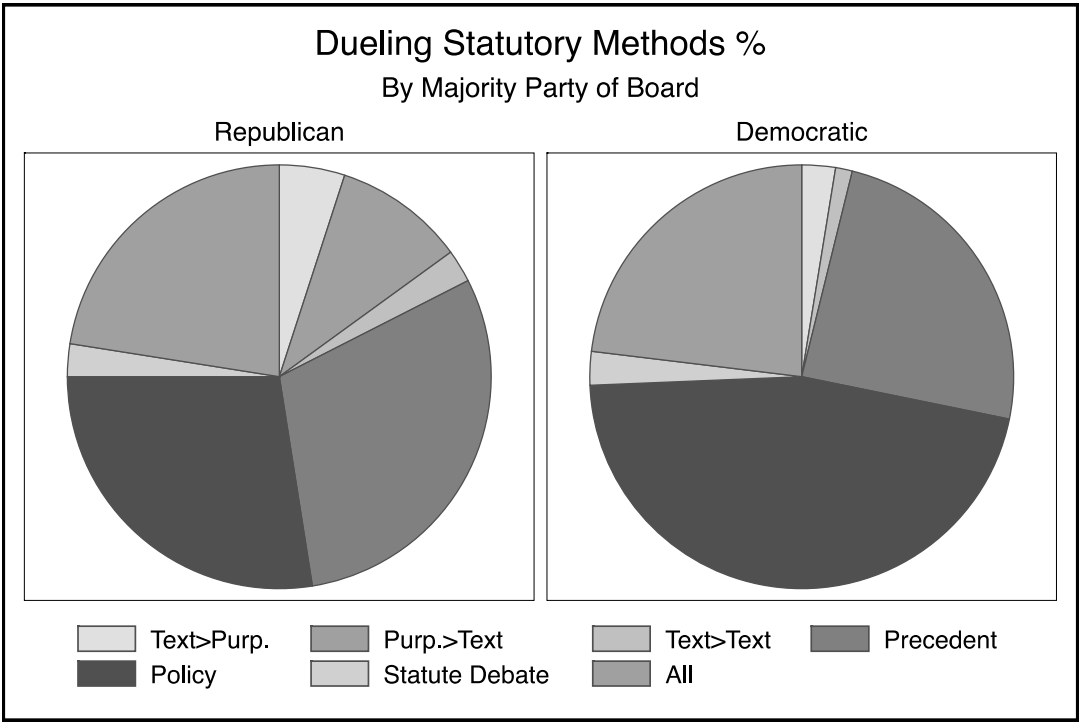

Figure 15

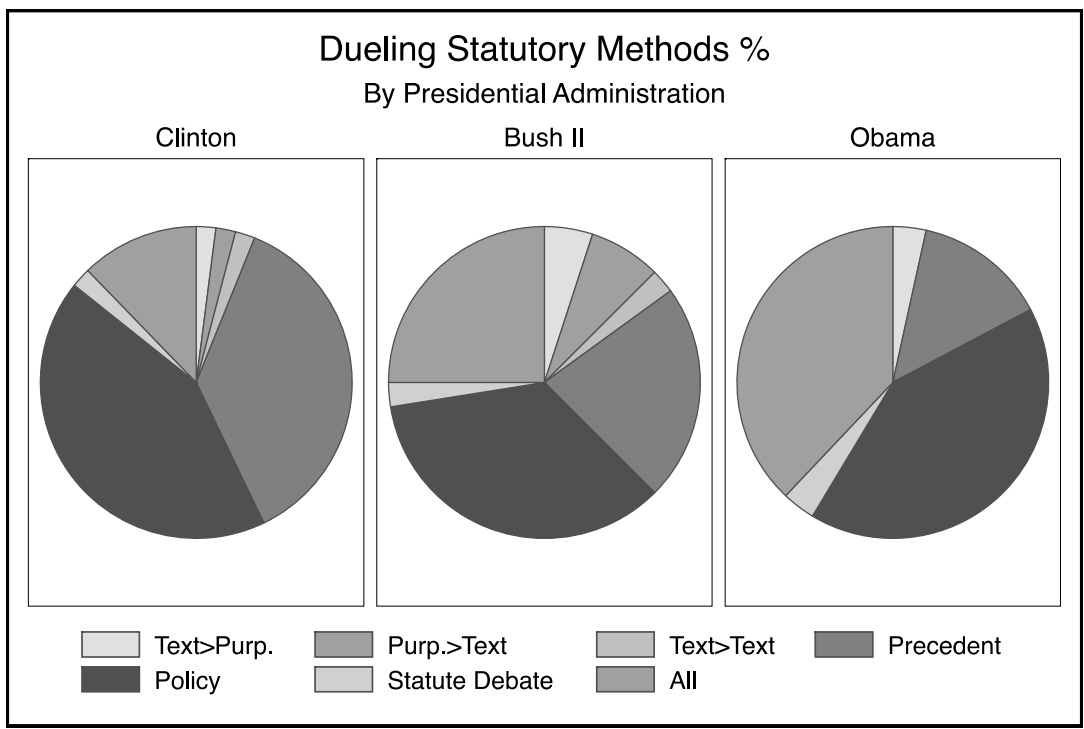


Majority and dissenting Board members also often "duel" on textual meaning, at least in part. In most cases these duels take one of three forms: (1) one side argues for an expansionist interpretation of a term while the other side contends that the term should be interpreted more narrowly, argues that policy considerations should predominate, or suggests that the legislative history demonstrates a congressional purpose that should inform textual meaning; (2) one side argues that certain Latin/language canons should be applied to inform the meaning of the term while the dissent holds the canons inapplicable; or (3) one side finds the text's meaning plain while the other finds it ambiguous.314 For instance, as discussed previously in Alexandria Clinic, P.A., the Republican-dominated Board argues that the text is "clear and unambiguous" and that the Board's reliance on legislative history in the previously-decided Greater New Orleans was inappropriate. ${ }^{315}$ The Democratic dissenters, however, argued that the text is "ambiguous" and "unclear." 316 The three graduate student TA cases likewise show how the Board flipflops, with the majority and dissent following different approaches. Democratic Board members in New York University, Brown University, and Columbia University all favored an expansionist, textual approach, while Republican Board members relied on policy considerations to contend that graduate students were not TAs, arguing that the non-economic nature of the relationship necessitated that TAs fall outside the coverage of the Act. 317

Likewise, majority and dissenting Board members duel over legislative history. In about a third of decisions in the dataset, both sides cite "dueling" legislative history where the majority and dissent cite to different statements in the legislative history to illustrate contrasting points. Again, the nature of dueling over legislative history can take a few forms: (1) one side argues that legislative history informs meaning while the other disputes this characterization; (2) both sides feel legislative history aids in interpretation but they disagree about its purpose or the sources that should be employed; or (3) one side cites to legislative history and the other completely ignores the opposing side's reference to it.

314. See supra Part II.C.2.a.

315. Alexandria Clinic, P.A., 339 N.L.R.B. 1262, 1265 (2003).

316. Id.

317. See supra Part II.C.2.a. 
Both the majority and dissent duel over the use of precedent, especially regarding whether appellate court precedent should govern a given case. In most cases where there is a dissent, the majority cites to caselaw, but the dissent rejects the majority rationale with either a policy argument, or by contending that the text and/or the text and legislative history dictate the outcome. Board members also bicker over the applicable precedent. One side argues that Board precedent applies while the other side contends that either the Supreme Court or the circuit courts should govern the outcome of the case. Further, in a majority of cases involving precedent duels, the Board's battle is internalboth sides agree that Board precedent dictates the outcome, but the two sides quarrel over how the precedent should be applied. In another group of cases, the Board bickers over how to apply Supreme Court precedent. The Board frequently disagrees on whether the Supreme Court's jurisprudence on Railway Labor Act cases should apply to provide insight into a given dispute. ${ }^{318}$ Thus, the malleability of arguments from precedent may suggest that these duels are more accurately characterized as disagreement about policy.

Likewise, majorities and dissents battle over the use of policy. For example, in Alexandria Clinic, P.A., the majority opinion and the dissent battled over the primacy of text over policy. ${ }^{319}$ Although the majority discussed the policy considerations animating its interpretation, it made clear that the text alone was dispositive in finding that the striking nurses had a mandatory duty to give notice under the plain language of the text. ${ }^{320}$ It reiterated the policy argument that Congress deliberately created the notice requirement to be mandatory so as to ensure that a sudden strike did not impair patient health. ${ }^{321}$ The Democratic dissenters, on the other hand, interpreted the Act more loosely, arguing that "[l]ooking beyond the text [of a statute] for guidance is perfectly proper when the result it apparently decrees is difficult to fathom or where it seems inconsistent with Congress' intent." 322 The dissenters thought it "absurd" that Congress "intended to put employees' jobs in peril simply because their union was not absolutely punctual." 323 As such, they advanced a rule

318. See supra Part II.C.2.c.

319. Alexandria Clinic, P.A., 339 N.L.R.B. at 1265.

320. Id. at 1266 .

321. Id.

322. Id. at 1270 .

323. Id. 
of reason approach to guide interpretation of section $8(\mathrm{~g}) .{ }^{324}$ They closed with the notion that "Congress made the policy choice" in advancing a "rule of reason" and as such the Board is duty bound to honor that choice. ${ }^{325}$

Both majority and dissenting opinions also duel over practical considerations. There has been an increase over time in the use of practical considerations to a statistically significant degree. This may be due in part to the fact that the Board has increasingly viewed cases with a more policy-based focus, and as such, the dissents tend to use practical reasoning to attack the policy-based focus of majority opinions. Another reason may be the personal proclivities of members of the Obama Board, as Board members Miscimarra and Johnson frequently wrote long dissents in which they often discussed practical considerations, as one among many reasons for their dispute with the majority.

\section{HOW SHOULD THE BOARD INTERPRET STATUTES?}

The results of this analysis provide support to the Llewellyn view that because canons of interpretation do not constrain voting preferences, Board members may not be basing their decisions on neutral legal principles. ${ }^{326}$ The fact that Board members often use the same statutory methodology to advance opposing outcomes lends support to textualists who bemoan the unpredictability that interpretive canons imply. But the results here undermine the textualist approach as well; few cases can be resolved on the basis of the statute's plain meaning, as the act can be construed broadly or narrowly, producing opposite results. ${ }^{327}$ This leads to the question: How should the Board (and policyoriented administrative agencies in general) interpret statutes? Section III.A addresses some of the pitfalls that agencies face in statutory interpretation. Then, Section III.B analyzes how the results of this study lend further support to the argument that agencies should adopt a more empirically-based method of interpretation. In particular, this Section explores how an empirical approach works in practice at the NLRB, arguing that agencies should leverage their considerable expertise in interpreting stat-

324. Id. at $1270-71$.

325. Id. at 1272 .

326. Krishnakumar, supra note 10 , at 959.

327. James J. Brudney, Isolated and Politicized: The NLRB's Uncertain Future, The National Labor Relations Board in Comparative Context: Introduction, 26 COMP. LAB. L. \& POL’Y 221, 244 n.10 (2005). 
utes using relevant social science data available to them. Finally, the Article makes the case for why rulemaking may be the best vehicle for agencies to advance important statutory interpretation so as to best balance the competing objectives of policy coherence, stability, and democratic accountability.

\section{A. Pitfalls in Construing Statutes Like Courts}

The results of this study underscore problems with agency interpretation of statutes. While scholars have long contended that agencies should interpret statutes differently than courts do, in practice, agencies interpret statutes similarly to courts. In particular, the empirical results of this study point to three potential problems in how the NLRB interprets statutes. First, its reliance on precedent to justify decisions may simply be a veil to disguise policymaking. Second, the Board's overreliance on certain textual canons - in particular the whole text, whole act, and the whole code rules-may result in decisions that bear little relationship to congressional intent about statutory purpose. Finally, the Board's selective use of legislative history-especially when it uses legislative history to limit the text-may result in decisions that stray from statutory purpose.

\section{Use of Precedent to Hide Policymaking}

Agencies may rely too much on precedent created by judicial bodies to assist in interpreting their own governing statutes. In a large percentage of cases in the dataset, the NLRB interprets the statute by cobbling together snippets of caselaw in its "quest for coherence ... to advance[] a narrative that is ... part of the American legal tradition." 328 But using precedent to ground statutory questions of first impression may not be appropriate in the administrative law context. ${ }^{329}$ In addition to the fact that there is rarely one precedent that mandates a given result, law is not as path dependent in the administrative context. ${ }^{330}$ Indeed, Llewellyn noted at least sixty-four ways in which courts can apply prior precedent. ${ }^{331}$ In particular, agencies' citation of federal courts may be especially problematic. ${ }^{332}$ The NLRB may cite a

328. Krishnakumar, supra note 10 , at 1172.

329. See, e.g., Jeffrey A. Pojanowski, Reading Statutes in the Common Law Tradition, 101 VA. L. REV. 1357, 1374 (2015).

330. Solan, supra note 15 , at 1187.

331. Karl N. Llewellyn, The Common law Tradition: Deciding ApPEALS 77-91 (1990).

332. VERMEULE, supra note 12, at 200-02. 
Sixth Circuit case as the basis for its statutory construction, even though that particular precedent has no bearing on parties outside of the Sixth Circuit, and even though the NLRB has long maintained a policy of nonacquiescence to appellate decisions. ${ }^{333}$ Board members should make a distinction between mandatory and merely persuasive authority when basing decisions on precedent. 334

Moreover, there is necessarily a tension between lack of statutory stare decisis and the benefit that inures when the meaning of a statute is settled and can be consistently relied upon. ${ }^{335}$ Adherence to statutory stare decisis may be especially important in cases when it is more important that the law be settled than be settled right. Statutory stare decisis may actually exist on a continuum. According to this theory, stare decisis is most important in constitutional cases, where the legislature lacks an effective means to override a displeasing interpretation, to a "middle ground" in common law adjudication, to possibly an even lower level of deference in agency interpretation cases, where the legislature has numerous means at its disposal to right a statutory interpretation it finds troubling. ${ }^{336}$ If statutory interpretation in administrative adjudications is akin to policymaking, the decision may be best left up to the executive branch, with the judiciary confined to questioning whether the interpretation is reasonable and supported by evidence. ${ }^{337}$

\section{Overreliance on Textual Rules}

In addition, the Board's overreliance on textual canons like the whole text, whole act rule, or the whole code rule may be inappropriate given the realities of statutory drafting. As detailed by the comprehensive study by Gluck and Bressman, false assumptions about the legislative process abound, especially

333. See Estreicher \& Revesz, supra note 152, at 681.

334. See Solan, supra note 15, at 1175.

335. Id. at 1176. Solan cites Justice Louis Brandeis who advocates statutory stare decisis. See Burnet v. Coronado Oil \& Gas Co., 285 U.S. 393, 406-07 (1932) (Brandeis, J., dissenting) ("Stare decisis is usually the wise policy, because in most matters it is more important that the applicable rule of law be settled than that it be settled right." (citation omitted)).

336. See Solan, supra note 15, at 1176.

337. See id. at 777-79. 
with respect to the roles that agencies play in the drafting process. ${ }^{338}$ In practice, agencies have their own terms of art endowed with specific meaning such that reliance on the whole code rule to interpret statutes may be misplaced. ${ }^{339}$ Moreover, interpretation of like terms in the same statute may not be a reliable guide to legislative intent. Gluck and Bressman argue usage may be more consistent across committees overseeing the drafting as opposed to consistency in the act as a whole. ${ }^{340}$ As Gluck argues, "[t]he idea that similar phrases mean the same thing across an entire statute or that variation of terms is meaningful even across multiple statutes does not comport with the structural separation of committees and the lack of communication between them, even when they work on the same statute." 341

This empirical study reveals that the Board frequently uses the whole text, whole act, and whole code rules to interpret the NLRA. As detailed in Part II, the Board often relies on textual interpretation and legislative history of other statutory sections drafted by different Congresses in different time periods to advance a narrative. ${ }^{342}$ The Board also frequently refers to the $\mathrm{Su}$ preme Court's interpretation of an entirely different statutethe Railway Labor Act-to interpret section 8(b) cases. Concern over using the whole text rule may be especially problematic when the Board uses parts of the law directed at union abuses to inform meaning about employer abuses. The legislative history of those sections was written at different times in dramatically different political climates, and as such, the Board should be cautious in extrapolating from one section to another. ${ }^{343}$ More attention to the realities of congressional drafting would do much to improve interpretive assumptions. ${ }^{344}$ In addition, the Board often gives too much credit to Congress. In a small, but substantively significant, number of cases, the Board refers to congressional inaction or Congress's inability to clearly state a

338. See Gluck \& Bressman, Part II, supra note 5, at 801 (showing that Congress often does not abide by assumptions judges make about legislative drafting); Walker, Inside Agency, supra note 5, at 1028-29 (same); see also Gluck, supra note 16, at 179 (setting forth ways in which Congress works differently than assumptions predict).

339. See Shobe, supra note 124, at 518-19.

340. Gluck \& Bressman, Part II, supra note 5, at 746-47.

341. Gluck, supra note 16, at 203.

342. See supra Part II.C.2.c.

343. Fisk \& Malamud, supra note 20, at 2020.

344. Cf. Gluck, supra note 16, at 188 (proposing one such approach to accomplishing this objective). 
rule as being important in how it interprets a statute. ${ }^{345}$ Such assumptions may be misplaced.

\section{Selective Reliance on Legislative History}

Finally, the Board's selective reliance on legislative history-particularly citation of legislative history to limit the clear language of the text-is misplaced. On the one hand, as Peter Strauss argues, agencies may be in a better position than courts to understand and absorb the legislative history. ${ }^{346}$ This may be particularly the case for statutes enacted before the professionalization of Congress began in earnest in the 1960s and 1970s. ${ }^{347}$ Congress did not even have its own internal administrative capacity until the passage of the Legislative Reorganization Act of 1946 and up to that time, House and Senate standing committees had no regular professional staff. ${ }^{348}$ During the time period of the NLRA's drafting, Congressmen and committees were almost completely reliant on the agencies themselves to provide advice on drafting. ${ }^{349}$ Indeed, for many statutes enacted during this period, scholars hypothesize that agencies essentially "ghost-wrote" the statute and/or its legislative history, even going so far as to draft mock debates to put into the Congressional Record. ${ }^{350}$

The Board occasionally uses legislative history to preclude the Board from updating itself to modern times. For instance, why should a provision be interpreted with respect to what the standard was in the construction industry in 1959, a result that some Board decisions argued was shaped by the legislative history? 351 The Board should not use legislative history to wed itself to employment practices of a bygone era. To do so subverts the role of the agency as the living, breathing embodiment of statutory interpretation. Further, all legislative history is not the

345. See supra note 307 and accompanying text.

346. Strauss, supra note 96, at 321.

347. See Nicholas R. Parrillo, Leviathan and Interpretive Revolution: The Administrative State, the Judiciary, and the Rise of Legislative History, 18901950, 123 YALE L.J. 266, 338 (2013) (noting the dearth of professional staff prior to this time).

348. Id. In the 1940s, the House and Senate Office of Legislative Counsel had only five lawyers, a figure seven times less than comparable figures today. Id. at 339 .

349. Id.

350. Id. at 337 .

351. See supra Part II.C.3.a. 
same. In a majority of cases, the NLRB relies on legislative history other than the conference committee markup, which often can be the most "illuminating" part of the legislative history. ${ }^{352}$ Moreover, while some of the statements cited in the cases in the dataset were scripted colloquies-which are often seen as important to demonstrate a "shared agreement about statutory meaning"-most citations were to random statements by a single Congressman in the Congressional Record. 353 This lack of reliance on "consensus legislative history" is troubling since it may not necessarily be indicative of clear congressional intent about statutory purpose. Moreover, the frequent indirect citations to legislative history in the cases in the dataset, with the Board frequently citing to other court decisions that refer to legislative history, underscores the limited utility legislative history may have in informing meaning.

Legislative history can be a useful tool in informing purpose, but the Board at present likely relies too much on legislative history as a shield for disguising policymaking. Instead of looking at the original enacting Congress's purpose, the Board should instead look to the role of the agency in the present world with legislative history as a starting point to inform understanding. The Board should rely more heavily on its current dealings with Congress and the President to inform its vision for contemporary labor policy. Labor policy need not have a fixed and definite framework; the nature of a specialized administrative agency is to change along with the ebb and flow of changing administrations. At the same time, however, the legislative history should serve as an anchor for the agency to base its understanding of the text, as the agency is the "guardian or custodian of the legislative scheme as enacted." ${ }^{54}$ Instead of relying on "text parsing, dictionary definitions, and a search for a fixed intent of the enacting Congress," legislative history should instead be used as the beginning inflection point to examine "policy and expert considerations, pressures from the current Congress or White House, and bureaucratic management concerns." 355

352. Gluck, supra note 16, at 207.

353. Id. at 208.

354. Mashaw, Between Facts and Norms, supra note 4, at 508; see also Walker, Inside Agency, supra note 5, at 1066 ("[F] ederal agencies play a critical role in the legislative process such that rule drafters have the intimate understanding of legislative history that Strauss hypothesized nearly a quarter century ago.").

355. Elizabeth V. Foote, Statutory Interpretation or Public Administration: 


\section{B. PROPOSALS FOR REFORM}

Formulating a normative answer to the question of how agencies should interpret statutes is a question of how one views the role of the administrative state. Should agencies be faithful delegates of the political principals, or should agencies be the "guardians" of the interpretation of the overarching statute? Or does the answer lie in some mixture of the two?

A pure textualist reading of the NLRA seems at odds with the NLRB's structure and purpose. Nearly seventy-five years following its enactment, it seems doubtful that parties would still be litigating issues seemingly clearly decided by the statutory text. If the text itself were the primary criteria for interpreting the NLRB, what would be the purpose of having a specialized body? Why not just have the cases heard in the regular district courts? If the political system is not going to take advantage of the specialized expertise of the NLRB, it seems superfluous for the NLRB to interpret statutes in ways that are inconsistent with its very existence, as Congress wanted to limit the power of courts to rule in labor disputes. ${ }^{356}$ Strict adherence to a text constructed by congressional leaders to curb a labor-friendly Board seventy-five years ago may constrain the Board in how it approaches policymaking and updating labor policy to current economic conditions. ${ }^{357}$ Moreover, a textualist approach seems at odds with the Board's frequent flip-flops on important issues of policy. If the NLRA actually has a clear and unambiguous meaning, once the five-member Board interprets a term, it would be unnecessary for the Board to engage in statutory interpretation of that term again. Frequent flip flops seem only compatible with a purposivist approach. Cass Sunstein and Adrian Vermeule argue that attention to institutional considerations shows why agencies should be given authority to abandon textualism even if the courts use it. ${ }^{358}$ To the extent the Board engages in a textualist approach, it should look to the text to permit a construction, as opposed to a narrowing constraint on policy choices-a method employed in many of the Board's textualist decisions.

How Chevron Misconceives the Function of Agencies and Why It Matters, 59 ADMIN. L. REV. 673, 707 (2007).

356. See Hayes, supra note 131, at 554 (noting that Congress intended to shift policy-making control in this realm from courts to the Board).

357. See O'Gorman, supra note 59, at 200.

358. Sunstein \& Vermeule, supra note 4, at 928; see also Frank H. Easterbrook, The Absence of Method in Statutory Interpretation, 84 U. CHI. L. REV. 81, 96 (2017) (noting that the "[r]ules of interpretation must reflect the resources available to the task"). 
As such, a statutory construction focused on purposivism with a faithful rendering of the text when clear seems to be the only method of statutory interpretation consistent with the purposes, aims, and history of the NLRB, and indeed, administrative agencies generally. ${ }^{359}$ Agencies are in a unique institutional position to best understand the agency's purpose, even when the purpose is conflicting. ${ }^{360}$ Formed during the New Deal, the NLRB is charged to be an expert body to fashion labor policy. Agencies like the NLRB should use that expertise to update their interpretation of the statute to reflect current realities. With changing times and shifting economic winds, the Board, advancing a purposivist approach, is best able to effectuate the purposes and aims of an expert labor body to do what is best for society. 361

This Section proposes three recommendations for reform. First, the Board should use its expertise to buttress its policy arguments with facts. Rather than merely opine that a given decision will have a certain effect on policy, the Board should use empirics to competently evaluate the ramifications of its decisions. Second, the Board should make decisions in line with background principles of substantive law. Third, the time is ripe to discuss whether the Board should engage more in rulemaking to guide statutory decisions.

\section{Leverage NLRB Expertise Grounded in Real-World Implications}

The Board should use its expertise to craft legal doctrine that advances the NLRA's purpose, collecting evidence on policy and pragmatic consequences of a given decision. ${ }^{362}$ As Mashaw argues, "[a]gency control of . . . its interpretive agenda argues for an interpretive approach that engages in a wider-ranging set of policy considerations and a more straightforward approach to political context than would be constitutionally appropriate for the judiciary." 363 At present, the NLRB chooses between "competing constructions... within the range of meanings that the statutory language can support" when interpreting statutes. ${ }^{364}$

359. See O'Gorman, supra note 59, at 200 (noting that a purposivist approach affords more flexibility to adapt to current circumstances).

360. See Herz, supra note 12, at 99, 104.

361. See O'Gorman, supra note 59, at 216.

362. See id. at 215-16; Mashaw, Between Facts and Norms, supra note 4, at 510.

363. $I d$.

364. Pierce, supra note 1, at 200. 
In essence, the conflict boils down to one side advocating that a term be construed broadly with the other arguing for a narrow construction. For instance, in the case of whether graduate student TAs qualify as "employees" under the NLRA, the battle can be stripped down to whether one thinks that the statutory purpose of the NLRA is best effectuated by a broad or narrow reading of the statute. ${ }^{365}$ Traditional methods of statutory interpretation relying on the text or legislative history are of little consequence in answering that question, because the answer boils down to a political calculation of whether the decisionmaker believes the NLRA should be interpreted broadly to cover a wider array of workers in disadvantaged positions. This is more a debate about policy than about textualism.

If the NLRB is truly going to serve its foundational mission, it needs to start acting more like a policymaking court rather than a court who does policymaking on the side. ${ }^{366}$ Board decisions often predict dire consequences of a given decision, yet never lay out the empirical evidence to back it up. For instance, in Browning-Ferris Industries, Board members Miscimarra and Johnson predict that the Board's revamp of the "joint employer" test would wreak havoc on the workplace.367 The dissenters spend page after page bemoaning the negative consequences that would ensue, without offering any social scientific evidence to support these claims. Nor does the dissent include any citations to buttress its claims about the decision's ramifications. In all, the majority and dissent come down to a policy dispute over how broadly to interpret the word "employee." This same pattern —of both the majority and dissent making arguments without empirical evidence regarding the likely consequences of a given decision-is prevalent throughout the statutory interpretation cases studied.

365. See supra Part II.C.2.b.

366. See Fisk \& Malamud, supra note 20, at 2057 ("[T] he Board continues to operate like a court, limiting itself to the specific issues brought to it by the General Counsel, failing to bring multiple areas of Board doctrine together to enrich its understanding and amplify its remedial capacities, and, most of all, using rights rhetoric as a way to mask what would otherwise be its obligation to seek out (let alone generate) empirical assessments of the effects of its policies.").

367. Browning-Ferris Indus. of Cal., Inc., 362 N.L.R.B. No. 186, at *26 (Aug. 27,2015 ). The dissenters continue: "We believe the majority's test will actually foster substantial bargaining instability by requiring the nonconsensual presence of too many entities with diverse and conflicting interests on the 'employer' side." Id. at * 23 . 
The NLRB can be reformed to give it more power to engage in policymaking in a more explicit and fairer way. For instance, if the NLRB were to truly embrace its policymaking role, it would ask parties that appear before it to brief the economic effects that would flow from its decision. Rather than vague assertions of "policy" or pontifications about a given case's possible ramifications, the Board should consider expert opinions so as to have a solid foundation to inform policymaking to serve the aims of (1) avoiding strikes; and (2) increasing wages, the twin aims that Congress states as the underlying purpose of the NLRA.

New Dealers envisioned agencies as expert, professional bodies capable of analyzing social and economic problems and relying on scientific and empirical information that courts and legislatures lack capacity to fully consider. ${ }^{368}$ The Board never developed the kind of non-legal expertise that administrative agencies were supposed to have due to historical circumstances. ${ }^{369}$ In the 1940 s, widespread opposition to the Board resulted in Congress gutting the Board's Division of Economic Research, which had gotten a reputation as being biased towards labor interests. ${ }^{370}$ Further, an early turf war with the Department of Labor (DOL) resulted in the Board not having access to DOL's empirical research on labor. ${ }^{371}$ DOL has the ability to produce "high-quality empirical analyses of the myriad questions that arise in NLRB cases," 372 yet currently the Board has no access to this valuable information. Moreover, the Board is not able to coordinate data gathering and policy analysis with DOL, the Equal Employment Opportunity Commission, or state labor agencies. ${ }^{373}$ Giving NLRB back its policy tools would do much to make its statutory interpretation more reasoned and more consistent.

368. See JAmes M. LANDis, The Administrative Process 38-39 (1938).

369. See Fisk \& Malamud, supra note 20, at 2015. The NLRB states that "[n]othing in this subchapter shall be construed to authorize the Board to appoint individuals for the purpose of conciliation or mediation, or for economic analysis." 29 U.S.C. § 154(a) (2012) (added by Taft-Hartley Act, Pub. L. No. 80-101, 61 Stat. 136 (1947));GROSS, REMAKING, supra note 135, at 225 (recounting the history of Taft-Hartley).

370. See Fisk \& Malamud, supra note 20, at 2048. In the 1940s, Congress held hearings about the NLRB, concerned that the Board was ruling too much in a pro-labor direction. $I d$.

371. Id. at 2049. Labor Secretary Francis Perkins campaigned for the NLRB to be a part of the Department of Labor instead of an independent agency. Id. at 2045 .

372. Id. at 2051.

373. Id. at 2049 . 
Of course, critics of this approach may argue that social science data may itself be tinged with political calculations. Each side could surely hire experts to advance their preferred policy position. However, by creating a nonpartisan body within the NLRB akin to the Congressional Budget Office to offer economic advice on the ramifications of a given decision would do much to leverage the agency's expertise, yielding more stable and consistent decisions.

At present, the NLRB changes its interpretation too frequently with changing political realities. Since 2000, the NLRB has changed its position on whether graduate TA constitute "employees" under the NLRA three times. ${ }^{374}$ While such a change may on occasion be preferential or mandated from a democratic accountability perspective, too much change-especially when such change is not grounded in sound social science data-results in a lack of stability in labor laws. Mandating some empirical evidence to back up claims about policy increases the transaction cost for policy change, making it less likely that agencies make frivolous or unsubstantiated policy changes. But requiring changes in interpretation to at least be minimally grounded in evidence that the decision accomplishes the statute's purpose would do much to ensure that decisions affecting the everyday lives of millions of people are grounded in something more than the ideological preferences of a given presidentially-appointed Board member. Such a requirement would prevent the executive from gaining too much power at the expense of the other branches. In essence, reforming the process to include more voices would be a better alternative than the present system to best balance the goals of policy coherence, stability and democratic accountability.

\section{Ground Statutory Interpretation in Substantive} Background Principles

As part of using its expertise to interpret statutes, agencies should interpret statutes in a way that makes sense in light of background principles of substantive law. ${ }^{375}$ As Jonathan Siegal argues, "this distinctive degree of knowledge puts agencies in a particularly good position to utilize an interpretive method," giving weight to "background principles" to guide interpretation. ${ }^{376}$

374. See supra Part II.C.2.b.

375. See Siegel, supra note 23, at 124 (arguing that agency expertise should lead to reliance on substantive law in statutory interpretation).

376. Id. 
These substantive principles may tilt the result toward a given result, in line with how the law is usually interpreted in similar cases. ${ }^{377}$ For instance, in an environmental law case, in interpreting whether a substance is "hazardous," the EPA may give particular weight to the concentration of the chemical, because of the background principle that concentration is an important consideration in determining whether something is hazardous, even if the statutory text is unclear or ambiguous on the topic. ${ }^{378}$ These "field-specific canons of construction" are based on scientific study ${ }^{379}$ and their usage would ensure that statutes within substantive areas are interpreted consistently and in line with the expertise of the agency.

The NLRB is uniquely positioned to understand the nuances of workplace discrimination and harassment. For instance, in interpreting whether conduct is "protected" under the statute or whether the employer or union acts in a "concerted" fashion, the NLRB can apply background norms of labor laws to elucidate understanding of those terms. ${ }^{380}$ The experience of hearing and ruling on thousands of cases gives the NLRB the unique perspective to understand when employer or union conduct directed at employees is truly egregious enough to warrant reprimand under the NLRA. ${ }^{381}$

3. Use Rulemaking as a Tool to Advance Key Statutory Interpretations

Finally, the Board should change its method of policymaking and rely more on rulemaking or guidance documents to advance statutory directives. ${ }^{382}$ The Board needs to engage in policymaking, and one questions whether an institutional body

377. See id. (suggesting that agency interpretation by this method will make sense in the broader field of relevant law).

378. Cf. id. at 125-28 (explaining the concept of using background legal principles as a tool of statutory interpretation). Siegal cites the case of National Resources Defense Council v. United States Environmental Protection Agency, 907 F.3d 1146 (D.C. Cir. 1990), as an example. Id. at 132-35.

379. Id. at 135 .

380. Cf. id. at 136 (arguing that the EPA is in the best position to apply principles of environmental law).

381. See generally, supra Part II (analyzing the NLRB's extensive body of adjudications).

382. See, e.g., R. Alexander Acosta, Rebuilding the Board: An Argument for Structural Change, Over Policy Prescription, at the NLRB, 5 FLA. INT'L U. L. REV. 347, 359 (2010) (arguing that rulemaking "will help stabilize Board law and restore public and judicial confidence in the agency"); Charlotte Garden, Toward Politically Stable NLRB Lawmaking: Rulemaking vs. Adjudication, 64 
acting like a court can ever really be a reliable policymaking body. ${ }^{383}$ Scholars argue that an agency's statutory interpretation is probably not invariant to forum. ${ }^{384}$ An agency's ability to incorporate political preferences and budgetary concerns into decisions may be improved in rulemaking as opposed to adjudication. ${ }^{385}$ The Board's adjudicatory decisions are so intermixed with policymaking that it is almost impossible for the Board to have any precedent on which to rely, resulting in confusion before the appellate courts, who frequently cite to NLRB caselaw only to find that the NLRB changed its position. ${ }^{386}$

The Board could set up a clearer boundary between policymaking and adjudicatory decisions if it relied more on rulemaking or guidance documents to set forth its policy-fused statutory interpretations. For instance, instead of relying on adjudication to define "employee," the Board could engage in notice-and-comment rulemaking to set forth clear standards regarding who falls within the coverage of the Act. ${ }^{387}$ In so doing, the Board should adopt "evolving, iterative, [and] practical application[]" to "effectuate a statutory program" 388 by looking at inputs such as:

technical assessment of on-the-ground facts; expert predictions; the policy views of administrators and staff; input from the public, especially from affected interests; political influence and control from the White House and the current Congress; the agency's own understanding of the statutory provisions in its organic act; and the practical needs of the bureaucracy to manage and enforce a statutory program. ${ }^{389}$

EMORY L.J. 1469, 1473-77 (2015) (arguing for increased reliance on rulemaking to improve the NLRB's stability, consistency, and lawmaking). There are of course disadvantages to rulemaking as well, as it involves more time and cost and offers less flexibility to respond to changing circumstances in the near term. See Acosta, supra, at 357-58 (acknowledging cost and difficulty that the NLRB could initially face in a transition to rulemaking).

383. See Strauss, supra note 96, at 329 (observing that "agency officials are concededly political" and therefore differ from judges in important respects).

384. Mashaw, Between Facts and Norms, supra note 4, at 522; see also Kevin M. Stack, Agency Statutory Interpretation and Policymaking Form, 2009 MICH. ST. L. REV. 225, 226 (2009) (“[A]n agency's approach to statutory interpretation is in part a function of the policymaking from through which it acts.").

385. Stack, supra note 384 , at 238.

386. For instance, the Board so frequently changes who qualifies as an "employee" under the NLRA that no doubt the appellate courts find it difficult to keep up. See supra Part II.C.2.b.

387. See Acosta, supra note 382, at 359 (arguing that rulemaking would more "clearly delineate" the NLRB's scope of authority). But see Tuck, supra note 150 , at 1121 (proposing that a policy statement on the definition of "employee" is a more feasible alternative to rulemaking).

388. Foote, supra note 355 , at 681 .

389. Id. 
Using rulemaking would also bring the NLRB in line with how most other administrative agencies conduct their business, 390 and offer a chance to use its expertise to collect and analyze information to foster best practices. ${ }^{391}$ Appellate courts may be more likely to defer to the rulemaking process because rulemaking by necessity is more inclusive. ${ }^{392}$ Engaging in statutory interpretation through rulemaking might also lead to greater national uniformity ${ }^{393}$ and might provide more notice to litigants of legal rules, ensuring better compliance. ${ }^{394}$ Moreover, rulemaking would help Congress better monitor agencies since it would be easier to raise the "fire alarm" when an agency departs from political preferences. ${ }^{395}$ Of course, engaging in rulemaking to interpret statutes may alter the way an agency reviews statutes, given that agencies may interpret a statute more aggressively if it feels confident that the appellate court will apply Chevron deference. ${ }^{396}$ But engaging in rulemaking may reduce the propensity of the Board to act like judges "balancing rights rather than [like] policy analysts studying social and economic regulatory problems." 397 This greater degree of certainty may give both litigants and agencies more comfort. ${ }^{398}$

390. Acosta, supra note 382, at 352.

391. See supra Part III.B (proposing reforms to leverage NLRB expertise).

392. Garden, supra note 382, at 1475.

393. Cf. Peter L. Strauss, One Hundred Fifty Cases per Year: Some Implications of the Supreme Court's Limited Resources for Judicial Review of Agency Action, 87 CoLUM. L. REV. 1093, 1112 (1987) (noting the value of national uniformity in agency statutory interpretation).

394. See Richard E. Levy \& Sidney A. Shapiro, Administrative Procedure and the Decline of the Trial, 51 U. KAN. L. REV. 473, 480-81 (2003) (outlining advantages of rulemaking over adjudication, including clarity and compliance).

395. Lisa Schultz Bressman, Reclaiming the Legal Fiction of Congressional Delegation, 97 VA. L. REV. 2009, 2044 (2011).

396. Barnett \& Walker, supra note 60, at 43 (finding that agencies interpreting statutes through adjudication win more than agencies interpreting statutes through rulemaking under Chevron); Walker, Inside Agency, supra note 5, at 1063 (noting study found that 40\% of agency rule drafters thought that the agency would be "more aggressive" in interpreting a statute if they felt Chevron applies).

397. Fisk \& Malamud, supra note 20, at 2019.

398. Barnett \& Walker, supra note 60 , at 72 (noting that giving more guidance to courts in interpreting statutes would be a "comforting swaddling blanket rather than handcuffs"). 


\section{CONCLUSION}

Formed during the New Deal, the NLRB of 2019 is at its heart a policymaking body behaving like a court. There are several problems with this approach. The Board's unique institutional position in the separation of powers system requires it to interpret statutes differently than a court might, taking into consideration the consequences of policy as opposed to simply engaging in a text-based analysis of the statute backed up by legislative history. The Board should adapt its techniques of statutory interpretation to fully embrace its role as a policymaking body to better guide judicial review. It can do this by making its policymaking more explicit and grounding its decisions in social science data and substantive labor law principles. It can also use the rulemaking process to make its statutory interpretation more transparent. Doing so would allow agencies to better balance the aims of achieving stability, coherence, and democratic accountability in statutory interpretation. 